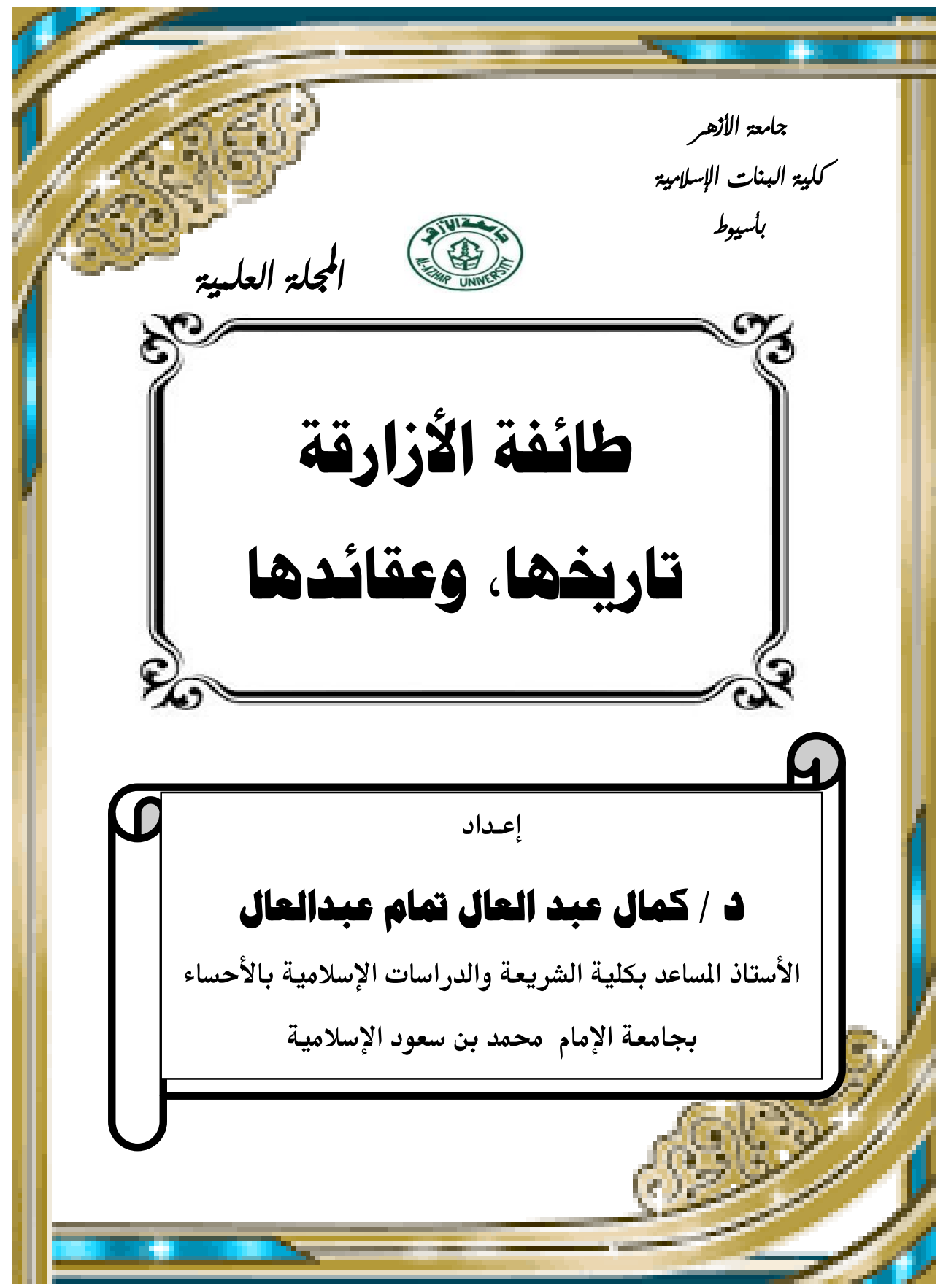




\section{مانم البمث}

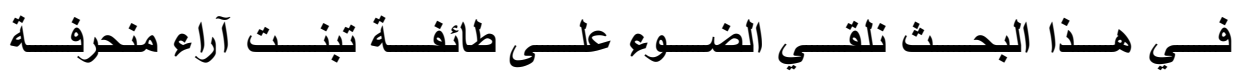

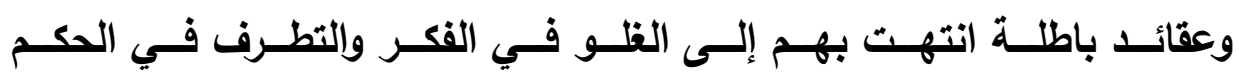

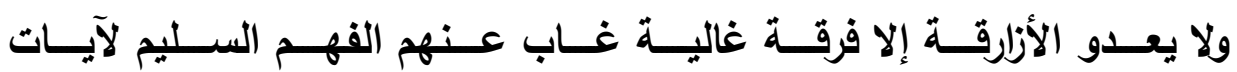

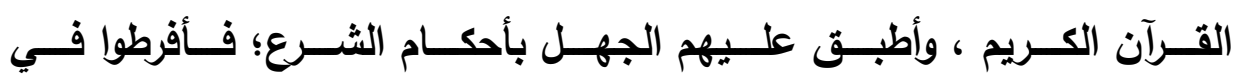
التكفير، وإخراج الناس من الدين. ويهدف البحث إلى :

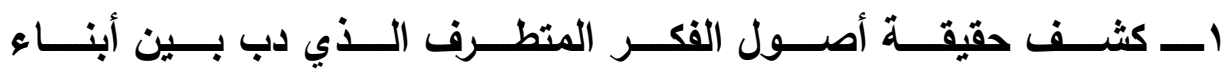
الأمة منذ عهد ظهور الخوارج وحتى عصرنا الحاضر .

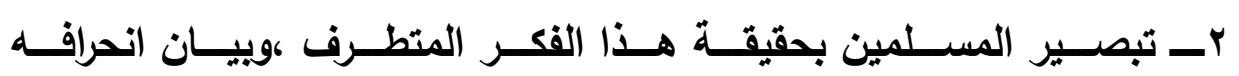

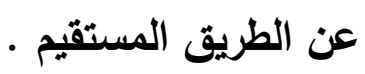

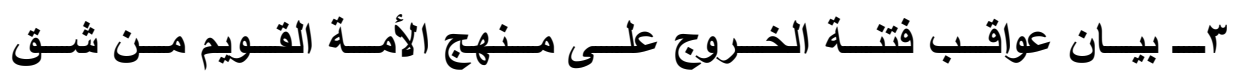
صف المسلمين ، واستباحة دمائهم ، والخروج بعقائد فاسدة

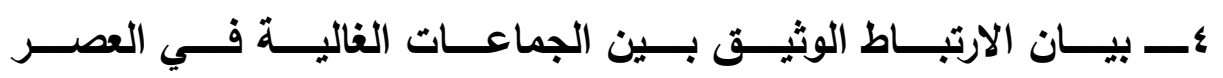

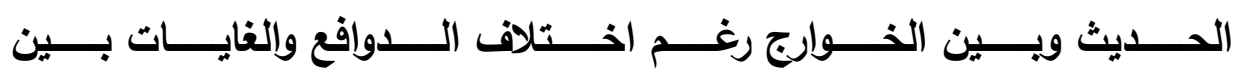
الفريقين - الفيان

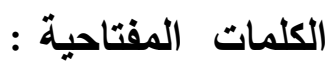
الأزارقة ، التكفير، نافع بن الأزرق ، الجماعات ، الاماء .

\section{Research Summary}

In this research, we shed light on a sect that adopted deviant opinions and false beliefs that led them to exaggeration in thought and extremism in

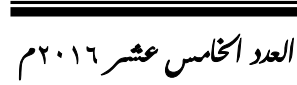

مجليكليي البنات الإساميي- جامع: الأهر- فر أسيوط 
government,

The Azarqas are only a Ghalia band who have lost the proper understanding of the verses of the Quran, and the ignorance of the provisions of Islam has been applied to them.

The research aims to:

1 revealed the truth of the origins of extremist thought that has been among the nation since the era of the emergence of the Kharijites and even our present

2 to enlighten the Muslims about the truth of this extremist ideology, and to show its deviation from the straight path.

3 - Statement of the consequences of the fitnah of sedition on the approach of the righteous nation of dividing the Muslims, and shedding their blood, and coming out with corrupt beliefs.

4 - A statement of the close link between the expensive groups in the modern era and the Kharijites despite the different motives and goals between the two groups. key words :

The Azarqas, the Atonement, the Nafie the Blue, the groups, the blood 


\section{المقدمة}

إن الحمد لله نحمده ،ونستعينه ،ونستففره ،ونعوذ بالله من شرور أنفسنا ،ومن

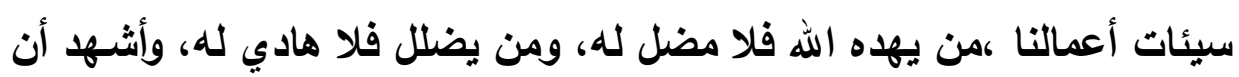

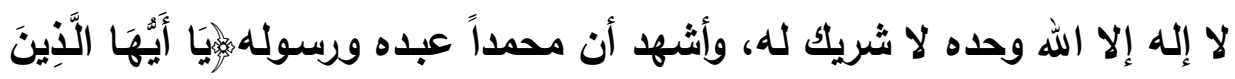

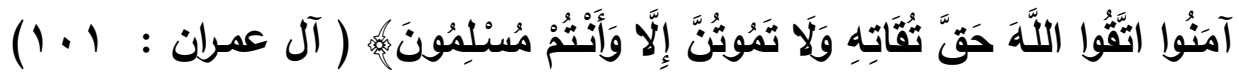

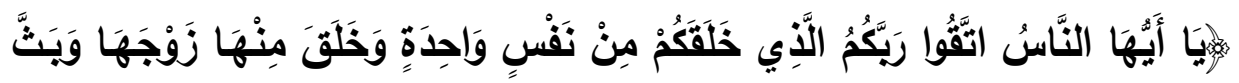

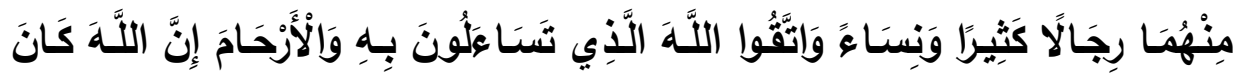

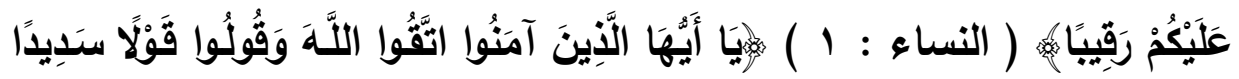

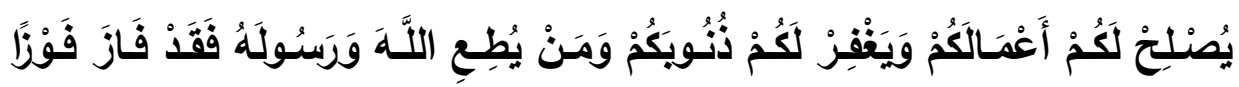

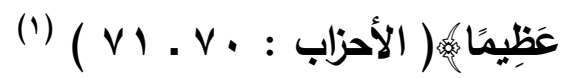

الأزارقة هي إحدى فرق الخوارج التي خرجت في النصف الثاني من القرن الأول

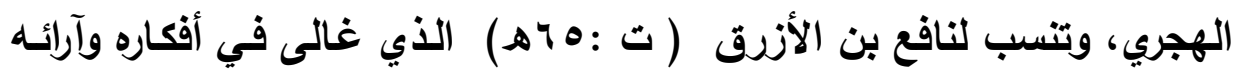

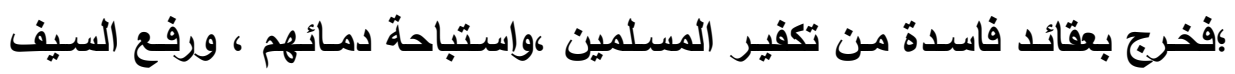

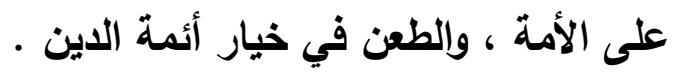

ولا يعدو الأزارقة إلا فرقة غالية غاب عنهم الفهم السليم لآيات القزآن الكريم،

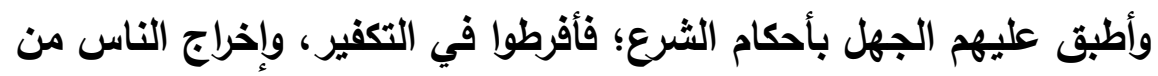

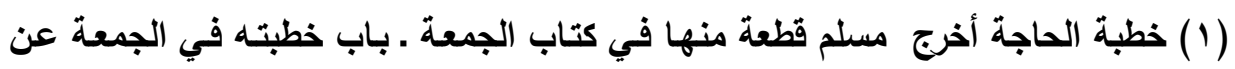

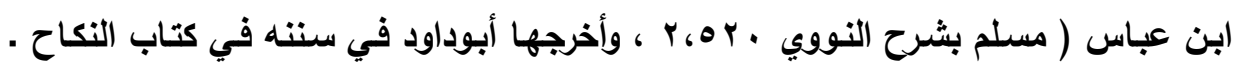

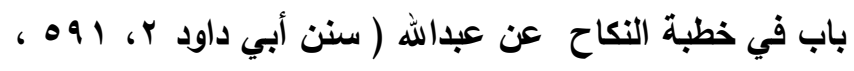
و الترمذي في سنته في كتاب النكاح ـ باب في خطبة النكاح عن ابن عباس ( سنن الترمذي .

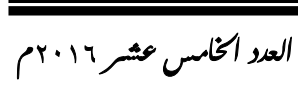
مجليكليي البنات الإساليي- جامعء الأهر- فع أسيوط (4901) 
وقد تبنى الأزارقة آراء منحرفة وعقائد باطلة انتهت بهم إلى الغلو في الفكر وإلتطرف في الحكم ،والذي جمعهم من الدين أثياء :

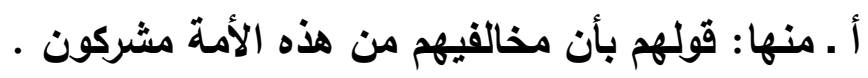

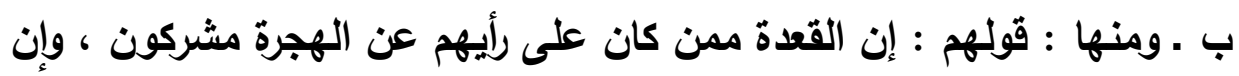
كانوا على رأيهم . ج ـ ومنها :أنهم أوجبوا امتحان من قصد عسكرهم إذا ادعى أنه منهم .

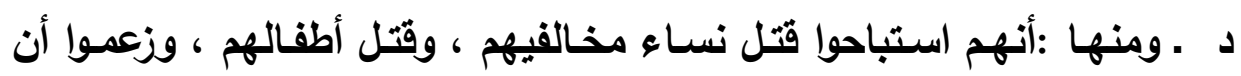

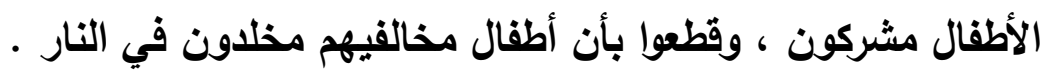

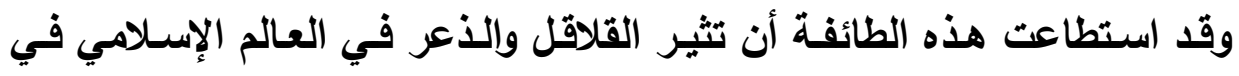

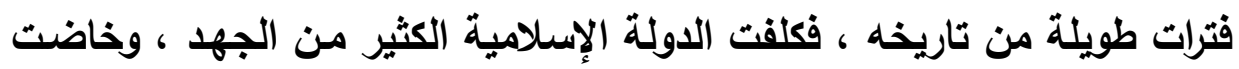

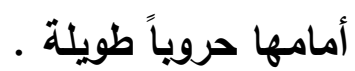
وترجع خطورة الأزارقة إلى تأثر الجماعات الغالية والمتطرفة في عصرنا الحاضر

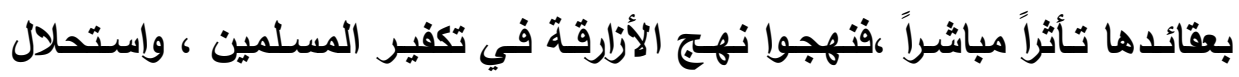

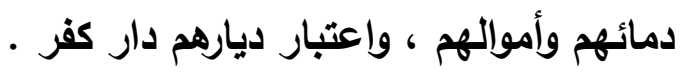

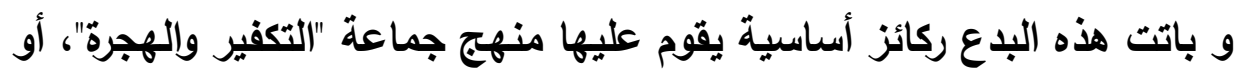
" تنظيم القاعدة"، أو "تنظيم داعش"، ومـا يقومسون بـه في العقود الأخيرة مـن أفعـال القتل واللذبح ، ومــا

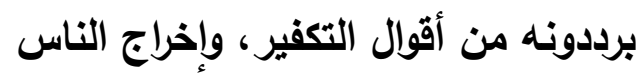

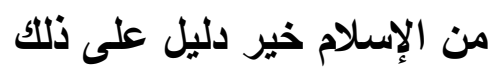

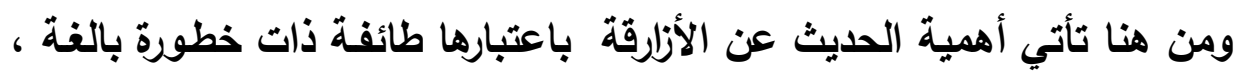

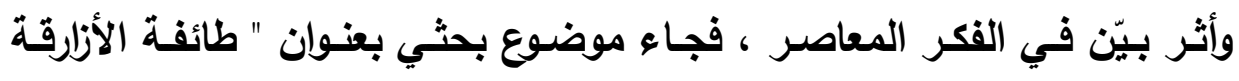

مجليكليت البنات الإسلميت- جامعة الأهر- فع أسيوط




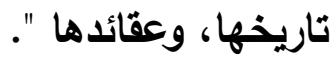

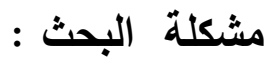
ويتحدد موضوع البحث في السؤال الرئيس التالي: ما الحقيقة التاريخية والفكرية لطائفة الأزارقة ؟ ، ويتفرع من هذا السؤال الأسئلة الفرعية التالية: ا ـ ما ملابسات نشأتها ومن أشهر رجالها ؟ r. ما أهم آرائهم الغالية في العقيدة ؟ r. وما أثر طائفة الأزارقة في الجماعات المعاصرة ؟ أسباب اختيار الموضوع : إن من أهم ما دفعني للخوض في خضم هذا البحث ما يلي اـ أن فرقة الأزارقة الخوارج هي الوجها الأكثر غلواً، والأشد تطرفاً في مسألة - التكفيز r. خطورة الآراء والأفكار التي اعتقدها الأزارقة ؛ إذ أنها من أكثر الآراء اتحرافاً

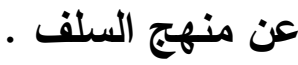
rــ الوقوف على مدى التأثير والتأثر الفكري للغـلاة في العصر الحديث بآراء وأفكار الأزارقة ، وتطبيقها على المسلمين اليوم. أهداف البحث : وتتحدد أهمية البحث في :

اـ كثـف حقيةـة أصـول القكر المتطرف الذي دب بين أبنـاء الأمـة منــ عهد ظهور الخوارج وحتى عصرنا الحاضر • rـ تبصير المسـمين بحقيقة هذا الفكر المتطرف،ويبيان انحرافـه عن الطريـق

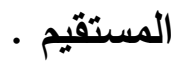
r ـ بيان عواقب فتنة الخروج على منهج الأمة القويم من شق صف المسلمين

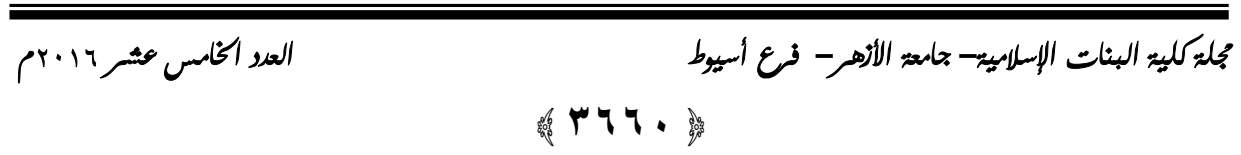


، واستباحة دمائهم .، والخروج بعقائد فاسدة . ء. بيان الارتباط الوثيق بين الجماعات الغالية في العصر الحديث وينين الخوارج

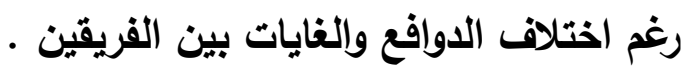
منهج البحث : انتظت منهجية البحث على الأساسيين : التاريخي ، و الوصفي التحليلي ، " في هيئة استرجاع صورة الماضي

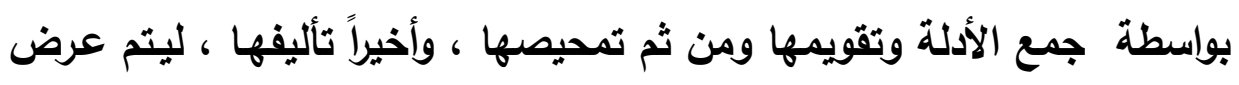

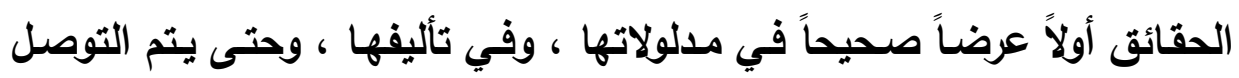

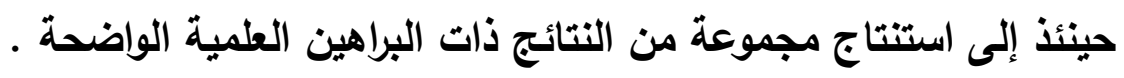

\section{فطة البمث :}

جاء التكوين العلمي للبحث في مقدمة، و أربعة مباحث ، وخاتمة على النحو التالي : المقدمة : وفيها أسباب اختياري لهذا الموضوع، وأهميته، ومنهج البحث، وخطته . المبحث الأول : الخلفية التاريخية للأنارقة ، ويشتمل على مطلبين :

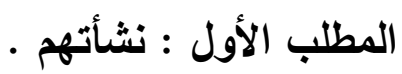

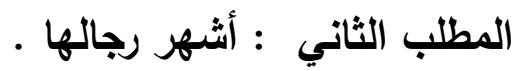

المبحث الثاني : عقيدة التكفير عندالألارقة.، ويثتمل على ثلاثة مطالب : المطلب الأول : تكفيرهم لأمير المؤمنين علي بن طالب ـ رضي الله عنه .

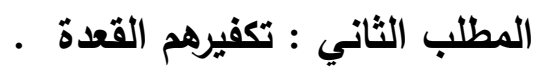
المطلب الثالث : تكفيرهم مرتكب الكبيرة. 
المبحث الثالث : معتقداتهم وآراؤهم الفكرية ، ويشتمل على عدة مطالب : المطلب الأول : حكمه بأن أطفال المشركين في النار مع آبائهم . المطلب الثاني :قولهم إن التقية غير جائزة في قول ولا عمل . المطلب الثالث : إباحتهم قتل أطفال المخالفين ، والنسوان . المطلب الرابع :إسقاطهم الرجم عن الزاني .

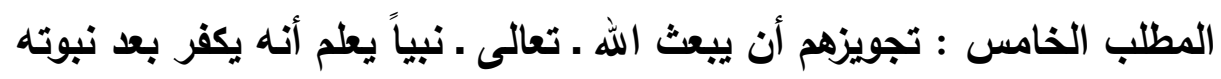
المبحث الرابع : المبحث الرابع : أثر طائفة الأزارقة في الجماعات المعاصرة المطلب الأول : التكفير •

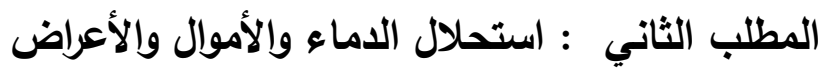
الخاتمة : وذكرت فيها أهم النتائج والتتوصيات ل الأولال 


\section{المبمث الأول}

\section{الخلفية التاريخية للأزارقة}

الأزارقة هي إحدى فرق الخوارج الغالية ، خرجت في النصف الثاني من القرن

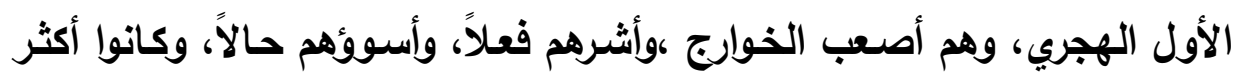

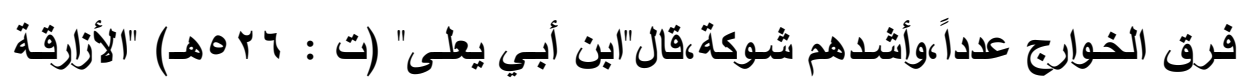

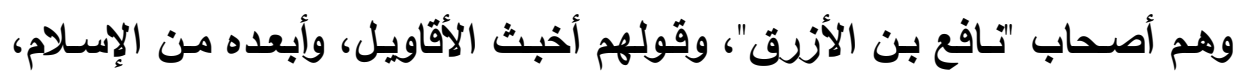

والسنة . "(1)

\section{الإطباب الأول}

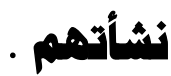

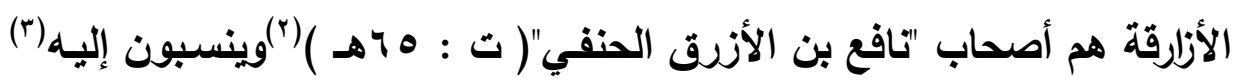

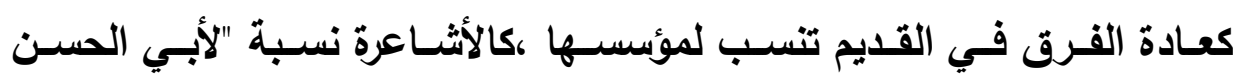

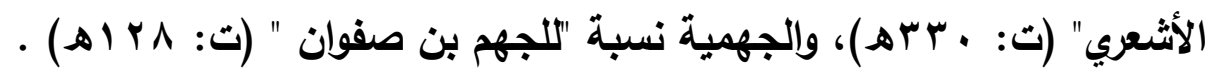

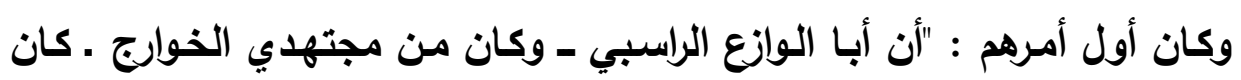

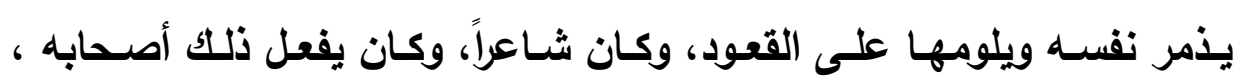

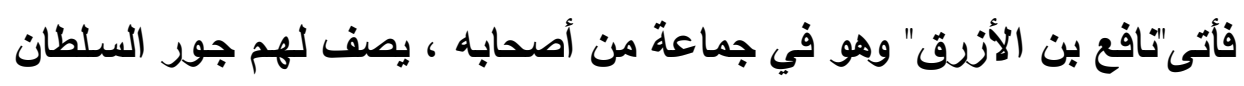

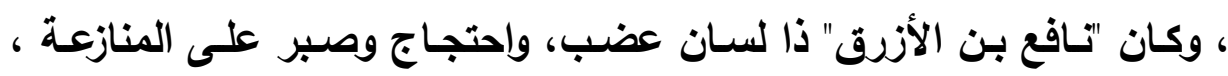

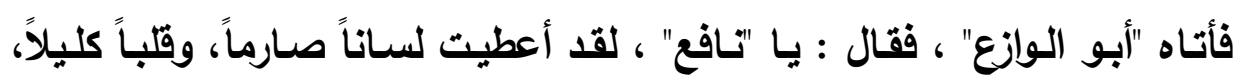

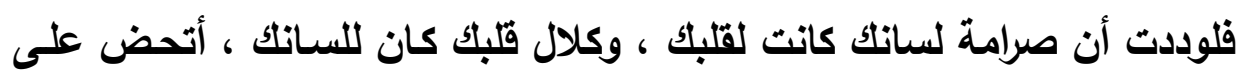

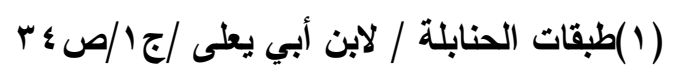

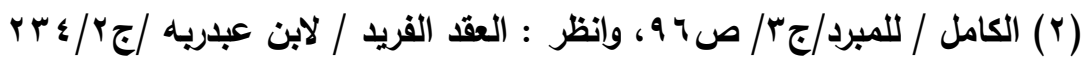

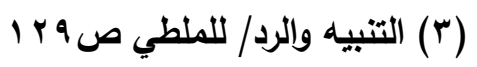

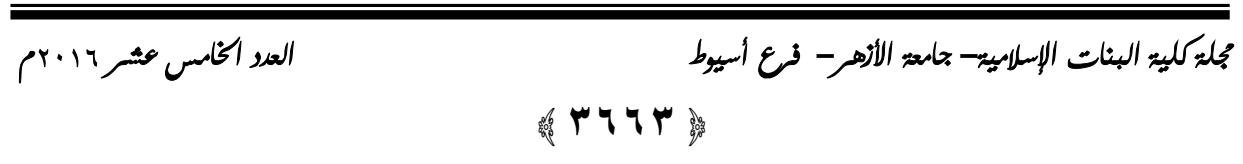


الحق وتقعد عنه ، وتقبح الباطل وتقيم عليه؟ فقال : يا "أبا الوازع" ، إنما أنتظر

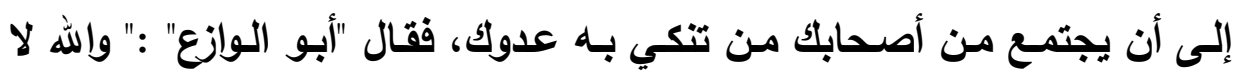

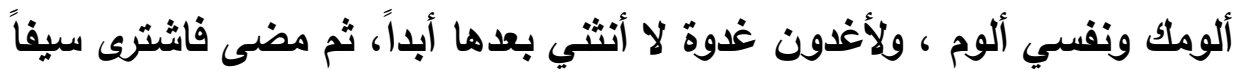

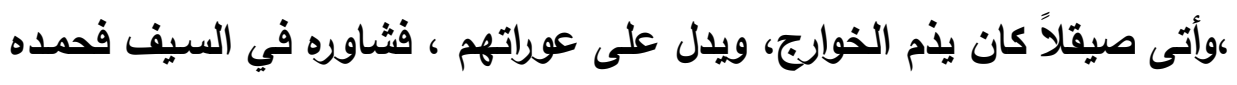

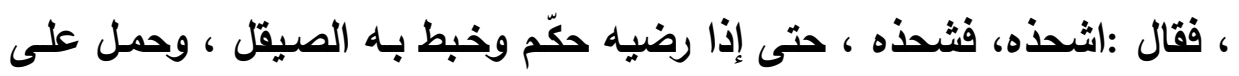

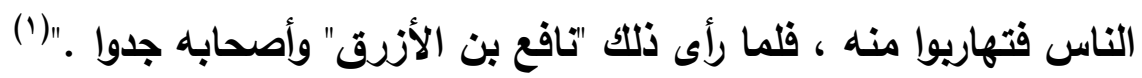

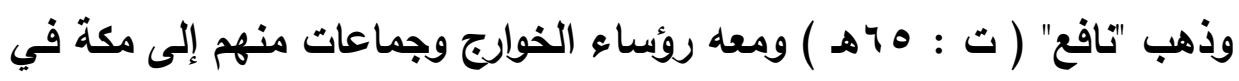

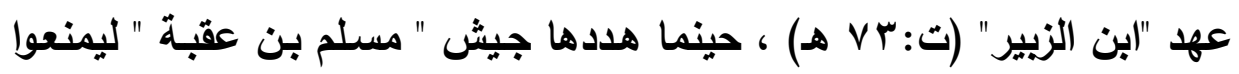

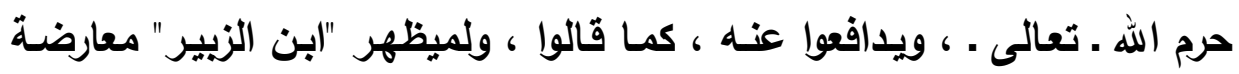

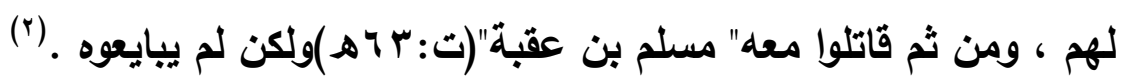

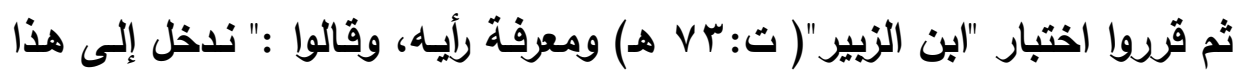

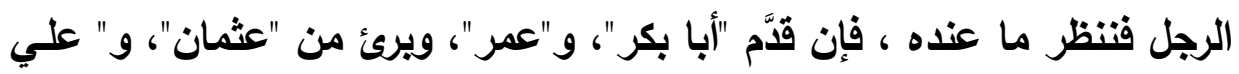

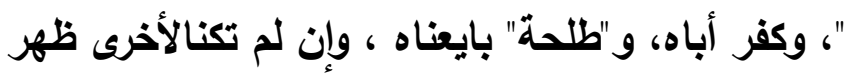

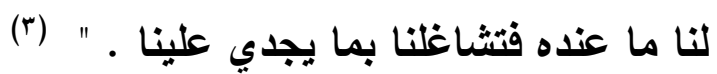

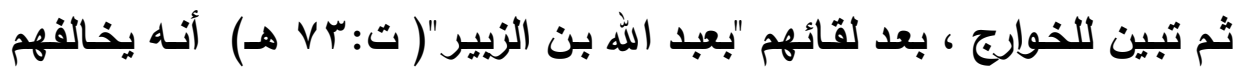

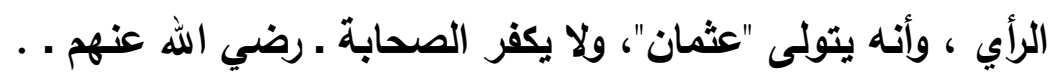

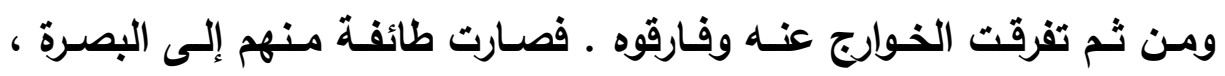

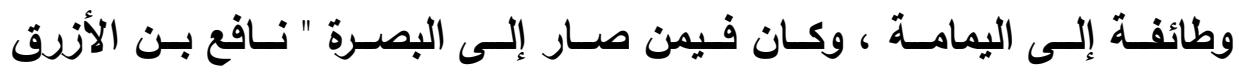

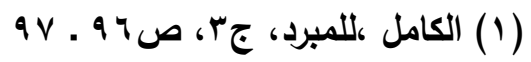

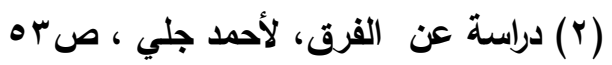

$$
\begin{aligned}
& 9 \text { V }
\end{aligned}
$$

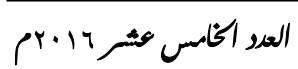

مجليكليي: البنات الإسلميت- جامعء الأهر- فع أسيوط 
الحنفي"(ت : 70 هـ ) ، ورئيسهم " "حسان بن يخلج " ، فلما صاروا إلى البصرة

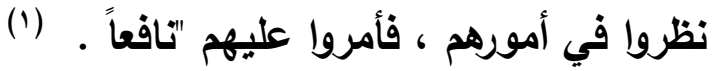
ويدأ "تافع"( ت : ه 7هـ ) يدعو إلى أرائه المتطرفة، وأفكاره الضالة ، فكتب إلى هـ "عبدالله بن الزيبير"( ت: Vr هـ) يقول : " أما بعد ، فإني أحذرك من الله :يوم تجد كل نفس ما عملت من خير محضراً ومـا عملت من سوء تود لو أن بينها

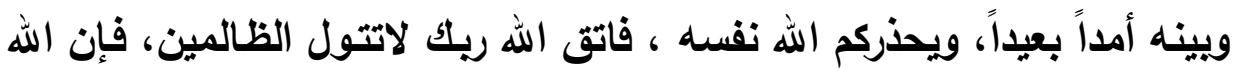

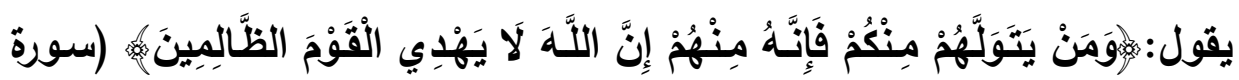
(المائدة : (0)

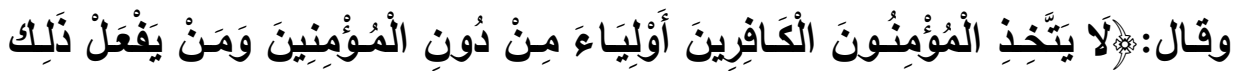

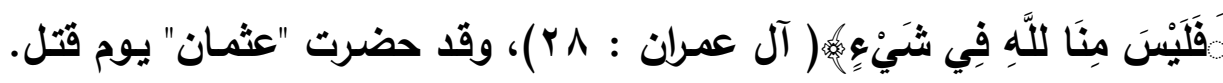
فلعمري لئن كان قتل مظلوماً لقد كفر قاتلوه وخاذلوه، ولئن كان قاتلوه مهتدين . وإنهم لمهتدون ـ لقد كفر من تولّاه ونصره. ولقد علمت أنّ أباك و "طلحة" و"عليّاً

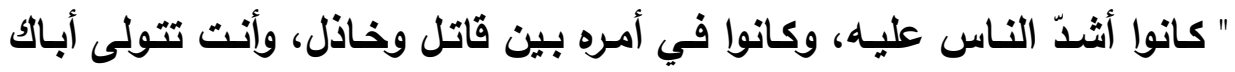
و"طلحة" و"عثمان"، فكيف ولاية قاتل متعمّد ومقتول في دين واحد؟ ولقد ولي "علي" بعده فنفى الثَّبهات، وأقتام الحدود، وأجرى الأحكام مجاريها، وأعطى الأمور حقّها فيما عليه وله، فبايعه أبوك و"طلحة"، ثم خلعا بيعته ظالمين لـه، وإن القول فيك وفيهما لكما قال "ابن عباس"( ت: 11 هـ) . رحمهالله . : إن يكن عليّ في وقت معصيتكم ومحاريتكم لله كان مؤمنا لقد كفرتم بقتال المؤمنين

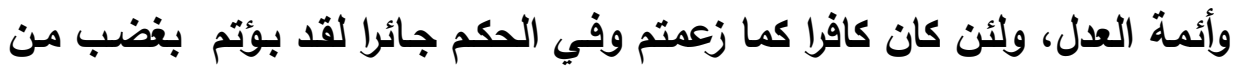
الله لقراركم من الزحف، ولقد كنت لـه عدوّا، ولسيرته عائبا، فكيف توليته بعد

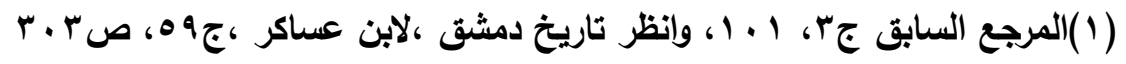

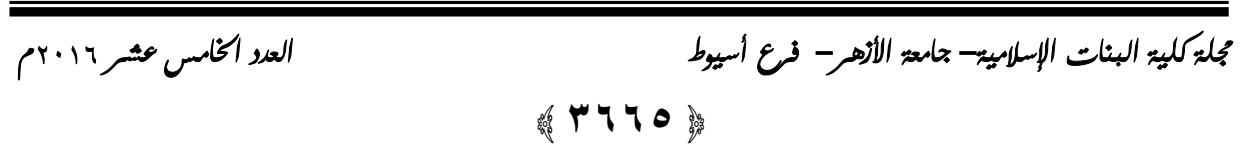


موته." (') (1)

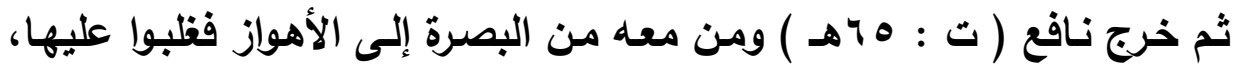

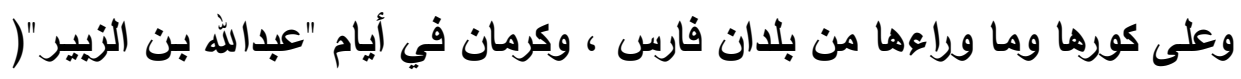

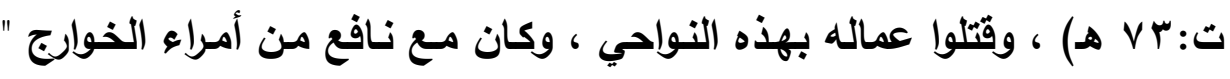

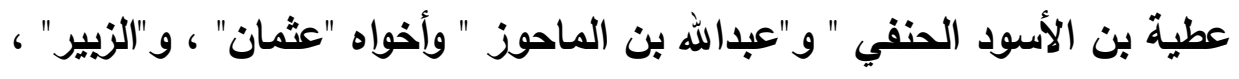

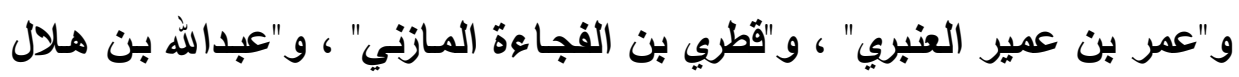

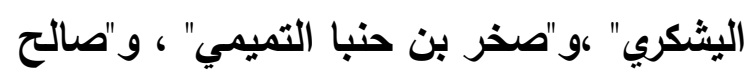

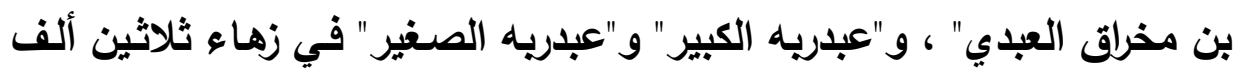

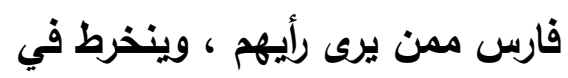

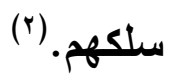
والذي جمعهم من الدين أثياء :

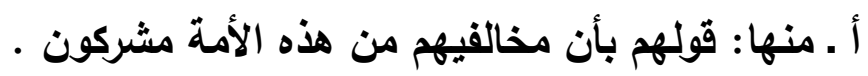

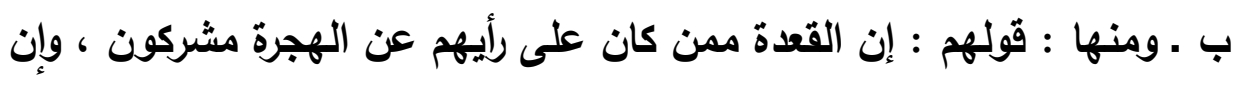
كانوا على رأيهم . ج ـ ومنها :أنهم أوجبوا امتحان من قصد عسكرهم إذا ادعى أنه منهم .

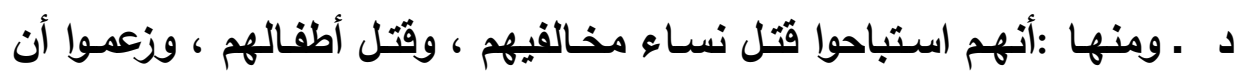

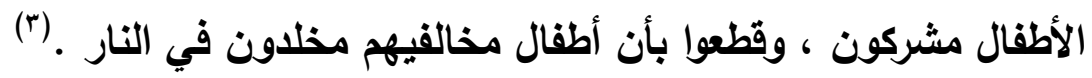

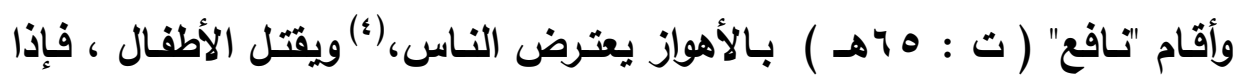

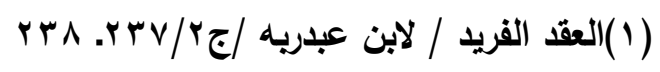

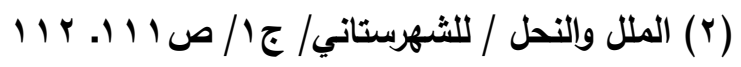

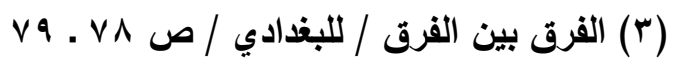

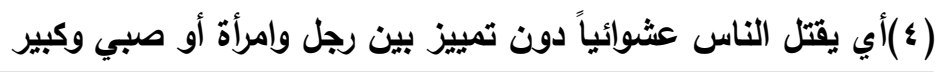

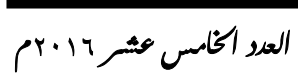

مجليكليي البنات الإساليي- جامعء الأهر- فع أسيوط 
أجيب إلـى المقالـة جبـا الخـراج ، وفنشـا عمالـه فـي الســواد ؛ وأرجـع "ابـن

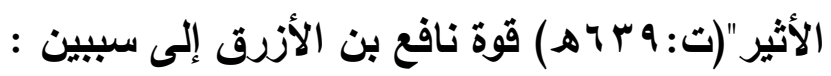

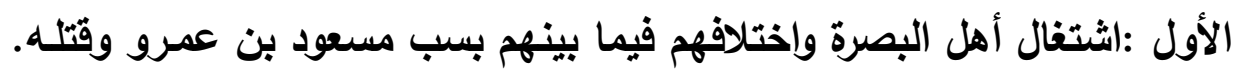

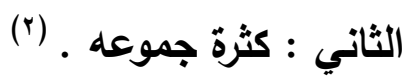

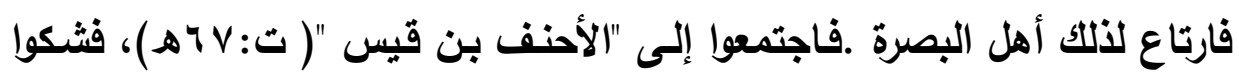
ذلك إليه ، وقالوا :" ليس بينتا وبين العدو إلا ليتان ، وسيرتهم ما ترى "، فقال

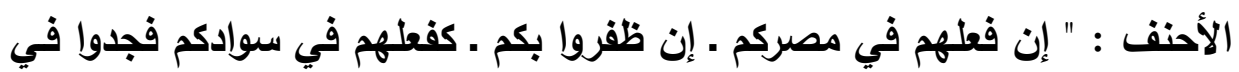

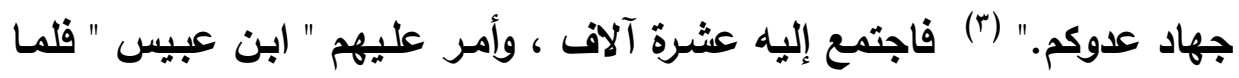

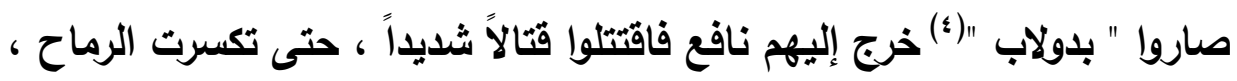

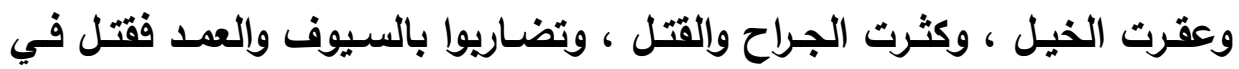

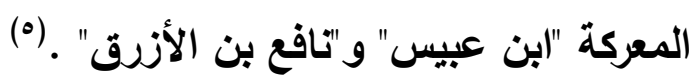

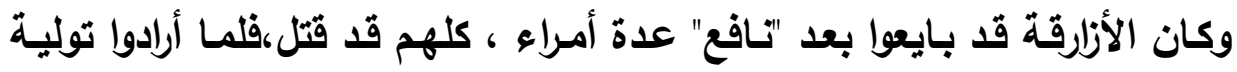

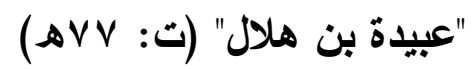
قال : " أدلكم على من هو خير لكم مني ، من بـ بطاعن في قبل ، ويحمي في دبر ، عليكم قطري بن الفجاءة

(1) مسعود بن عمرو زعيم الأزد ، وثُبت عليه الحرورية فقتلوه انظر تاريخ الإسلام وَوَفيات

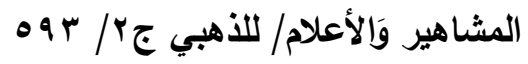

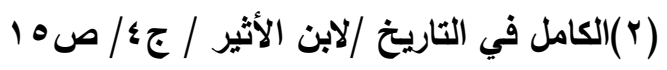

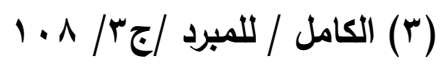

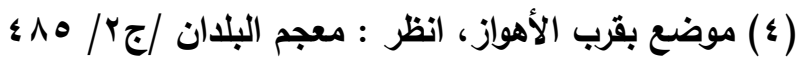

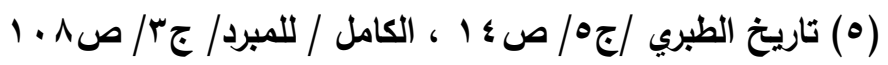

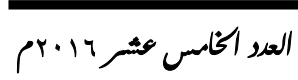

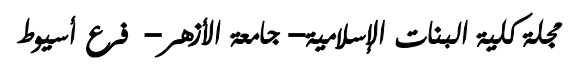
(4) Mับ 


$$
\text { المزني (ت: Vه } 9 \text { هـ ) (')فبايعوه وسموه أمير المؤمنين . }
$$

وتولى قتال الأنارقة من قبل "عبدالله بن الزيير"( ت: V هـ)"المهلب بن أبي

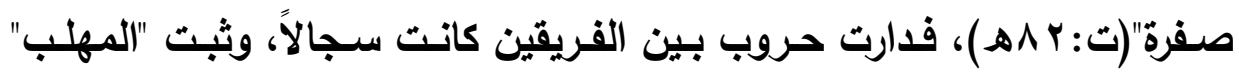
وينوه وأتباعهم على قتال الأزارقة تسع عشرة سنة، بعضها في أيام "عبدالله بن

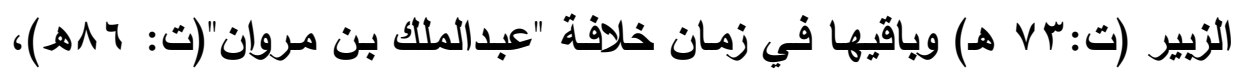
وولاية"الحجاج"(ت:0 9 هـ) على العرلق • وقرر "الحجاج"'المهلب" على حرب الأزارقة فدامت الحرب في تلك السنين بين

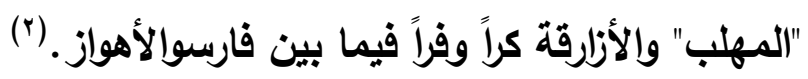

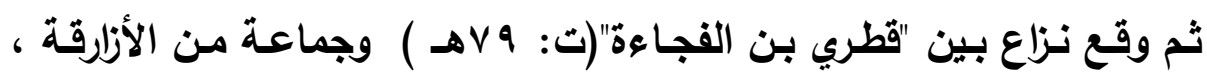

وأدى النزاع إلى اتهامهم له بالكفر واستتابته . واشتعل الخلاف بين الأزارقة حتى اقتتلوا فيما بينهم ، وتفرق جيشهم ، فسار عبدريه الكبير( ت:هV) إلى واد "جيرفت كرمان " في سبعة آلاف رجل ، بينما ذهب "عبدربـه الصغير"(ت: VV هـ) إلى كرمـان في أربعة آلاف ، أمـا " قطري " فقد بقي في بضعة عشر ألف رجل بفارس (؛ثم سـار إلى طبرستان مـع جماعة وغلب عليها، ولكن لحقت به جيوش الأمويين وأوقعت به الهزيمة، وانتهى الأمر

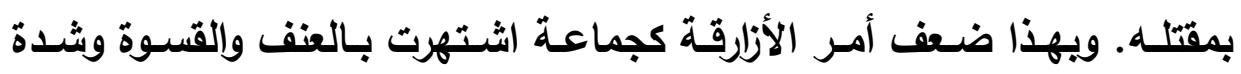
البطش والبأس، وامتلأ تاريخهم بالدماء والقتل والنهب والسلب، وأكدوا كل هذه

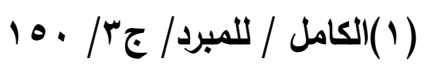

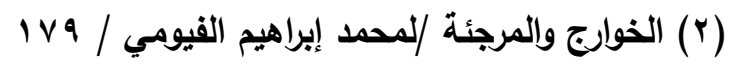

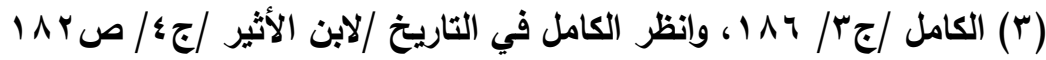

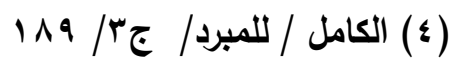

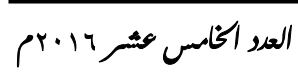$$
\text { مجلةكليت البنات الإسلميت- جامع: الأهر- فئس أسيوط }
$$ 
الصفات في مبادئهم وتعاليمهم التي تبنوها، وحاولوا بكل عنف تطبيقها ـ (1)

\section{الإناب الثماني \\ أشمدر رجانها}

ا. نافع بن الأزرق ( ت : 10 هـ ) رأس الأزارقة، وإليه نسبتهم ، اسمه نافع بن

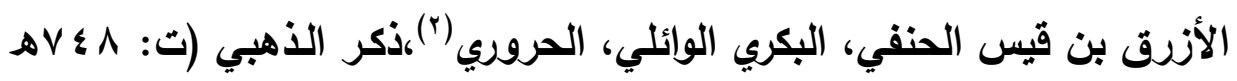

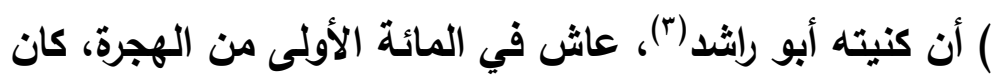

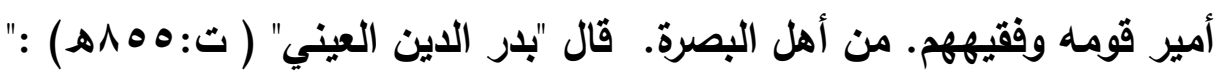
نافع بن الأزرق، وهو من الدول بن حنيفة، ولا عقب له"(4)،وقتل يوم (دولاب)

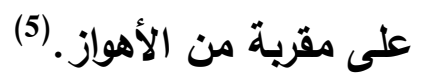
وكان قا صحب في أول أمره "(بن عباس"(ت: 4 هـ) . رضسي الله عنه ـ يسأله ويعارضه، فقد وجه "لابن عباس"( ت: 1 هـ) أسئلة عن معنى أكثر من مائتي كلمة صعبة في القرآن، فأجاب عنها ووضحها بشواهد من الثعر القديم، حتى ونى

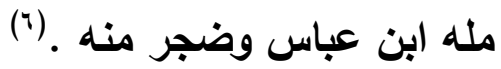
ومن جملة ما وقع سؤاله عنهما يلي :

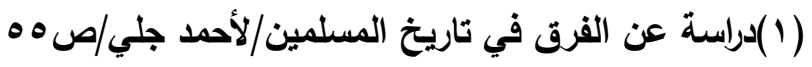

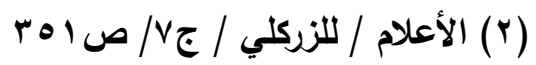

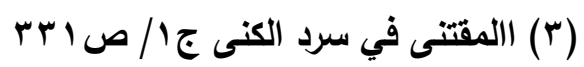

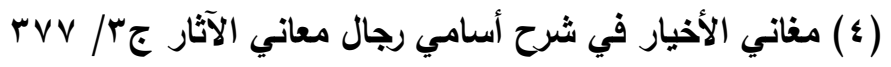

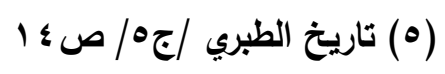

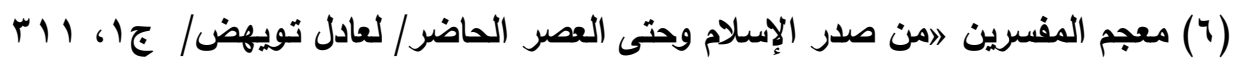

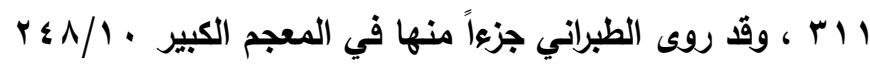

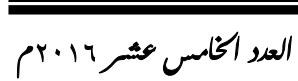

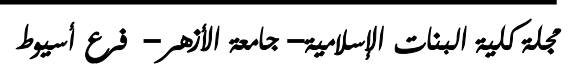




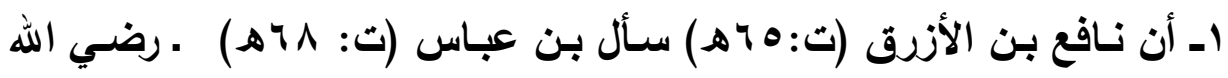

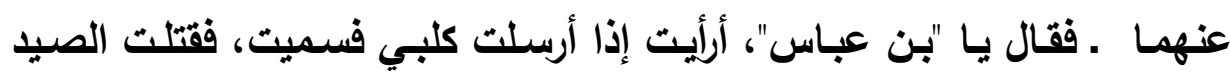
آكله؟

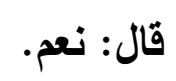

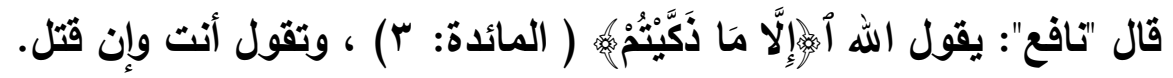

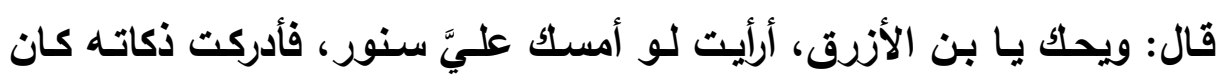

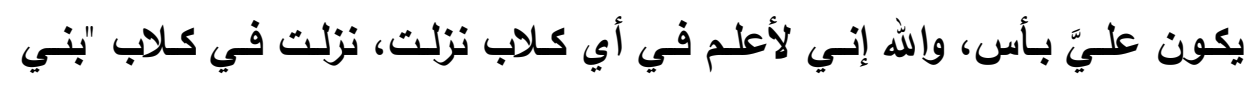

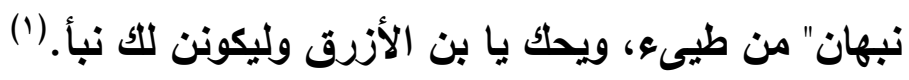

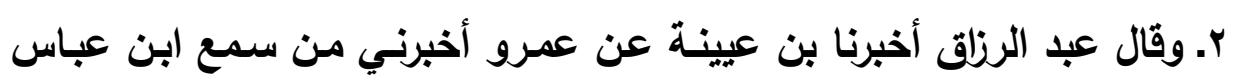

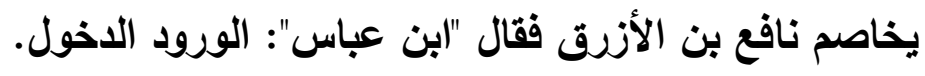

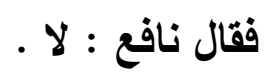

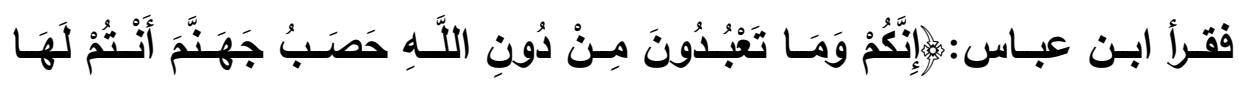

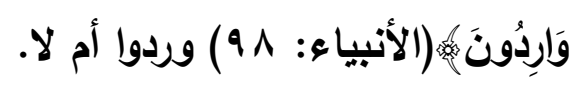

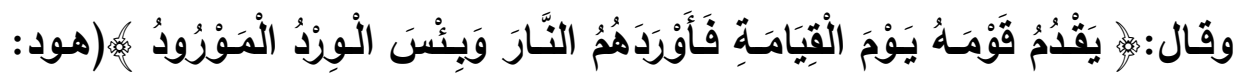

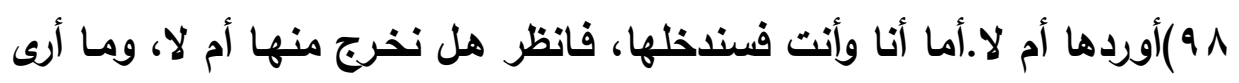

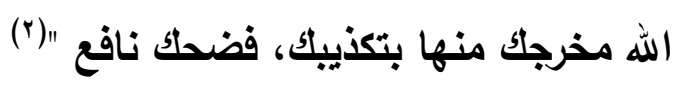

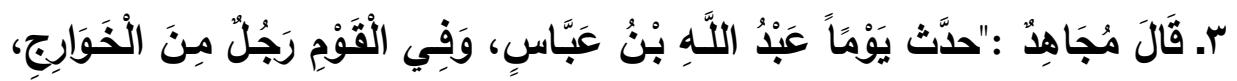

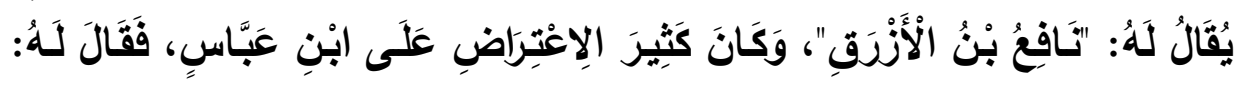

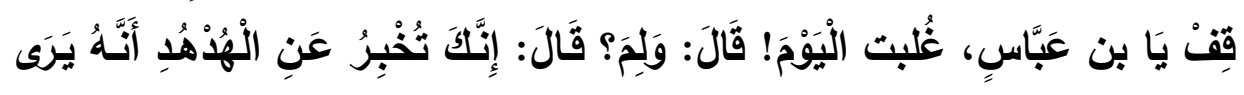

$$
\begin{aligned}
& \text { (1) رواه البيهقي فيالسنن الكبرى /ح رقم . 1140 (1) }
\end{aligned}
$$

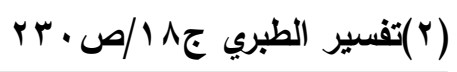

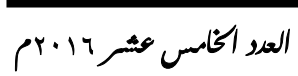

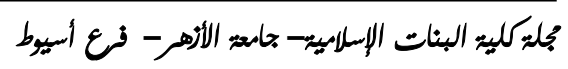




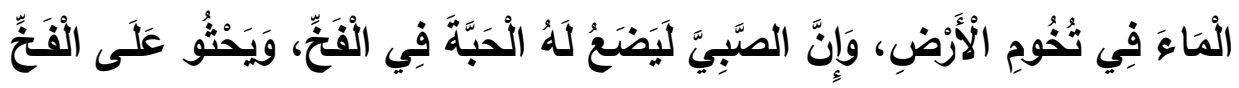

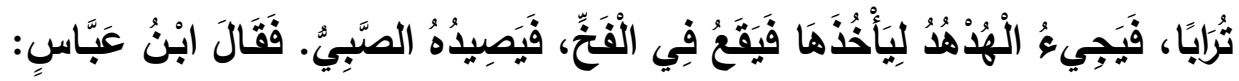

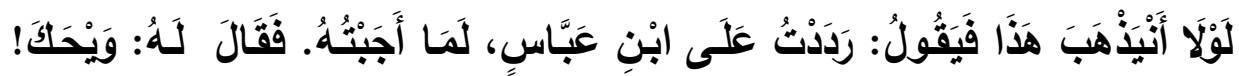

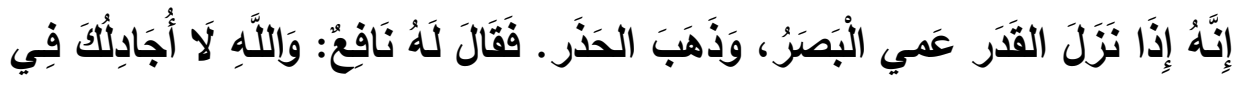

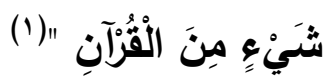

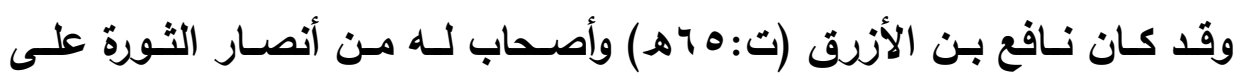

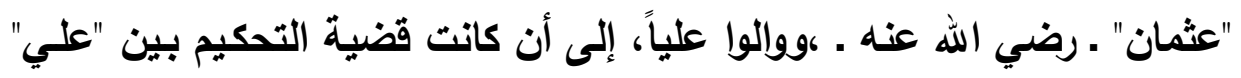

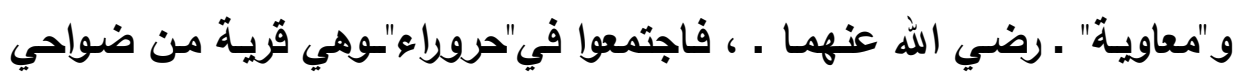

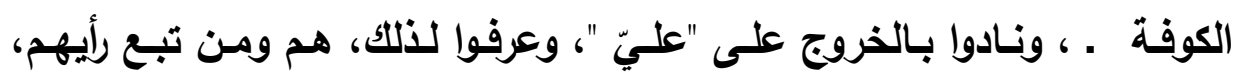

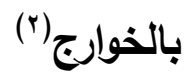

وأظهر نـافع (ت: 10 هـ) آراءه الضـالة، وجهر ببعض أفكاره الغاليـة كتكفيره

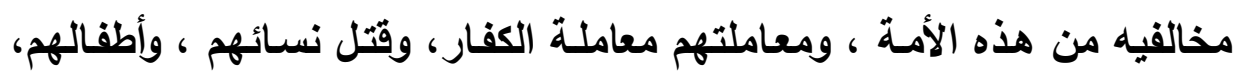

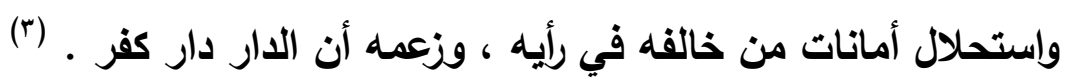

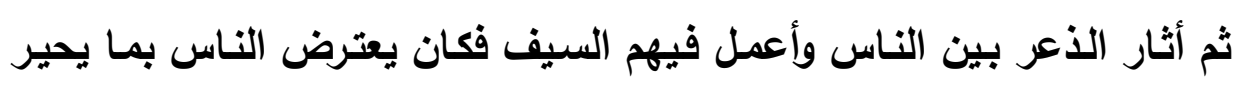

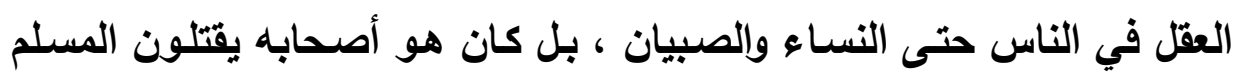

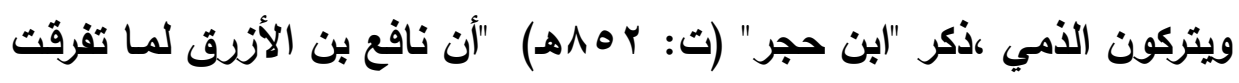

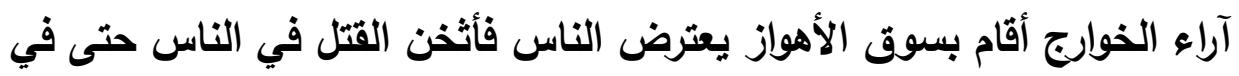

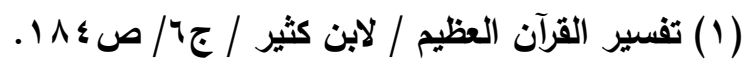

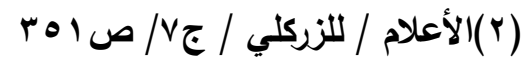

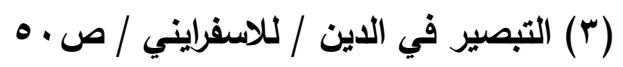

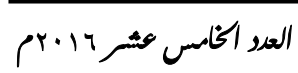

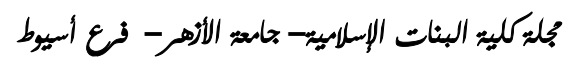




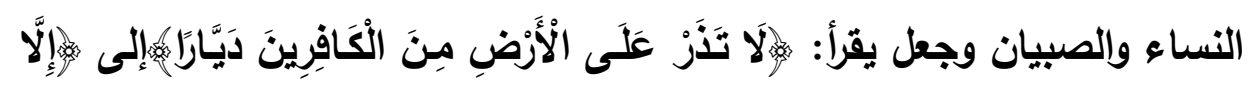

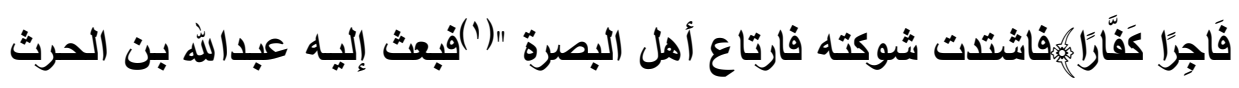

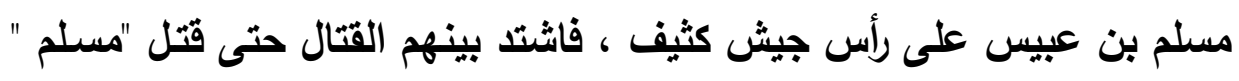

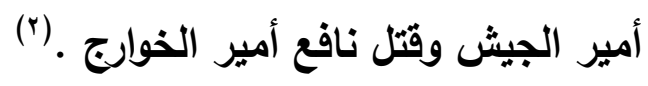

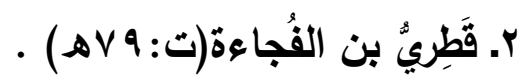

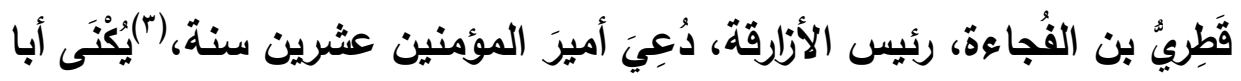

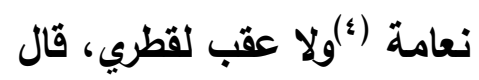

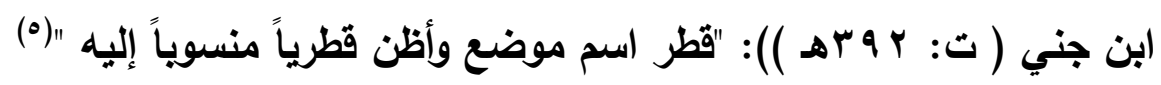
وقد قيل: إن قولهم قطري ليس باسم له، ولكنه نسبة إلى موضسع بين البحرين وعمان، وهو اسم بلا كان منه

أبو نعامة المذكور، فنسب إليه، وقيل إنه هو قصبة عمان، والقصبة هي كرسي الكورة. الكو نعائة المان)

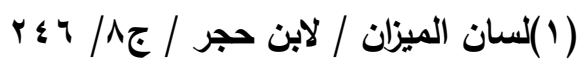

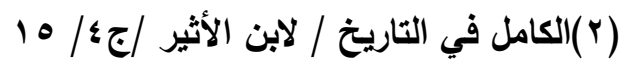

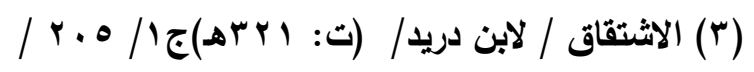

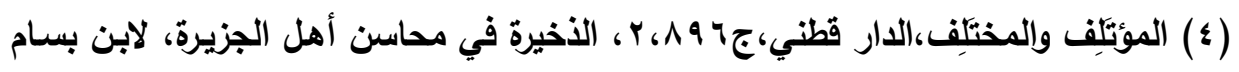
(4)

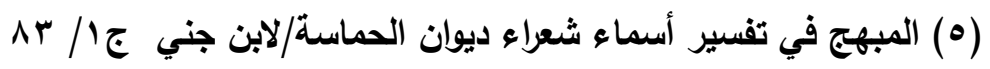

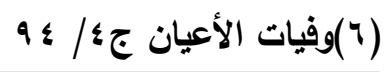

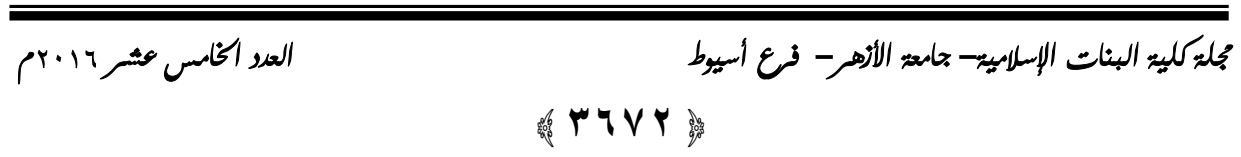


وقال ابنُ الكَلْبي:" قطري بن الفُجَاءة واسم الفُجَاءة جَعُونَة بن مازن بن يَزِيد بن

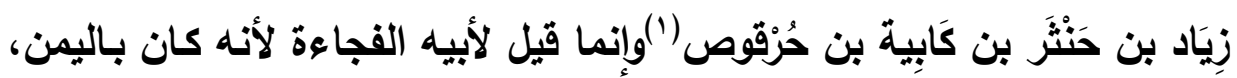

فقدم على أهله فجاءة، فسمي به ويقي عليه. قال صاحب "سنا المهتدي" في وصفه: " كان طامة كبرى، وصاعقة من صواعق عي به الانيا في الشجاعة والقوة " (r)

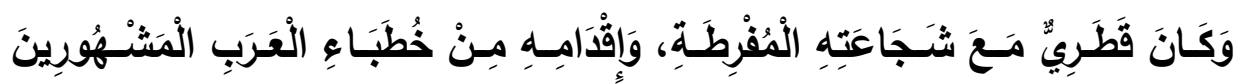

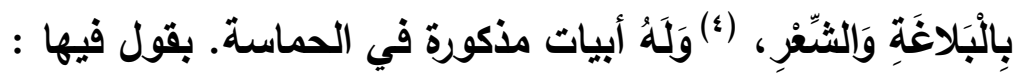

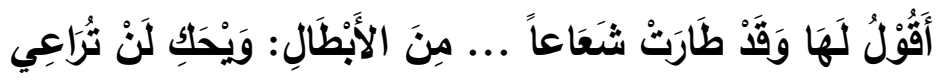

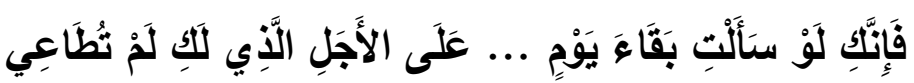

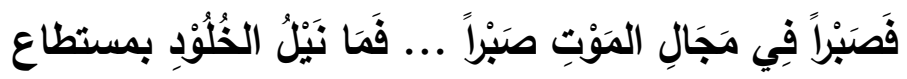

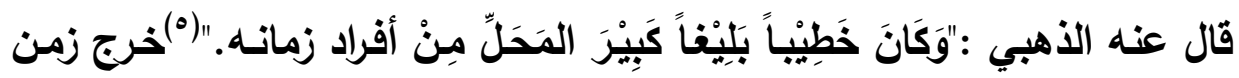
مصعب بن الزبيز لمسا ولهي العرلق نيابـة عن أخيه "عبد الله بن الزبير"،ويقي قطري عشرين سنة يقاتل ويسلم عليه بالخلافة، وكان الحجاج بن يوسف الثقفي يسير إليه جيشاً بعد جيش وهو يستظهر عليهم .

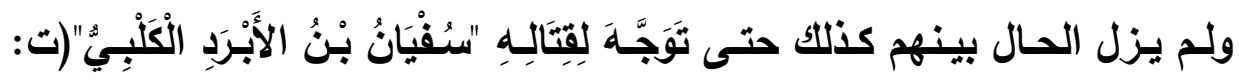

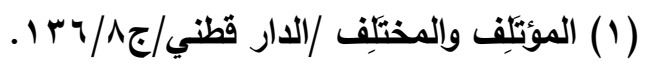

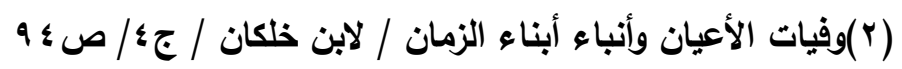

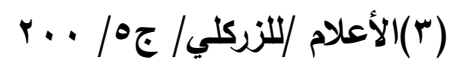

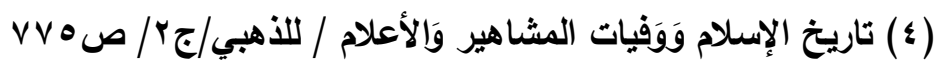

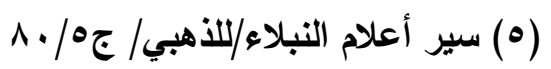

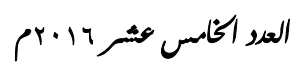

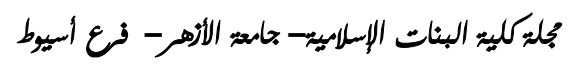

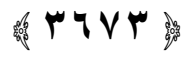




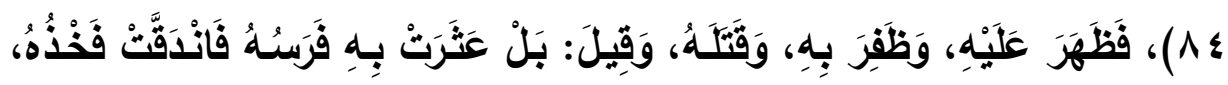

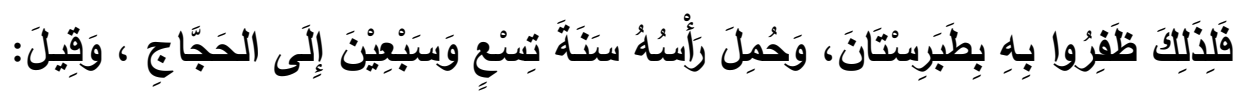

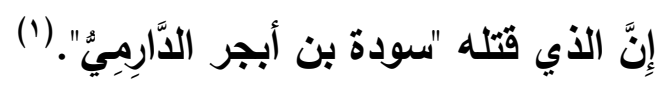

(1)وفيات الأعيان/ لابن خلكان/ \&/ ؟ 9، وانظر سير أعلام النبلاء / للذهب/ جه/.

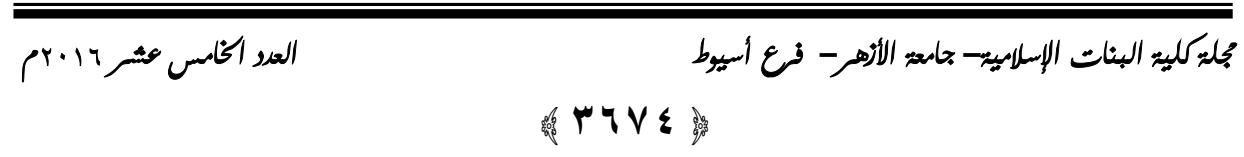




\section{البهمث الثماني \\ عقيدة التكثير عند الأزارقة. (1)}

لقد غلب على فكر الأزارقة نزعة التكفير، بل صار هذا ما يميزون به عن سـائر

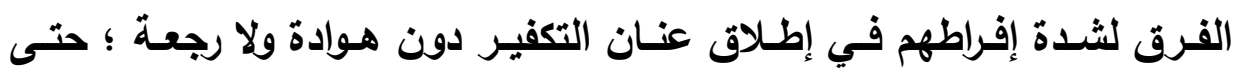
صارت العقيدة الأبرز والأظهر في فكرهم . ويظهر في عقيدة التكفير عند الأزارقة التشدد والتظلو في أعلى صوره ؛ فقد غاب عنهم الفهم السليم لآيات القرآن الكريم ، وأطبق عليهم الجهل بأحكام الشرع؛ فأفرطوا في التكفير، وإخراج الناس من الدين، وتطاولوا على أصحاب التبي . صلى الله عليه وسلم ـ ورموهم بما هم منه براء . المطلب الأول :تكفيرهم لأمير المؤمنين علي بن طالب ـ رضي الله عنه .

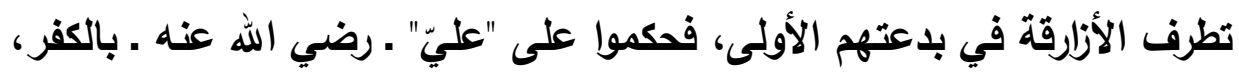

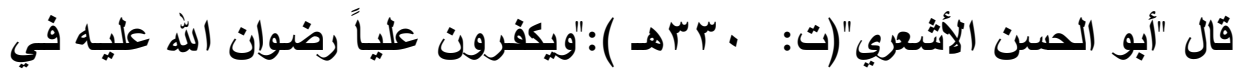

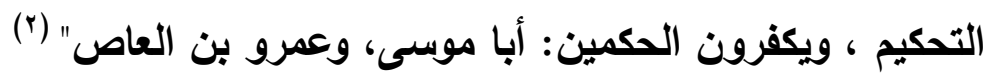

(1)تعددت ألفاظ العلماء في تعريف مصطلح الكفر فقد نقل الأزهري عن الليث في تعريفه أنه

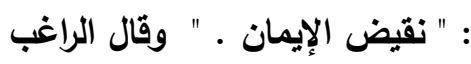
الأصفهاني: " والكافر على الإطلاق متعارف فيمن يجحد الريوبية، أو التبوة، أو الثريعة، أو

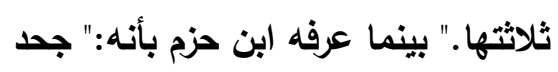

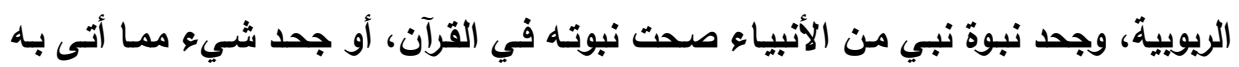
رسول

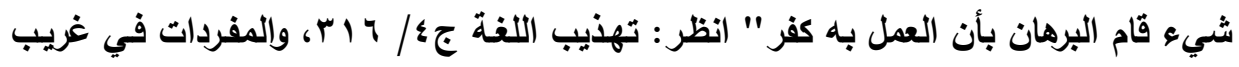

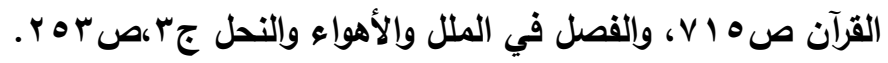

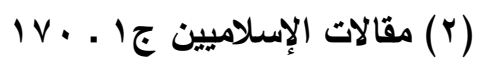

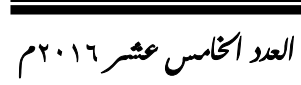
مجلةكليت البنات الإسلميت- جامع: الأهر- في أسيوط 
وحكى الشهرستاني ( ت: 1 ؛ هـ ) مقالة زعيمهم نافع بن الأزرق (ت:0 7هـ)

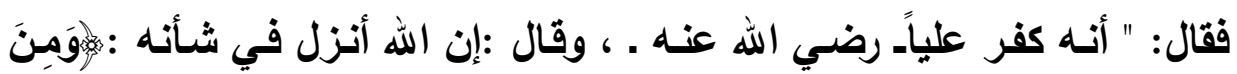

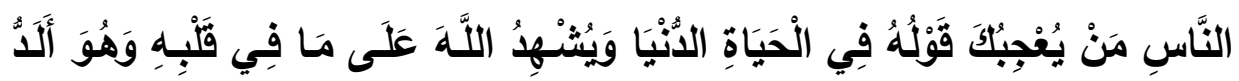

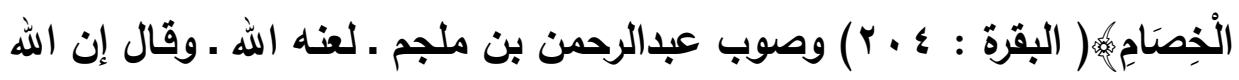

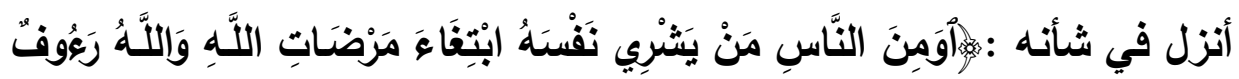

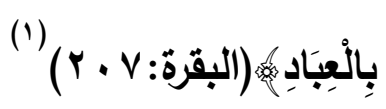

ويلغ من غلوهم ـ في افترائهم هذا ـ أن "عمران بن حطان" ( ت: ع ـهـ ) وهو مفتي الخوارج ، وزاهدها وشاعرها الأكبر أنشد في تصويبه "ابن ملجم" لعنه الله

يا ضرية من منيب ما أراد بها إلا

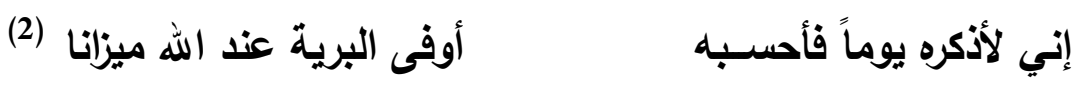

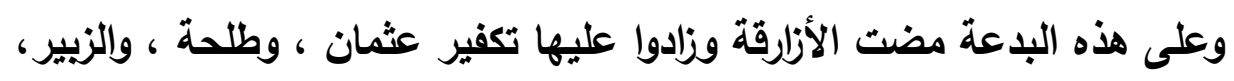
وعائشة ، وعبدالله بن عباس .

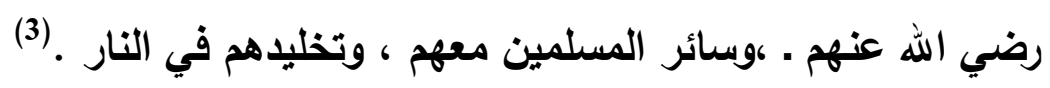
وتعد مسأكة التحكيم السبب الرئيس في غلو الأزارقة واعتقادهم تكفير الصحابة .

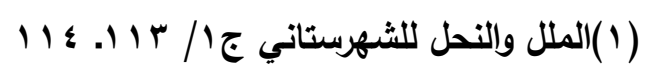
(r)قال ابن كثير: "وقدرد عليه بعض العلماء فيأبياته المتقدمة فيقتل علي ـ رضي الله عنه . بأبيات على قافيتها ووزنها : بنات بل ضرية منشقيما أراد بها ... إلا ليبلغ منذ يالعرش خسرانا

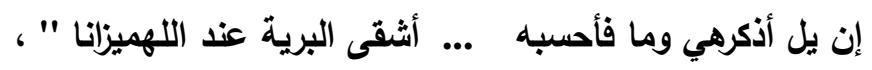

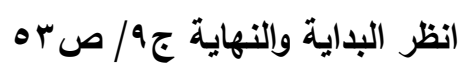

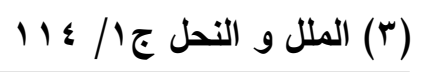

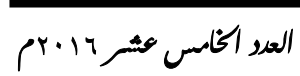
مجلةكليي: البنات الإسلميت- جامع: الأهر- فرع أسيوط

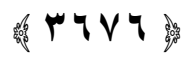


رضي الله عنهم ـ إذ أنـه من الثابت أنها أفرخت أول حزب سياسي تطرف في

آرائه وأحكامه ، وتبنى أفكاراً لم يعتادها المجتمع المسلم آنذاك (1) بيد أن الأزارقة جمعوا بين النقيضين ـ القبول والرفض ـ يوم صفين فهم من حملوا الإمام عليَ ـ رضي الله عنه ـ على قبول التحكيم طلباّ لحقن الدماء ، وهم أول مـن رفضـوه ، وحكمـوا بنـاءً عليـه بتكفير الإمـام علـيّ ومعاويـة رضـي الله عنهما، والحكمين ومن رضي بالتحكيم • ولهذا قال لهم الإمـام عليّ .رضـي الله عنـه ـ بعد انقلابهم عليه، ورفضـهم

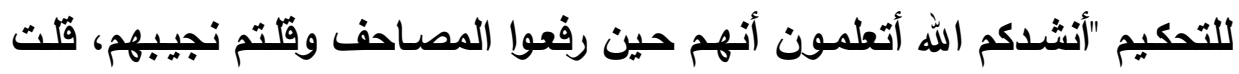
لكم: إنـي أعلم بـالقوم مـنكم، إنهـ ليسـوا بأصـحاب ديـن وذكر مـا كـان قالـه لهم" (r) وبساق "تافع بن الأزرق"(ت:0 7هـ) المبررات التي من أجلها أظهر البراءة من "عثمان" و"عليّ" ـ رضي الله عنهما ـ فقال : " وولي المسلمين من بعده ـ يعني مئي

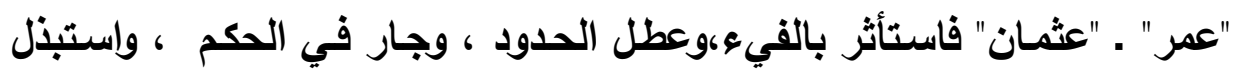

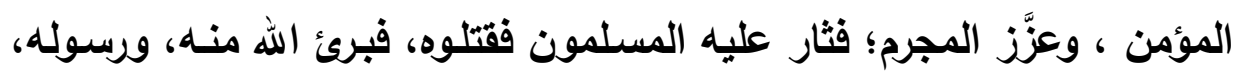
وصالح المؤمنين ، وولي أمر الناس من بعده "علي بن أبي طالب"،فلم ينشب

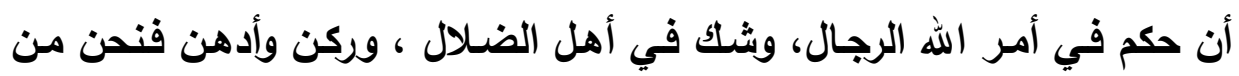

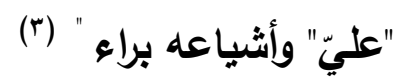

: تعقيب

(1) الخوارج الأصول التاريخية لمسألة تكفير المسلم. / مصطفى حلمي / ص \& 1.

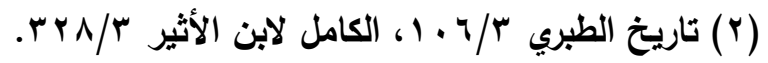

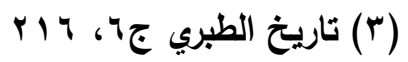

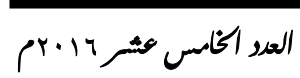

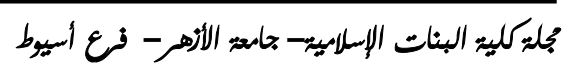
H TVV 
لا يخفى أن قدح الخوارج في الصحابة ـ رضي الله عنهم ـ والحكم عليهم بالكفر ضلال ويهتان، واضح بطلانه من عدة وجوه : الوجه الأول : تكذيب القرآن الكريم لما ادعاه الأزارقة من كفر الصحابة ـ رضي فهي الله عنهم . ؛ إذ أنه أثبت للصحابة من الفضائل التي ينتفي معها حكم الأزارقة

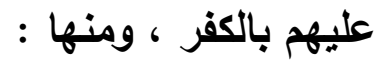
أولاً : : إخبار الله ـ تعالى ـ عن صحابة نبيه ـ صلى الله عليه وسلم ـ أنهم خير

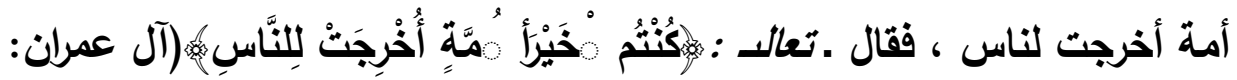
• 1 (1) ،وقال فيهم النبي ـ صلى الله عليه وسلم . "خير الناس

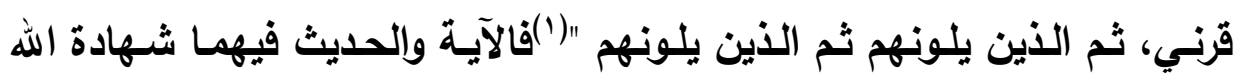
ورسوله للصحابة عموماً بأنهم خيز

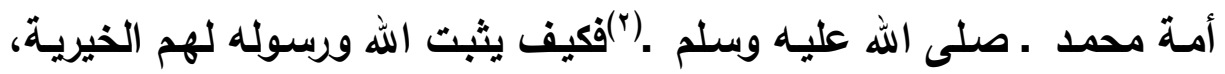
ويحكم الألزارقة بكفرهم ؟

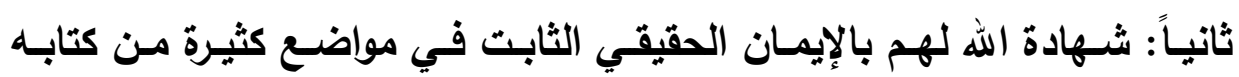

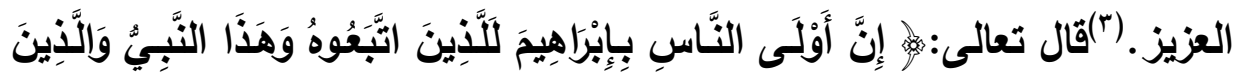

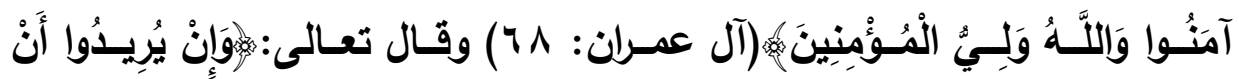

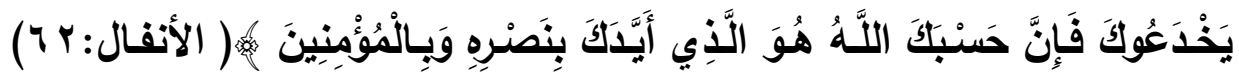

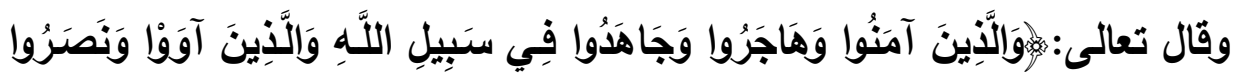

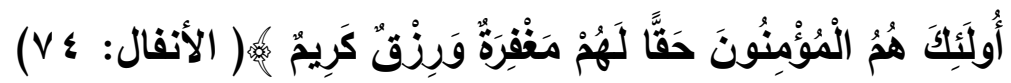

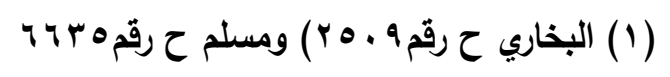

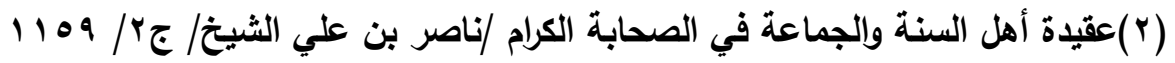

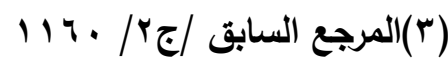

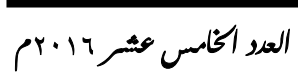
مجلةكليت البنات الإسلميت- جامع: الأهر- في أسيوط 
ثالثاً : إخبار الله ـ تعالى برضاه ـ سبحانه ـ عن الصحابة ورضـاهم عنه ،وأنـه

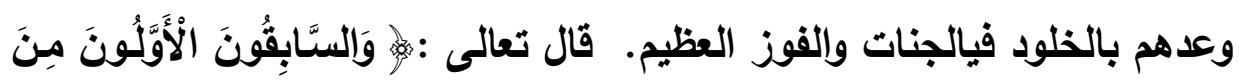

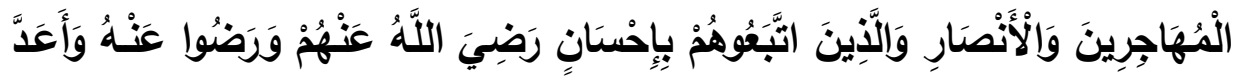

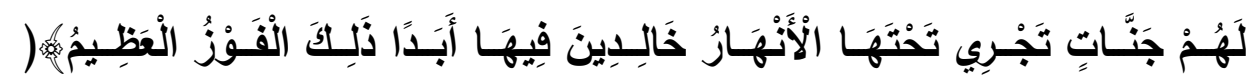
التوية: . (1)

الوجها الثاني : مـا ذكره عبد القاهر البغدادي من "أن الخازمية ('خالفوا أكثر

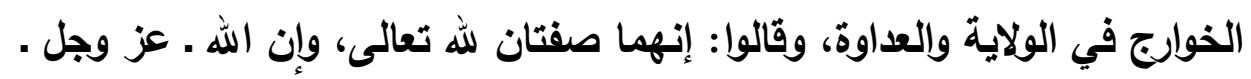

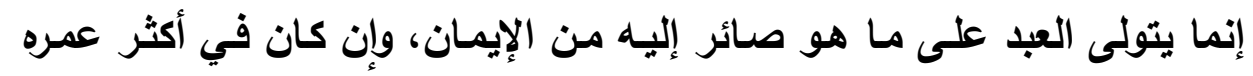

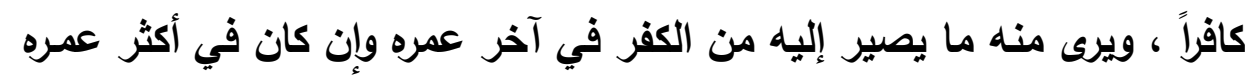

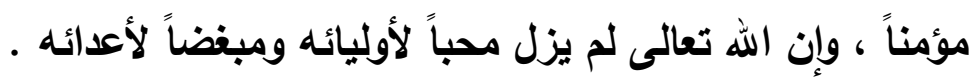

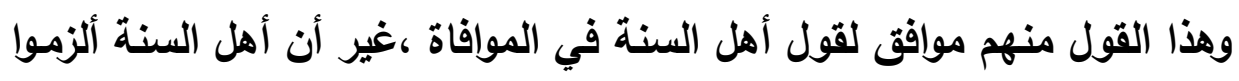

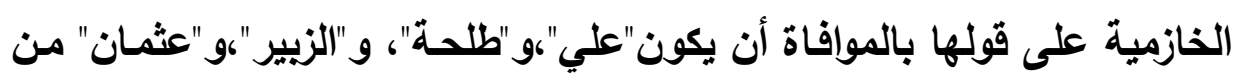

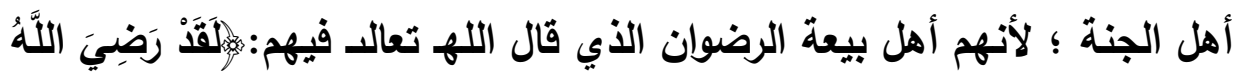

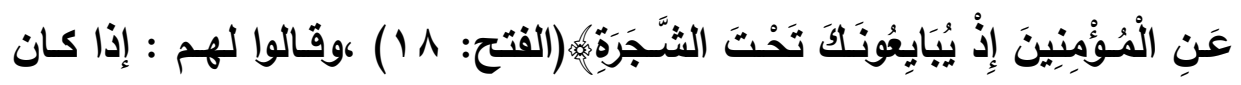

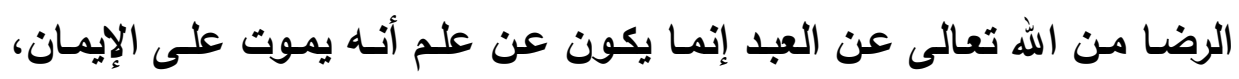

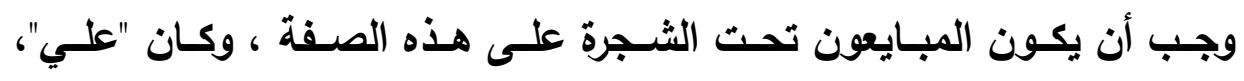

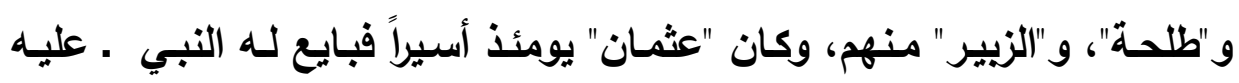

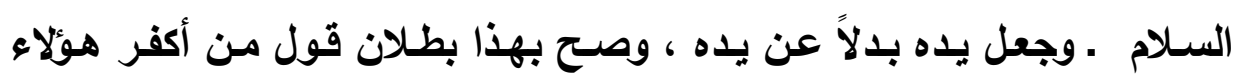

(1) هم أتباع حازم بن علي ، وقد قالوا في باب القدر ، والاستطاعة ، والمشيئة بقول أهل

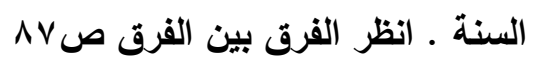

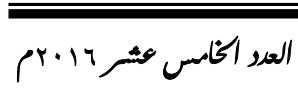

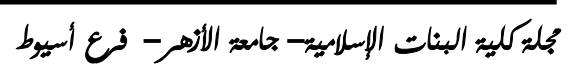
แ 
الأربعة "( (1)

الوجه الثالث: أن الكفر بعيد الوقوع من قوم أخبر الله تعالى أنـه بغَّض إليهم

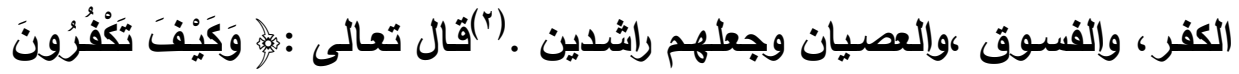

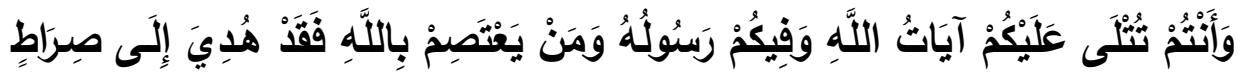

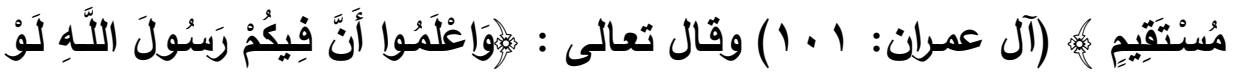

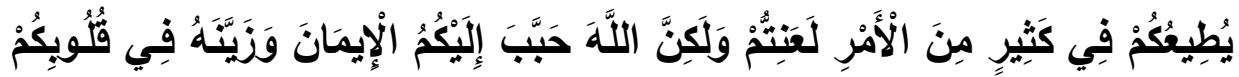

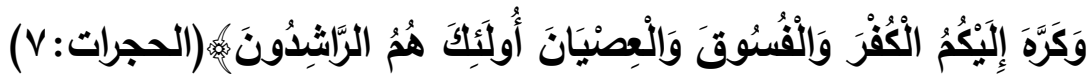
الوجه الرابع : أما قول "تافع بن الأزرق" إن الله أنزل في شـأن "علي" ـ رضي

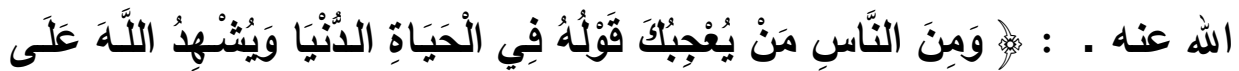

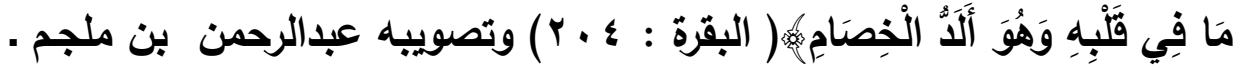

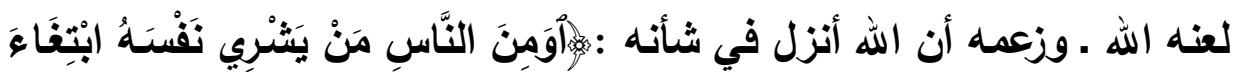

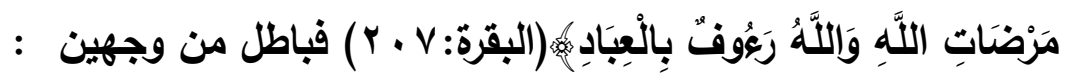

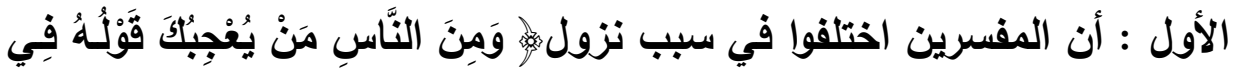

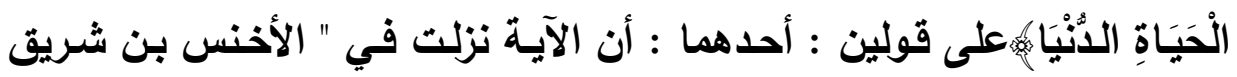

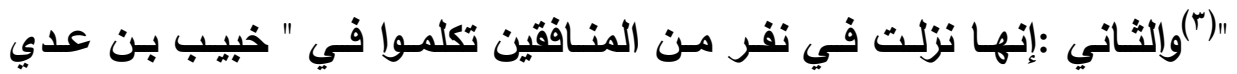

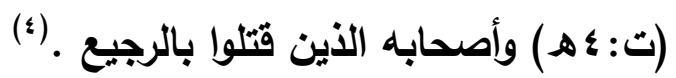

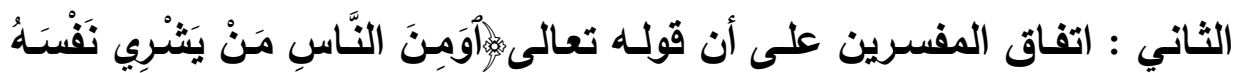

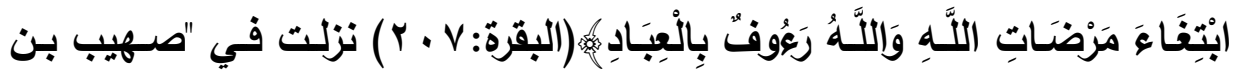

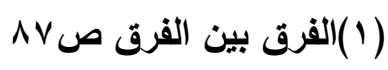

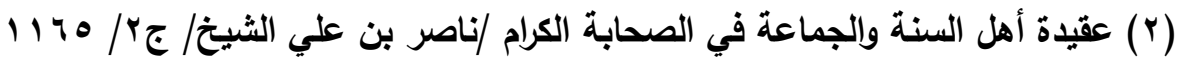

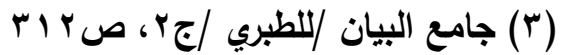

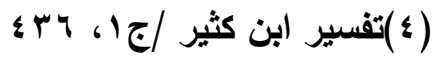

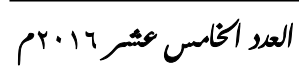

مجلةكليي: البنات الإسلميت- جامعي الأهر- في كع أسيوط 
سنان الرومي".(')ولم يقل أحد أنها نزلت في عبدالرحمن بن ملجم ـ لعنه الله . إلا الأزارقة ، وهذا دليل على ضلالهم وكذبهم على الله تعالى •

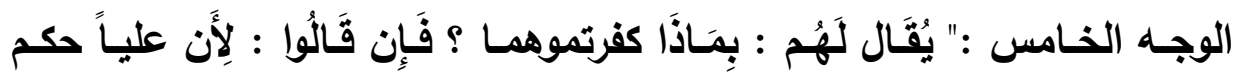

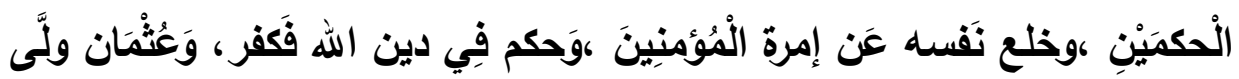

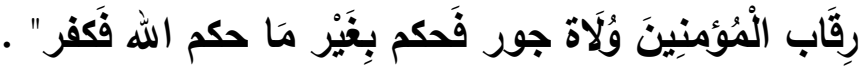

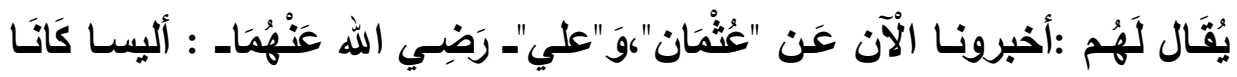

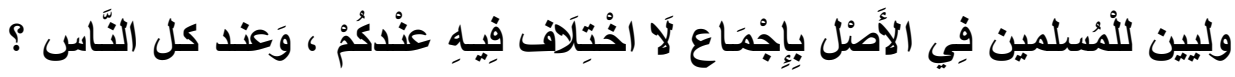

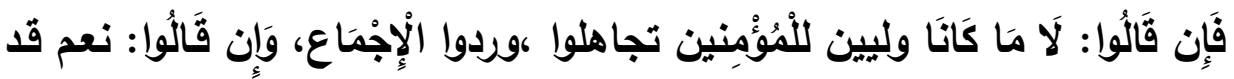

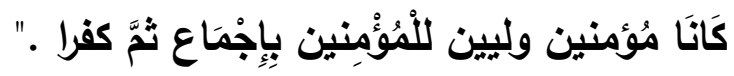

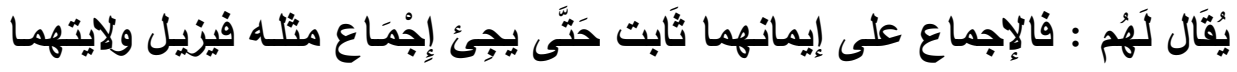

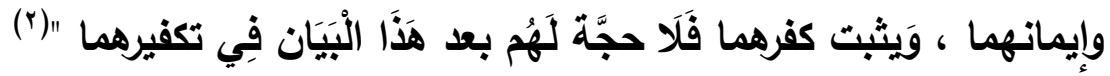
يتضح مما تقدم أن الأسـاس الذي بنوا عليه تكفيرهم لعلي - رضـى الله عنـه هو في الحقيقة أسـاس أوهى من بيت العنكبوت ؛ لأن قبولهـ التحكيم لا يعني

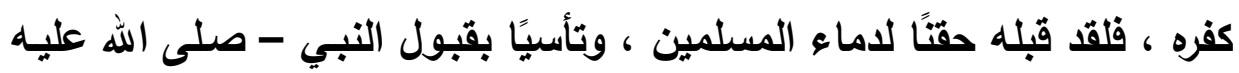

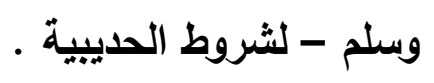

وكذلك ما أخذوه على عثمان - رضى الله عنه - والباقين ليس فيه كفرًا بواحًا ، فهم على الأقل لم يقولوا بـالكفر ولم يأتوه ، فضـلاً عن مكانتهم ، إن الأمر لا يعدوا إلا أن يكون اجتهادًا أو اختلافًا في الرأي . المطلب الثاني : تكفير القعدة .

$$
\begin{aligned}
& \text { (1) (أسباب النزول / للواحدي ص عـ }
\end{aligned}
$$

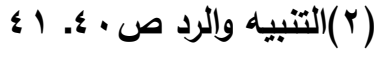

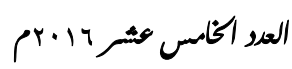

مجليكليي: البنات الإسلميت- جامعء الأهر- فرع أسيوط 
القَعَدُ جمع قاعد ، ونظيره حارس وخادم وخدم ، ويقال " قعدة" بالتاء ، ونظيره

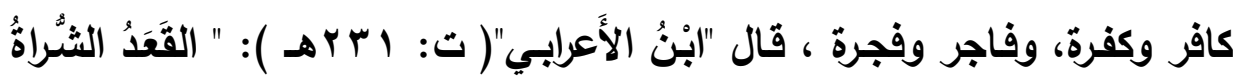

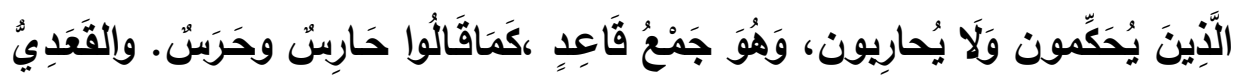

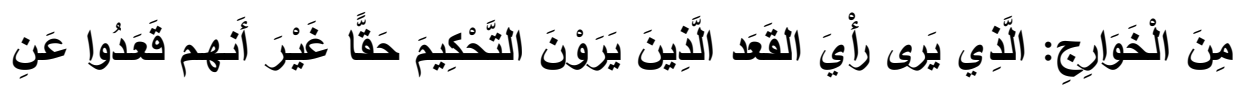

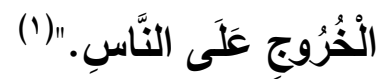

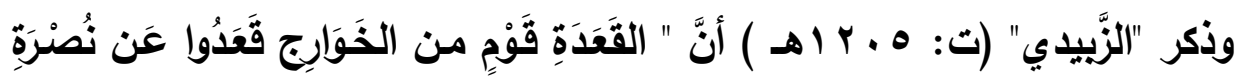

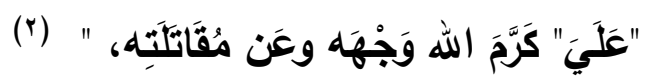

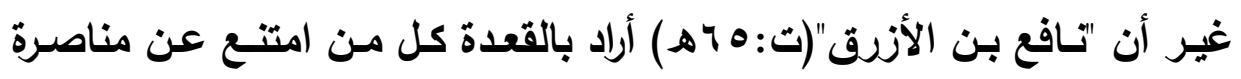

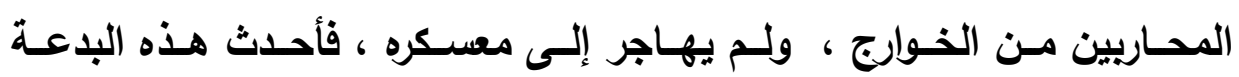

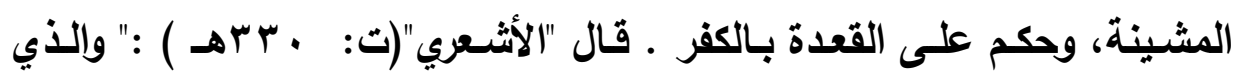
أحدثه البراءة من القعدة ، والمحنة لمن قصد عسكره ، وإكفار من لم يهاجر إليه اليه (ए) ".

ولم يفرق الأزارقة في حكمهم على القعدة بين المخالفين لهم في الرأي، ويبن

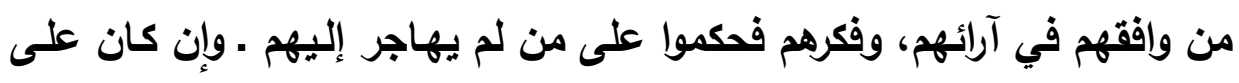

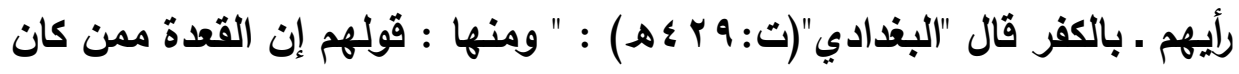

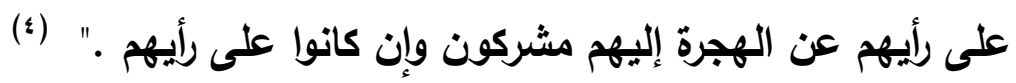

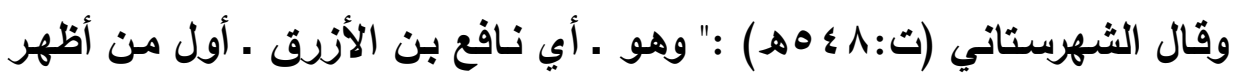

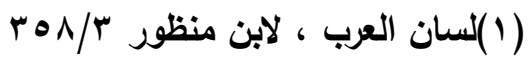

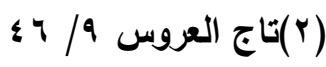

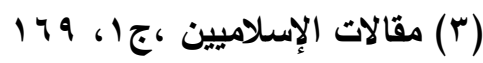

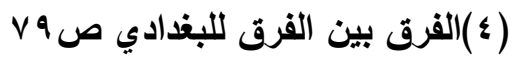

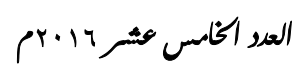

مجلةكليت البنات الإسلاميت- جامعة الأهر- فع أسيوط 


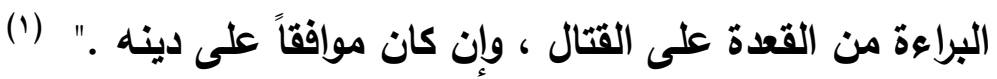

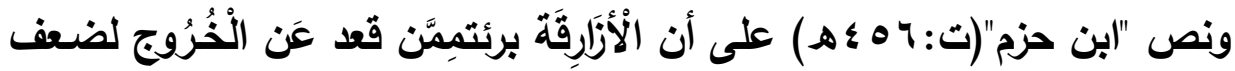
أَو غَيره ، وكفروا من خالف هذا القول بعد موت أول من قال بـه منهم ، ولم

يكفروا من خالفه فيه في حياته (r)

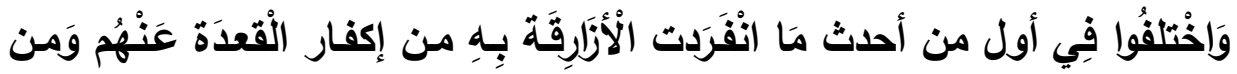
امتحان من قصد عَنْكَرهمْ :

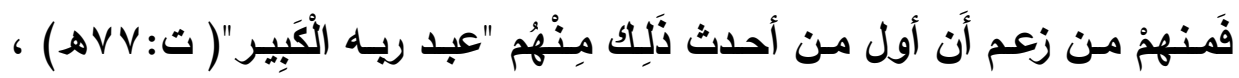

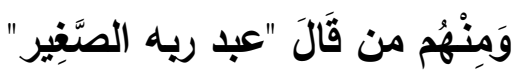

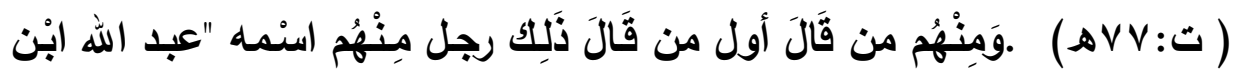

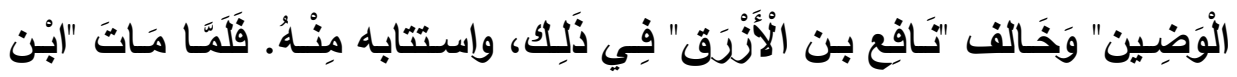

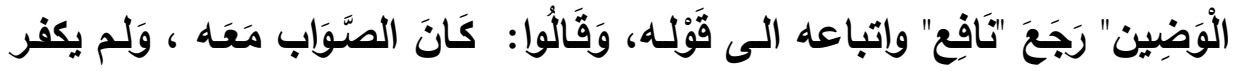

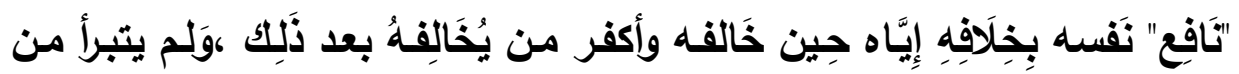

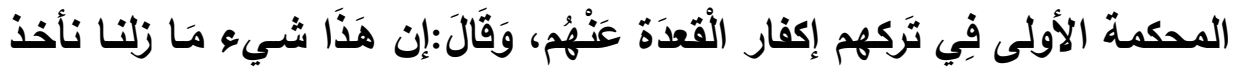

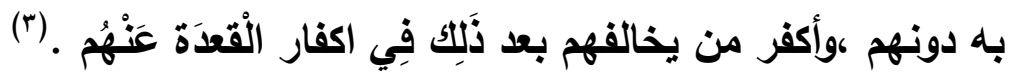
وأنكر نافع بن الأزرق على المحكمة في البصرة قعودهم بين أظهر الكفار فكتب

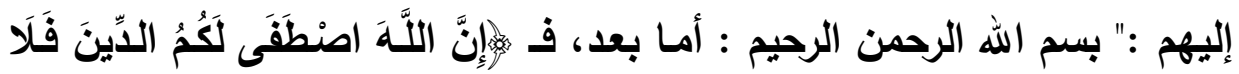

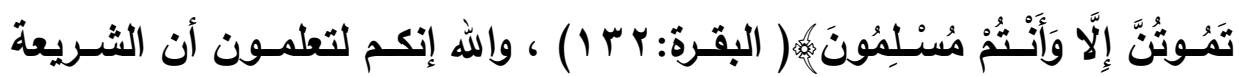
واحدة، والدين واحد، فقيم المقام بين أظهرالكفار؟ ترون الظلم ليلاً ونهاراً، وقد

(1) الملل والنحل للشهرستاني 110/1 المهان

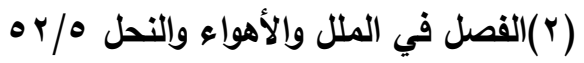

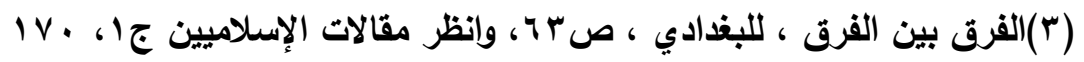

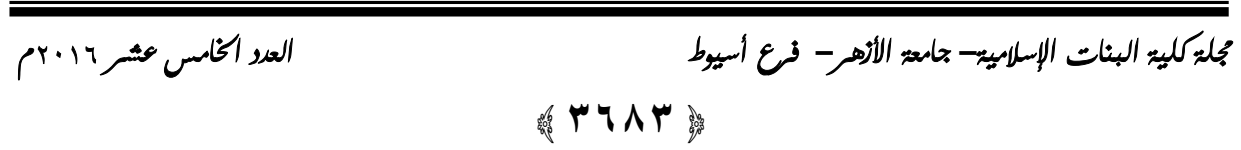




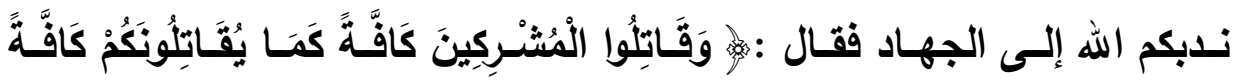

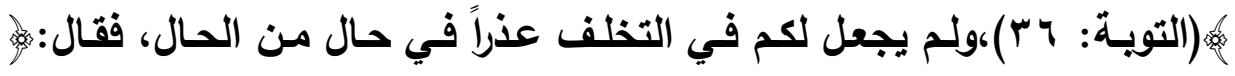

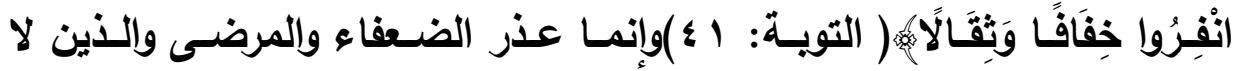
يجدون ما ينفقون، ومن كانت إقامته لعلة، ثُ فضل عليهم مع ذلك المجاهدين،

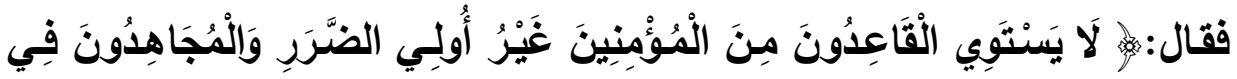

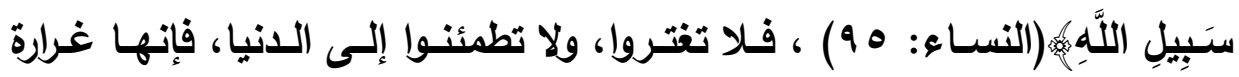
مكارة، لذتها نافذة، ونعمتها بائدة، حفت بالثـهوات اغتراراً، وأظهرت حبرة. وأضمرت عبرة، فليس آكل منها أكلة تسره، ولا شارب شرية تؤنفه؛ إلا دنا بها

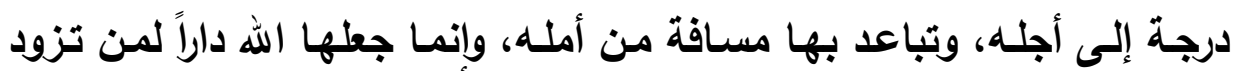

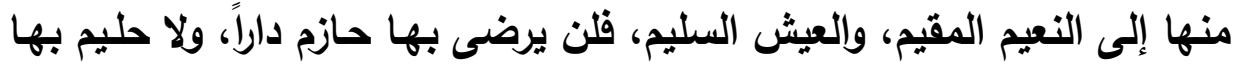

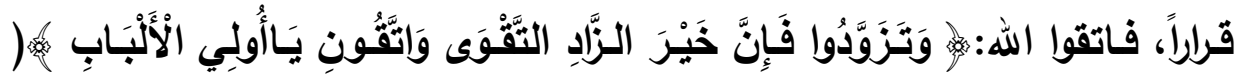

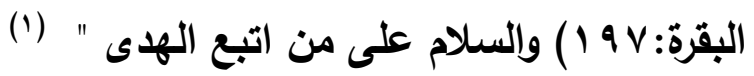

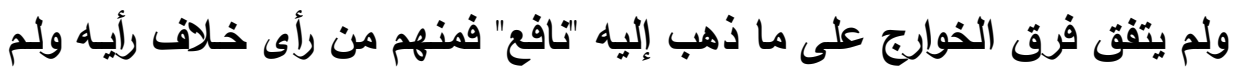

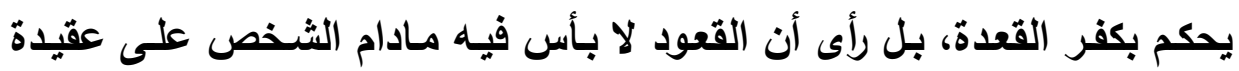

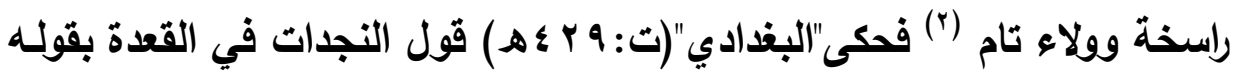

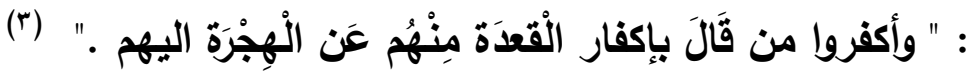

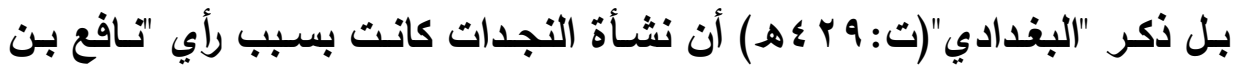

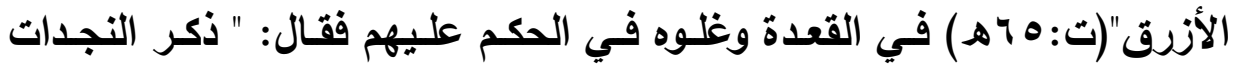

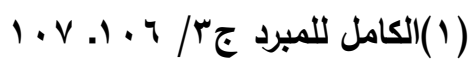

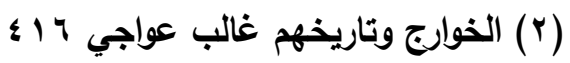

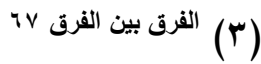

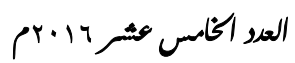$$
\text { مجليَكليت البنات الإسلاميت- جامع: الأهر- فع أسيوط }
$$ 


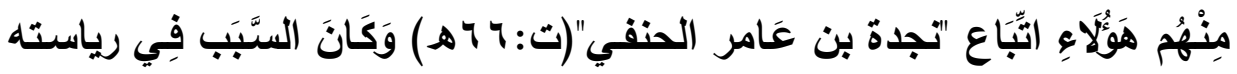

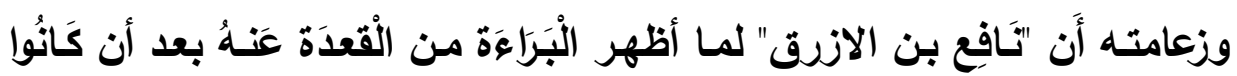

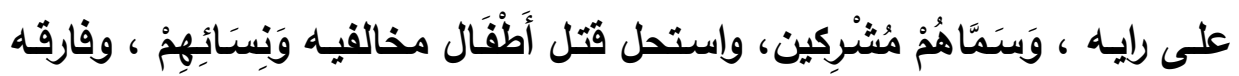

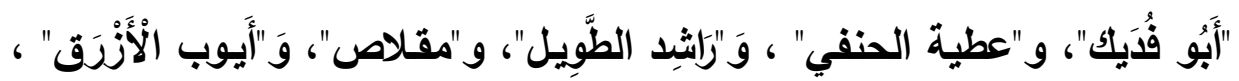

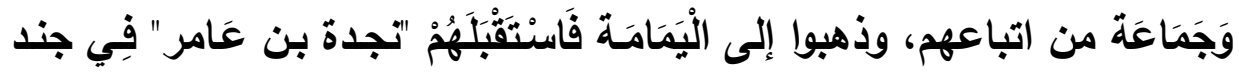

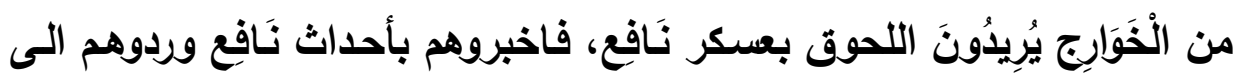

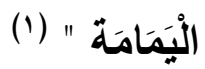

وجرت مكاتبات بين "تجدة" و"تافع" حول حكم القعدة إلا أن "تافع بن الأزرق"

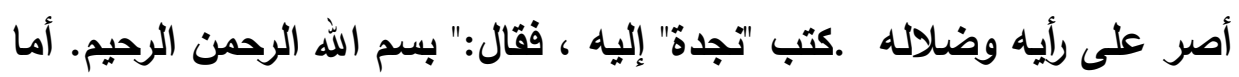

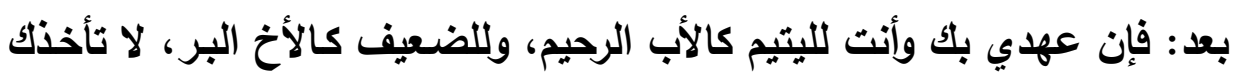

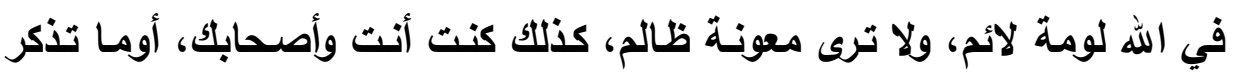

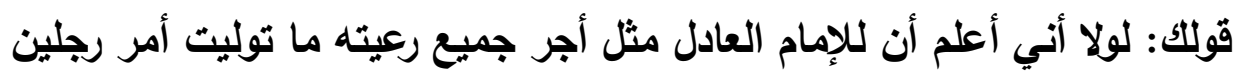

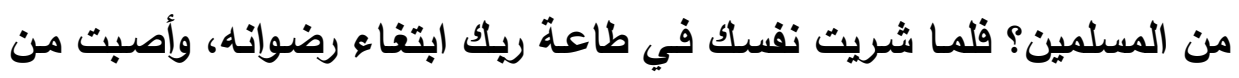
الحق فصه، وركبت مره، تجرد للك الثيطان، ولم يكن أحد أثقل عليه وطأة منك فئك

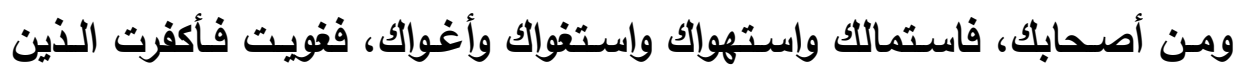

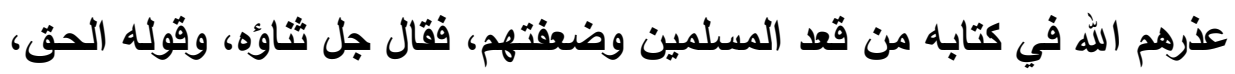

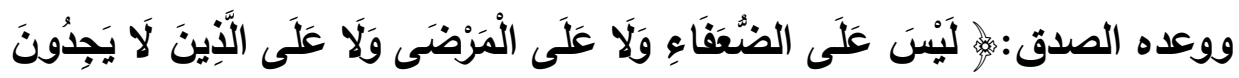

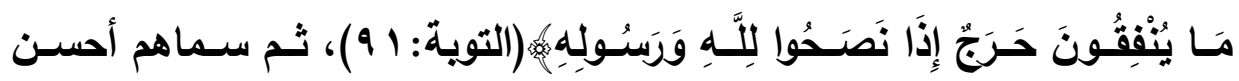

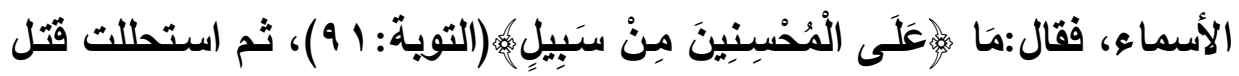

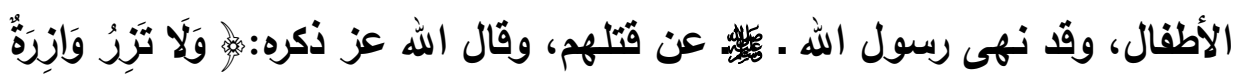

الفرق بين الفرق ، للبغدادي ، VV

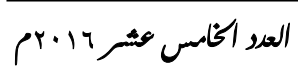

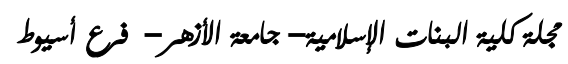
(4 


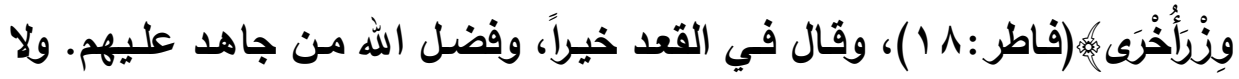

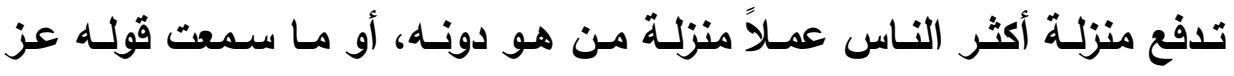

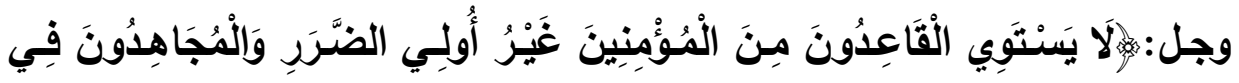

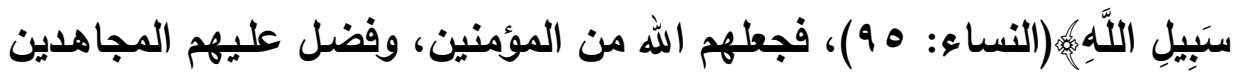
بأعمالهم، ورأيت ألا تؤدي الأمانة إلى من خالقك، والله يأمر أن تؤدى الأمانـات

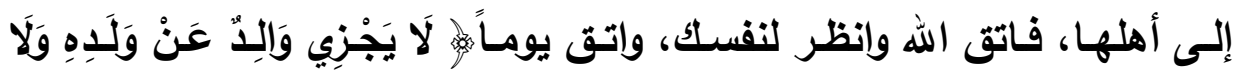

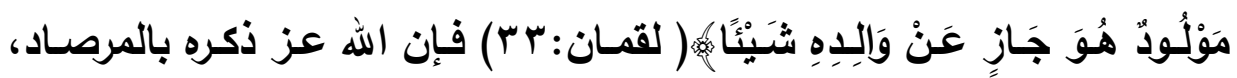

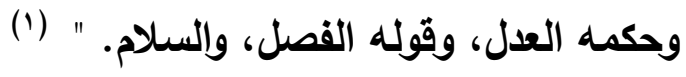

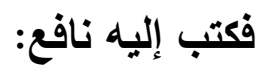
"بسم الله الرحمن الرحيم. أما بعد: فقد أتاني كتابك تعظني فيه وتذكرني، وتتصح لي وتزجرني، وتصف ما كنت عليه من الحق، وما كنت أوثره من الصواب، وأنـا أسأل الله جل وعز أن يجعلي من الذين يستمعون القولفيتبعون أحسنه، وعبت علَّ ما دنت به من إكفار القعد وقتل الأطفال واستحلال الأمانـة، فسأفسر للك لـ لم ذلك إن شاء الله : أما هؤلاء القعد فليسوا كمن ذكرتم من كان بعهد رسول الله

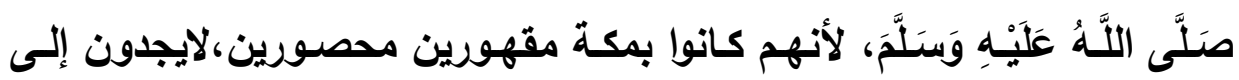
الهرب سبيلاً، ولا إلى الاتصال بالمسلمين طريقاً، وهؤلاء قد فقهوا في الدين،و قرأوا القرآن، والطريق لهم نهج واضـح، وقد عرفتما قال الله عز جل فيمن كان

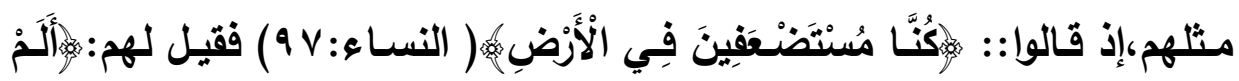

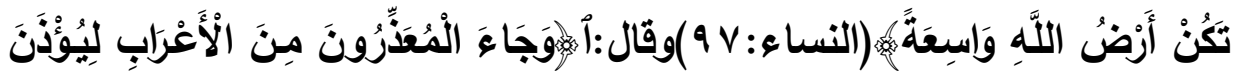

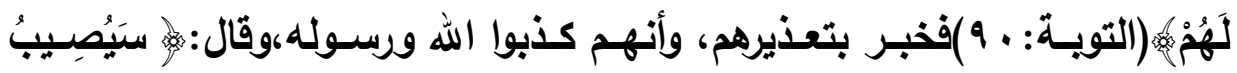

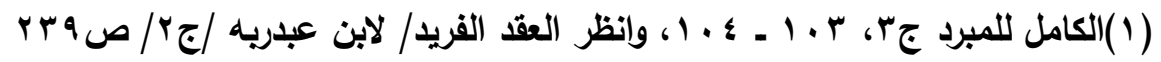

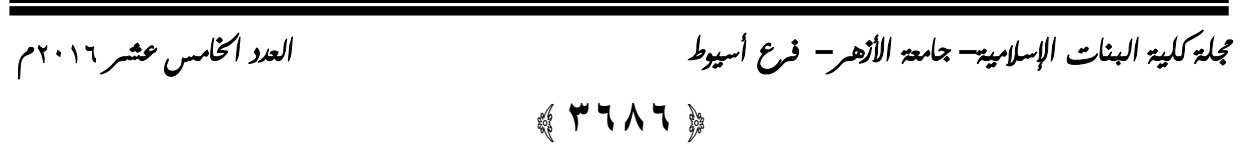




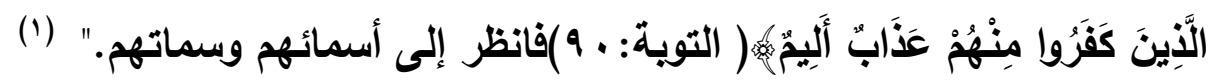
ويتضح من خلال حديث الأزارقة عن باعتهم هذه ما يلي :

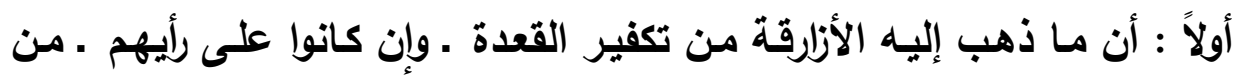

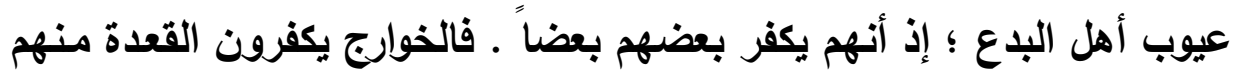

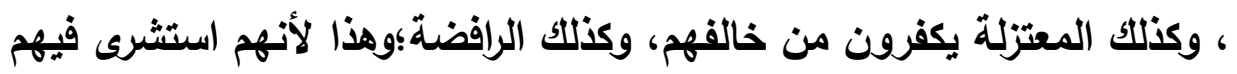

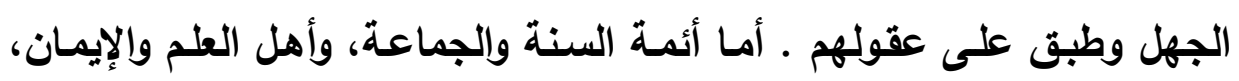

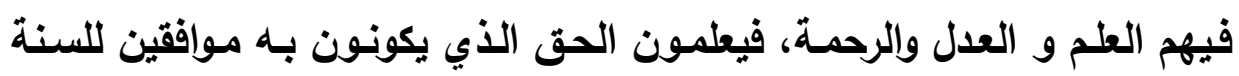

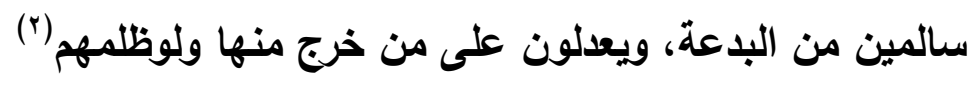

ثانياً :أن الخوارج هم أول من كفر المسلمين، يكفرون بالذنوب، ويكفرون من

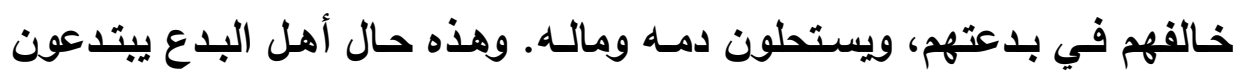

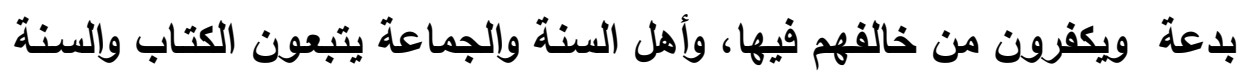

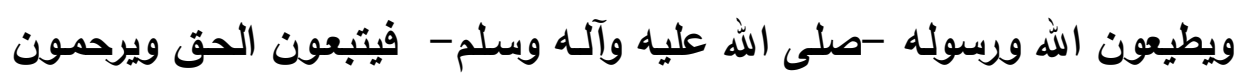

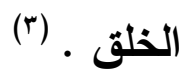

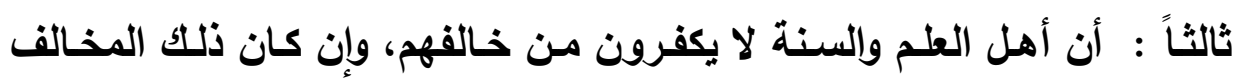

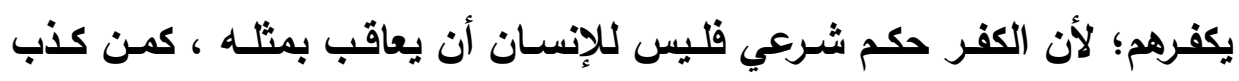

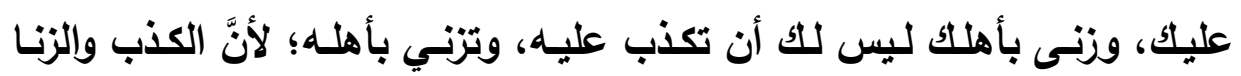

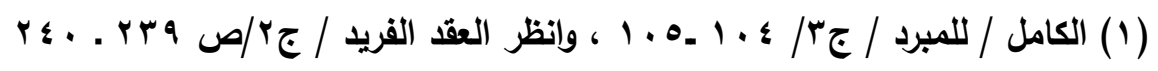

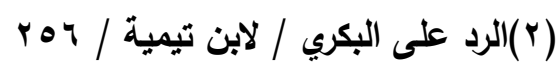

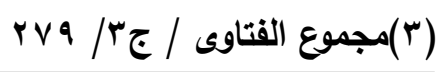

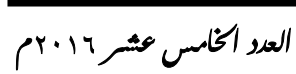

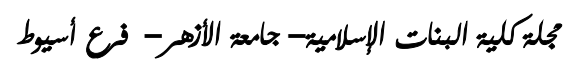
แัง 


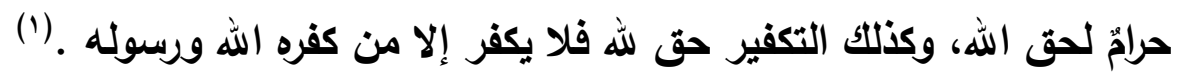
المطلب الثالث : تكفير مرتكب الكبيرة. اختلف العلماء في تعريف الكبيرة على أقوال كثيرة جداً ولعل أرجحها ما ذكره

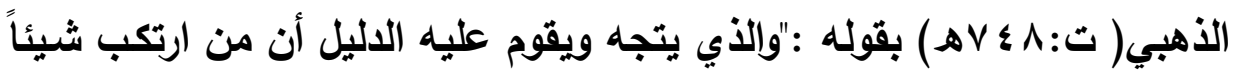
من هذه العظائم ممـا فيه حد في الدنيا كالقتل، والزنا، والسرقة، أو جاء فيهـ وعيد في الآخرة من عذاب، أو غضب، أو تهديد، أو لعن فاعله على لسنان لسان نبينا

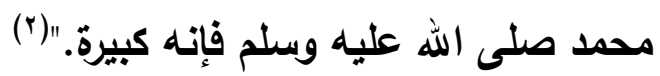

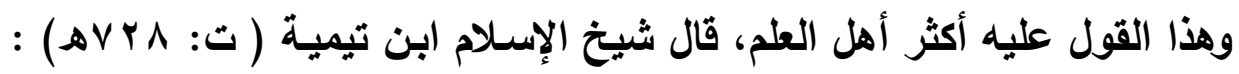

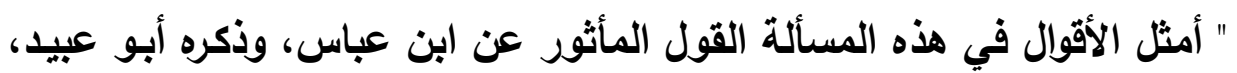
وأحمد بن حنبل، وغيرهما وهو: أن الصغيرة مـا دون الحدين: حد الدنيا وحد

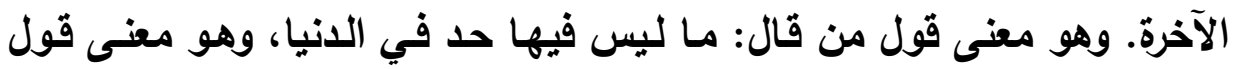

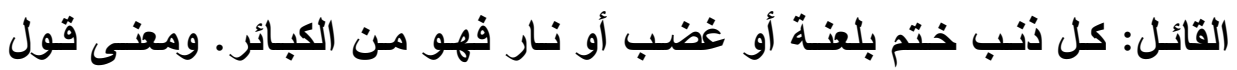
القائل: وليس فيها حد في الدنيا ولا وعيد في الآخرة أي " وعيد خاص عل " كالوعيد

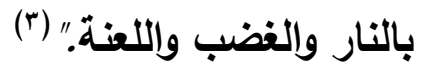

وقد تنازعت الفرق والمذاهب في اسم مرتكب الكبيرة وحكمه إلى طرفين ووسط : الطرف الأول : الغلو ويمثله: اــ الخوارج فقد قالوا:"مـا النـاس إلا مؤمن أو كافر؛ والمـؤمن من فعل جميع الواجبات وترك جميع المحرمات؛ فمن لم يكن كنلك فهو كافر؛ مخلد في النار.

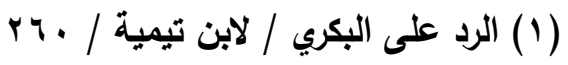

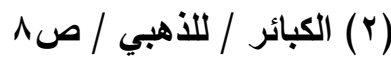

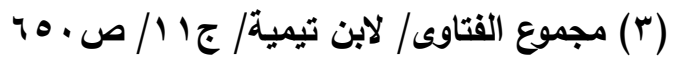

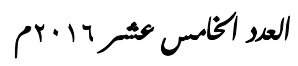

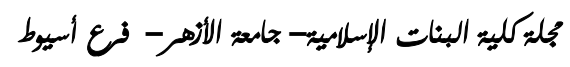

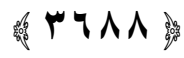




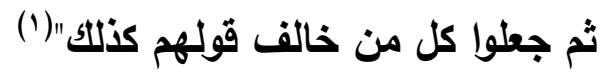
זـ المعتزلة: فقد قالوا: " أهل الكبائر مخلدون في فئل النار كما قالت الخوارج ولا

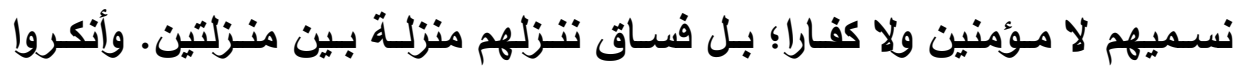

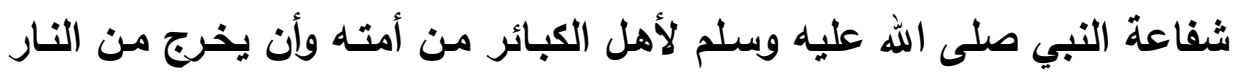

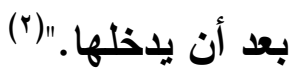

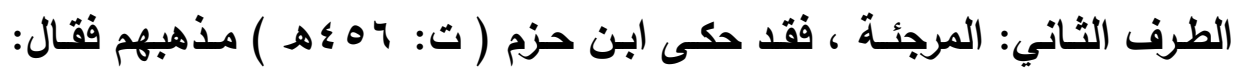

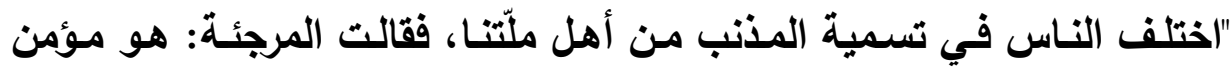

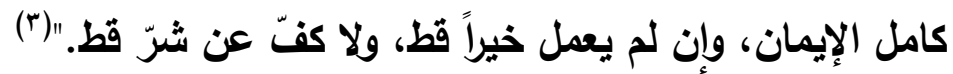
وقال ابن تيمية ـ رحمه الله ـ : " فقالت المرجئة: جهميتهم وغير جهميتهم: هو الهون

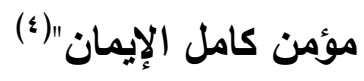
وقال ـ رحمه الله تعالى . : " المرجئة الواقفة " الذين يقولون: لاندان الدري هل يلخل

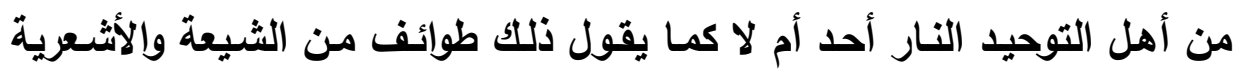

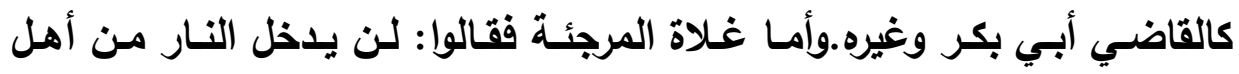

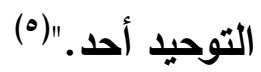
أما الوسط فأهل السنة والجماعة، إذ يعتقدون أن مرتكب الكبيرة مسلم فاست لا

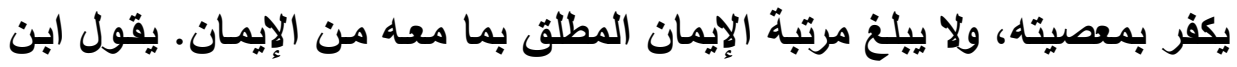

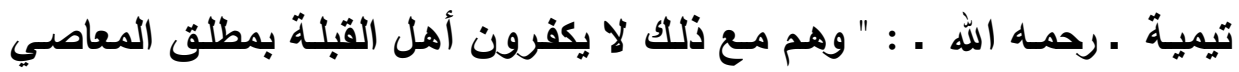

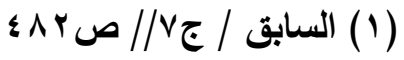

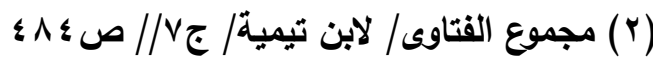

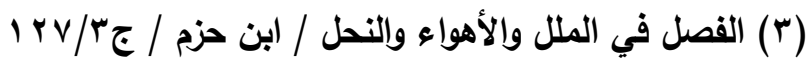

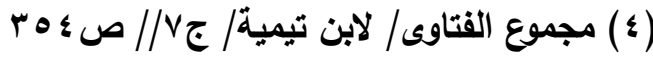

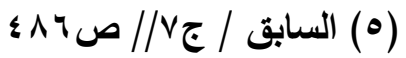

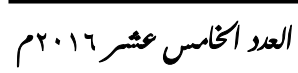

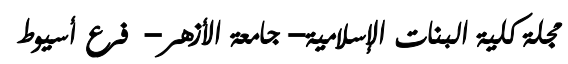


والكبائر كما يفعله الخوارج؛ بل الأخوة الإيمانيـة ثابتة مـع المعاصي.....، ولا يسلبون الفاسق الملي اسم

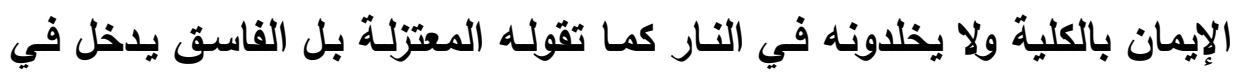

(اسم الإيمان."( الإنمان باله ولان ويعتقد أهل العتّة أن مرتكب الكبيرة في الآخرة تحت مشيئة الله تعالى، إن شـاء

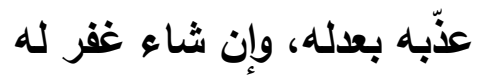

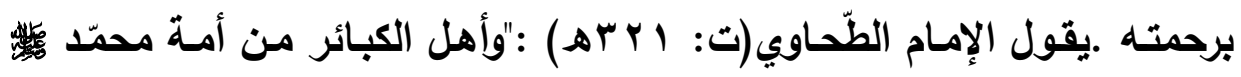

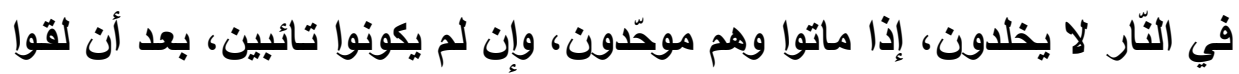

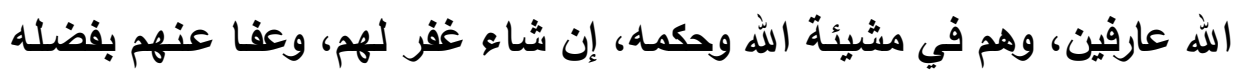

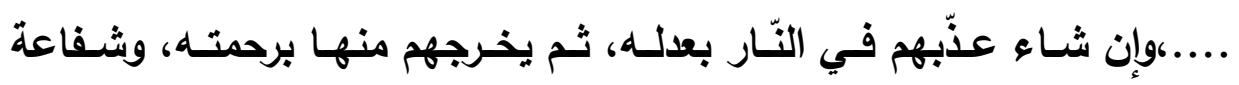

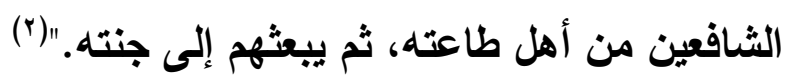

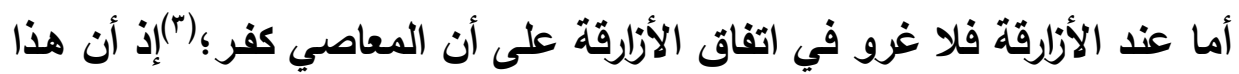

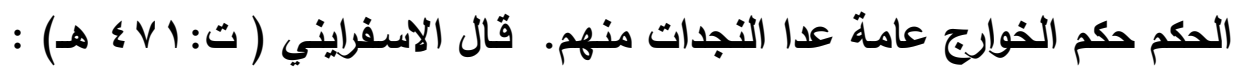

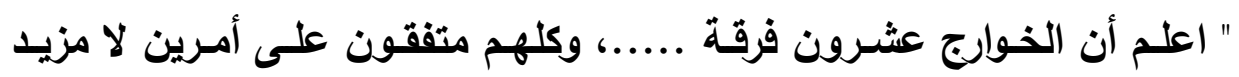
عليهما في الكفر والبدعة : أحدهما: إنهم يزعمون أن "علياً، و"عثمان"، وأصحاب الجمل ، والحكمين، وكل من رضي بالحكمين كفروا كلهم . الثاني : إنهم يزعمون أن كل من أذنب ذنباً من أمة محمد ـ صلى الله عليه

$$
\begin{aligned}
& \text { (1) مجموع الفتاوى/ لابن تيمية/ جr// ص } 1010
\end{aligned}
$$

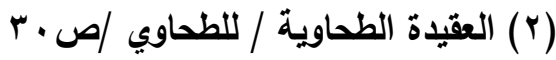

$$
\begin{aligned}
& \text { \& }
\end{aligned}
$$

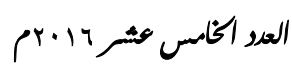

مجلةكليي: البنات الإسلميت- جامع: الأهر- في كع أسيوط 
وسلم - فهو كافر ، ويكون في النار مخلداً إلا النجدات منهم فإنهم قالوا : إن إن إنها

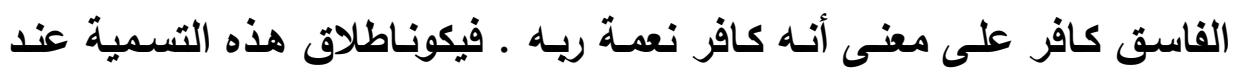

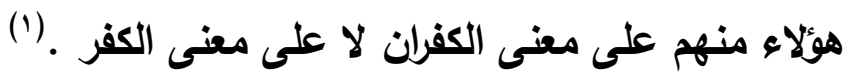

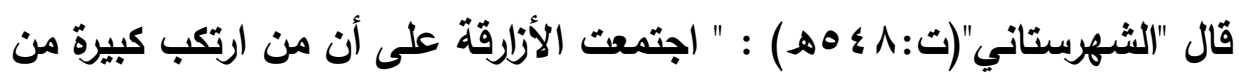

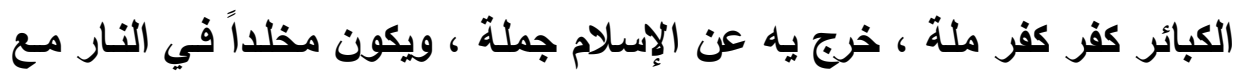

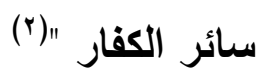

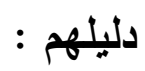

استدل الألارقة على ما ذهبوا إليه في الحكم على مرتكب الكبيرة بكفر إبليس -

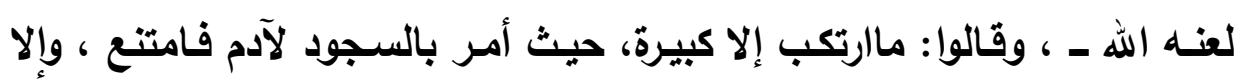

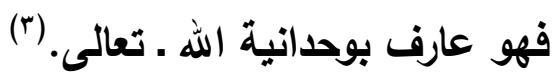

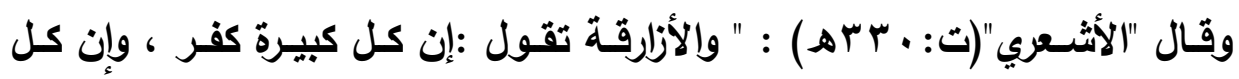

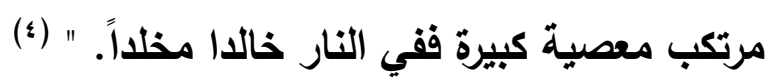

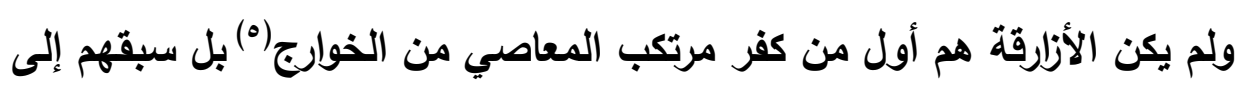
ذلك الحكم "المحكمة الأولى ".

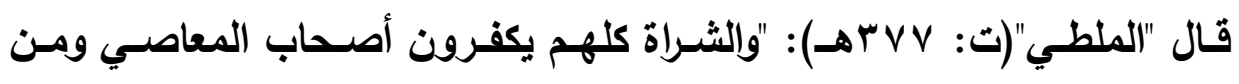

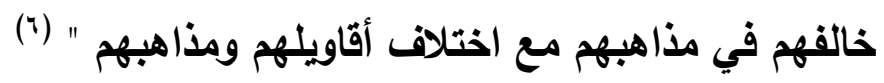

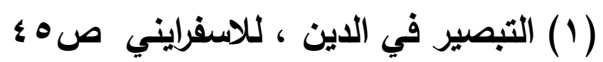

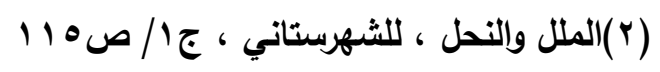

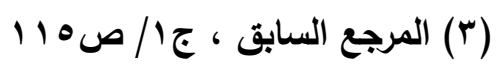

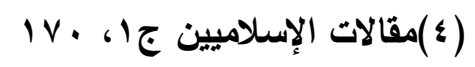

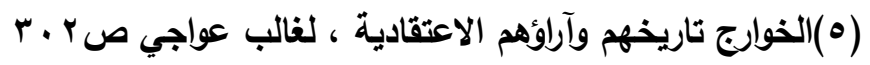

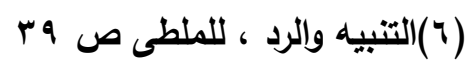

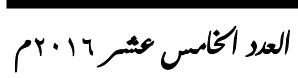

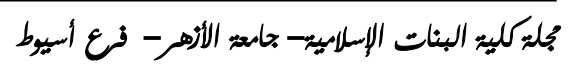


ويؤكد ذلك "البغدادي" (ت: 9 ؟ ؛ هـ) بقوله :" فهذه قصة المحكمة الأولى ، وكان

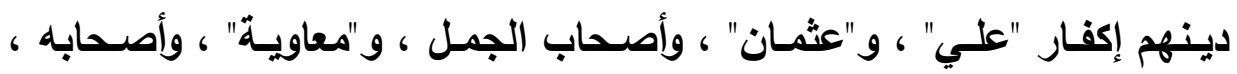

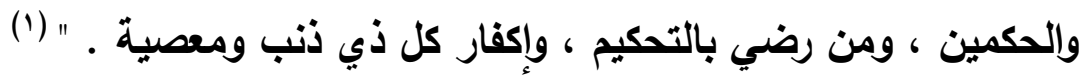

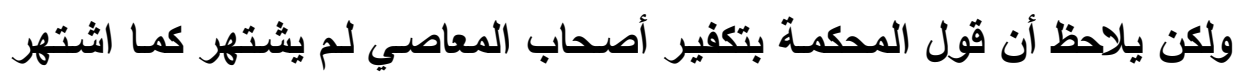

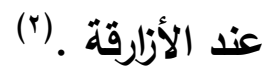

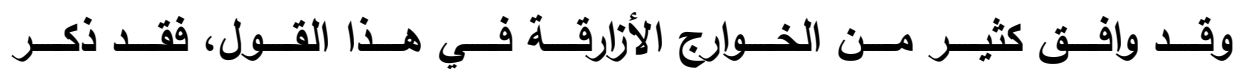

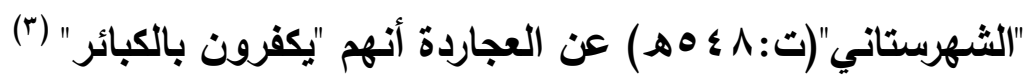

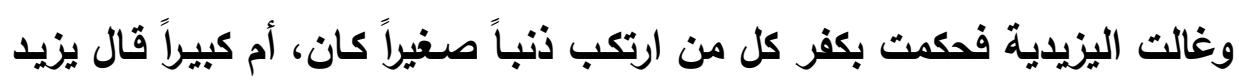

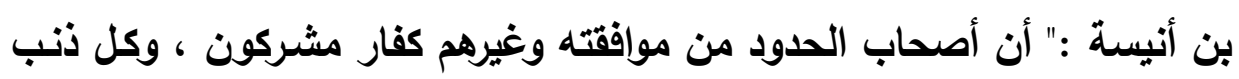

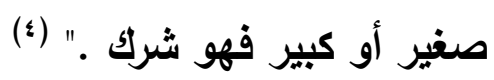
وهـا الموقف المتثـدـد مـن الأزارقـة تجـاه أصـاب المعاصـي ، هـو نتيجـة لاعتبارات عدة :

الأول : هو موقفهم المتثدد في الاين ، فقد كانوا أهل عبادة ، وتمسكوا بظواهر النصوص ، ولم يقبلوا التهاون أو التفريط في حد من حدود الله ـ تعالى .

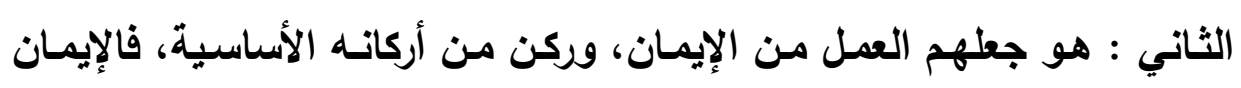

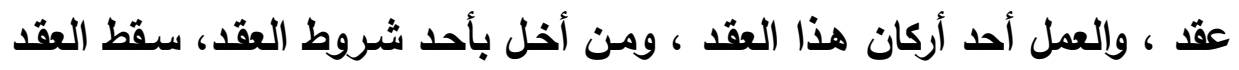

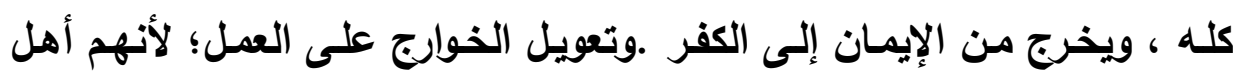

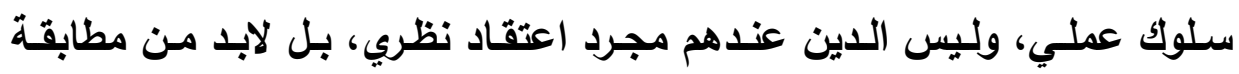

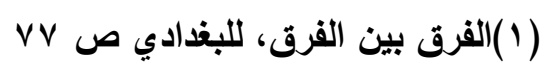

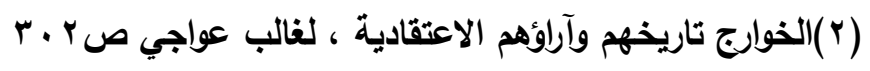

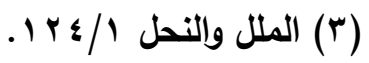

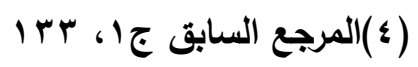

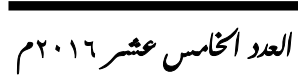

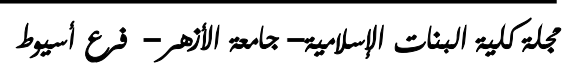




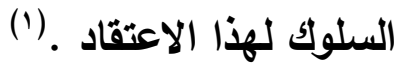

ولهذا رتب الأزارقة على قولهم بتكفير مرتكب الكبيرة أحكاماً منها : ا. استحلال دماء وأموال المخالفين؛ لأنهم يعتبرون ديارهم دار كفر يقول "تـافع هون بن الأزرق"(ت:07هـ): " الدار دار كفر . يقصد دار المخالفين - إلا من أظهر إيمانه، ولا يحل أكل ذبائحهم، ولا تناكحهم، ولا توارثهم، ومتى ما جاء منهم جاء فعلينا أن نمتحنه، وهم ككفار العرب لانقبل منهم إلا الإسلام أو وله (السيف" جاء مناء) rـ أوجبـوا الهجرة والفـرار بالدين إلى أمساكن نفوذهم، حتى يتمكنـوا مـن إقامـة مجتمعهم المنشود قال نافع بن الأزرق: "والله إنكم لتعلمـون أن الشـريعة واحدة، واللدين واحد، فقيم المقام بين أظهر

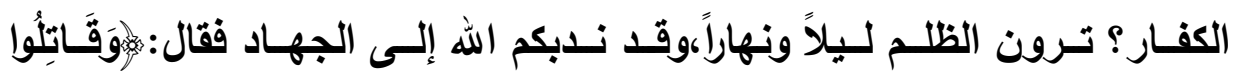

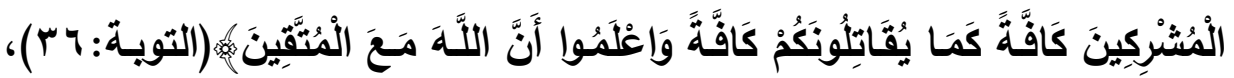

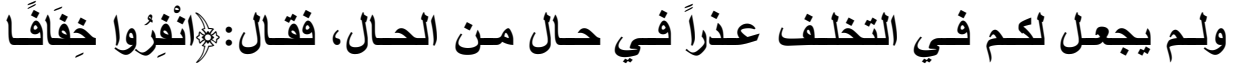

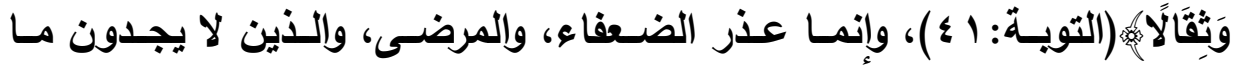
ينفقون، ومن كانت إقامته لعلة، ثم فضل عليهم مع ذلك المجاهدين،

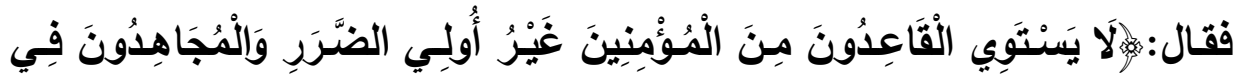
سَبِيلِ اللَّهِ

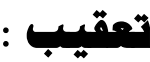

(1) الفرق الكلامية الإسلامية مدخل ودراسة ، علي عبدالفتاح مغربي ، ص1V7)

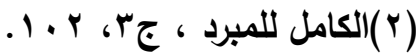

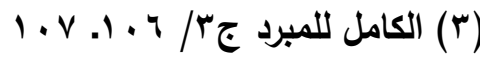

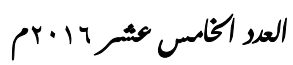
مجليكليي: البنات الإسلميت- جامع: الأهر- فئ أسيوط 
تعقب الملطي (ت : rVV ) تكفير الأزارقة لمرتكب الكبيرة بالمناقشة والتقنيد ، لبيان ضلالهم ويطلان ما ذهبوا إليه ، وذلك بما يلي :

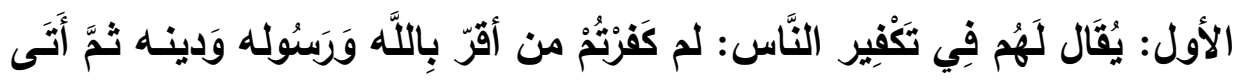

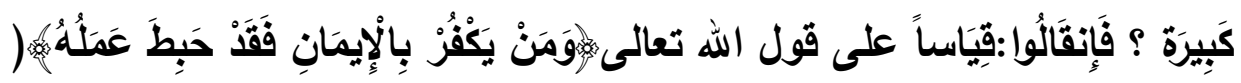

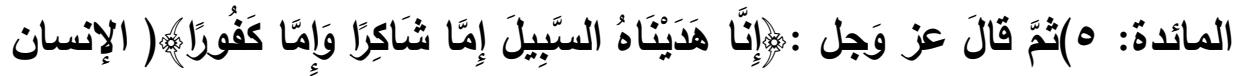

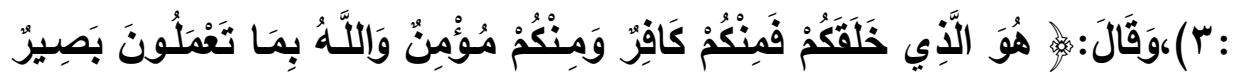

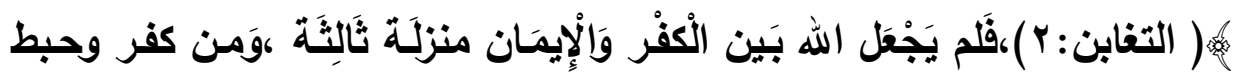

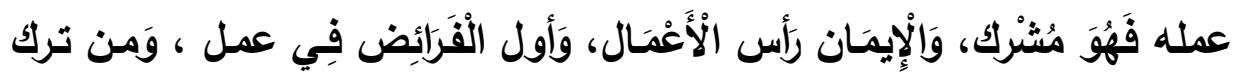

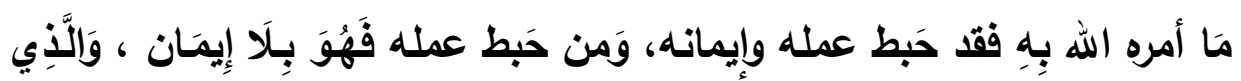

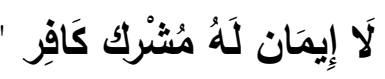

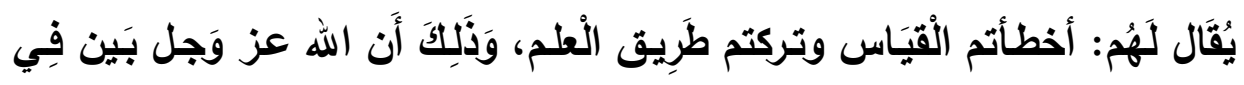

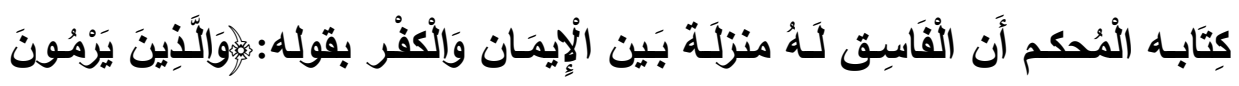

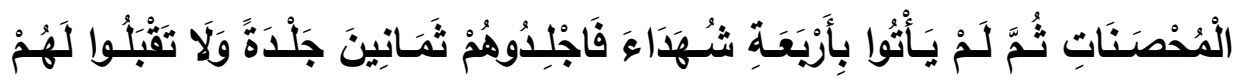

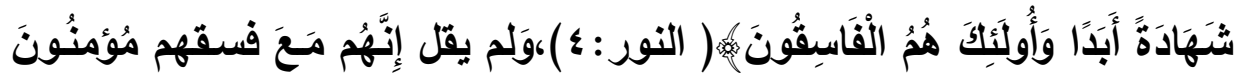

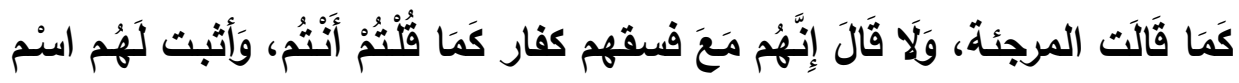
الْفسق فَقَط فهم فسـاق لَا مُؤمنُونَ وَلَا كافرون كَمَا قَالَ الله عز وَجلَ وأجمعت

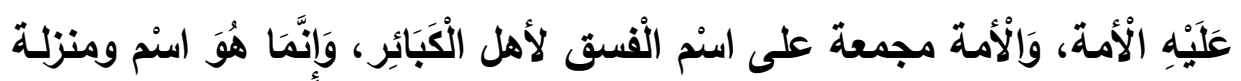

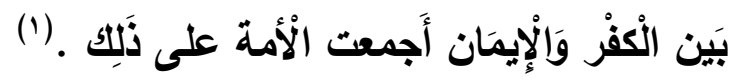

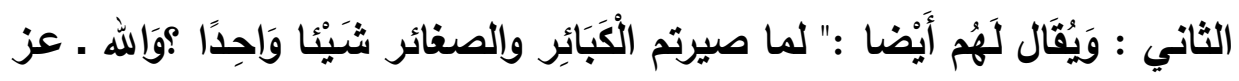

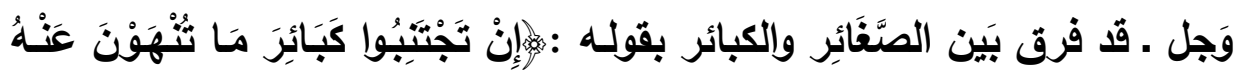

(1) التبيه والرد / للملطي / ع (1)

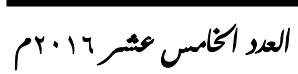

مجلةكليت البنات الإسلميت- جامع: الأهر- في أسيوط 


\section{طائة الأزارقة تاريخها ، وعقائدها}

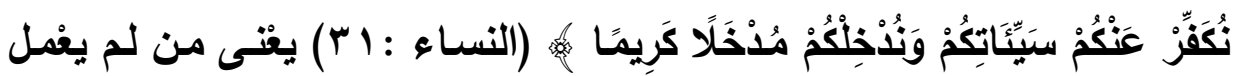

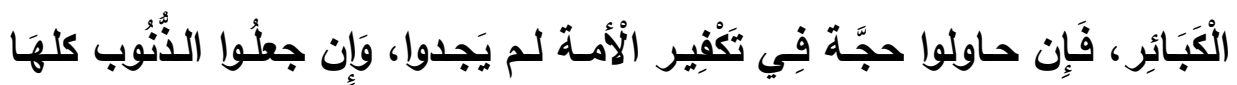

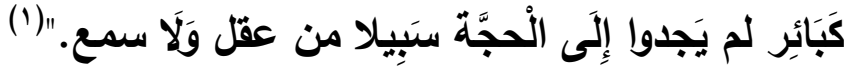

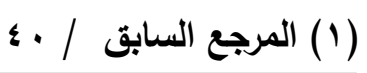




\section{المبمث الثالث}

\section{مقائدهم وآراوفم الفكرية}

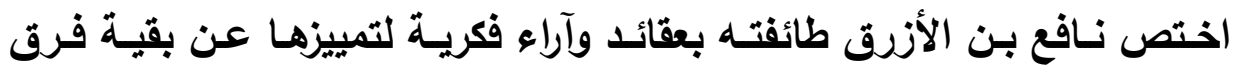

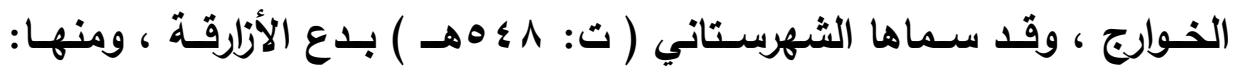

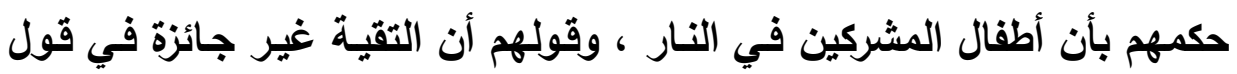

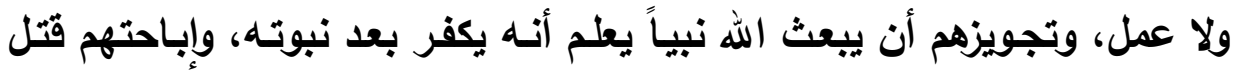

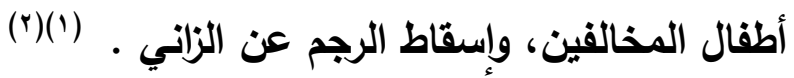
المطلب الأول : حكمه بأن أطفال المشركين في النار مع آبائهم .

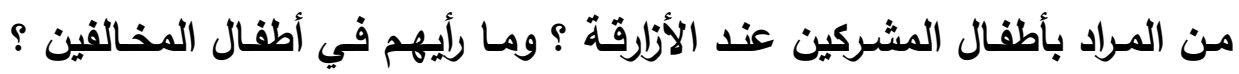
وهل حكموا عليهم بأنهم تبع لآبائهم في الآخرة ؟

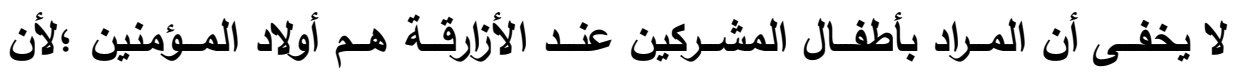
مخالفيهم ـ كما يعتقدون - مشركون فينسحب هذا الحكم على أولادهم .

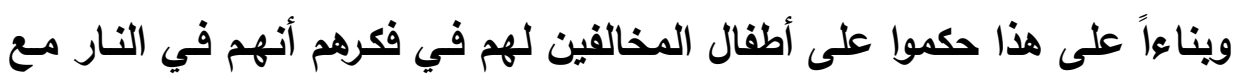

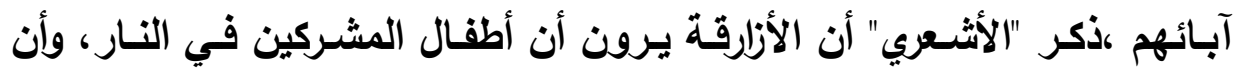

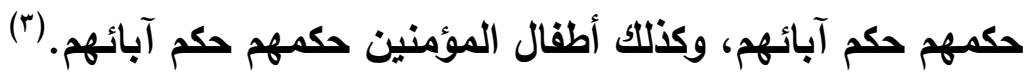

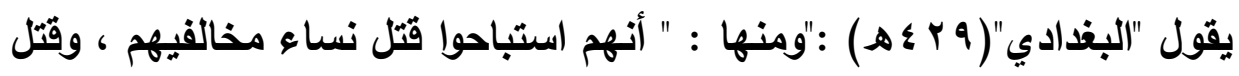

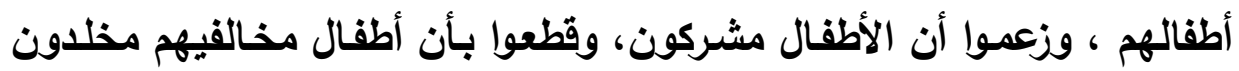

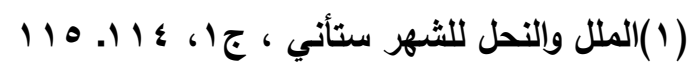

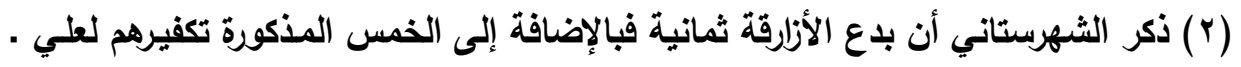
رضب الله عنه ـ وللقعدة، ولمرتكب الكبيرة .

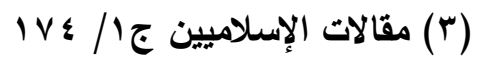

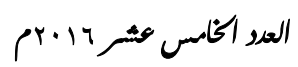

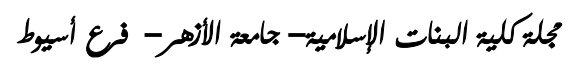


في النار.." (1)

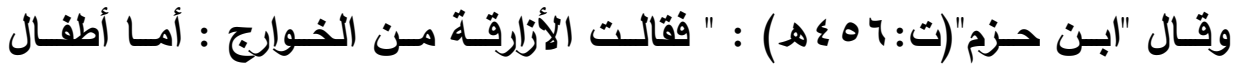

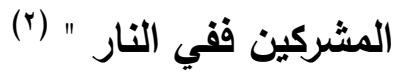

اعتقد "نافع بن الأزرق"(ت:07 هـ) هذا الرأي، ودافع عنه فلما كتب له "تجدة بن

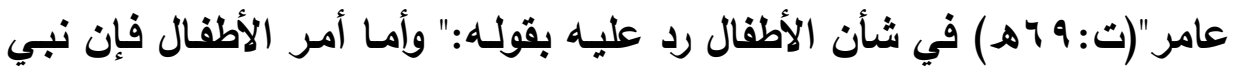

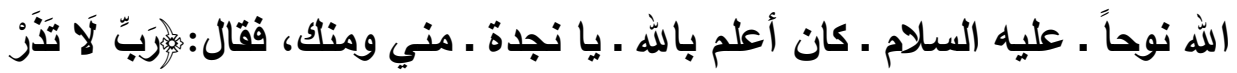
عَلَى الْأَرْضِ مِنَ الْكَافرِِينَ دَيَّارًا أن يولدوا، فكيف كان ذلتك في قوم نـوح ولا نقولـه في قومتـابوالله يقول

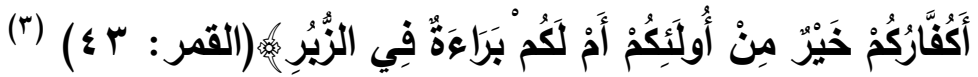
وذكر ابن حزم (ت: ؟ ه ءه) أن الأزارقة احتجوا على ما ذهبوا إليه بأدلة نقلية، وأخرى عقلية لتأيبا رأيهم ويبانه.

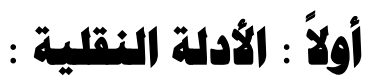

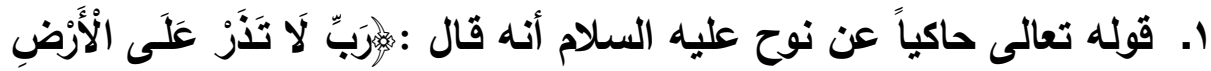

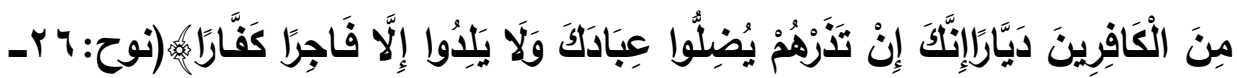

rـ عن أم المؤمنين خديجـة رضـي الله عنهـا قالت: يـا رسـول الله أيـن أطفـالي منك؟ قال في الجنة ـ قالت : فأطفالي من غيرك ؟ قال في النار . فأعادت عليه

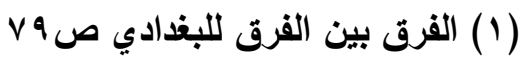

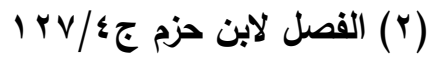

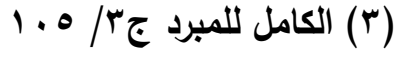

العر الخام عشر 17.

مجلةكليت البنات الإسلميت- جامع: الأهر- في أسيوط 


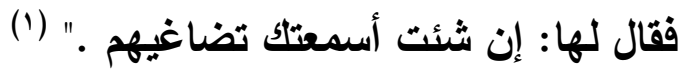

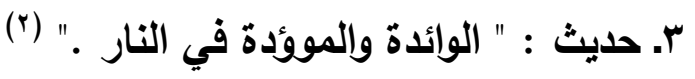 \\ ثانيا : الألدلة العقلية :}

قالوا إن كانوا عندكم في الجنـة فهم مؤمنـون ، لأنـه لا يـلـخل الجنـة إلا نفس

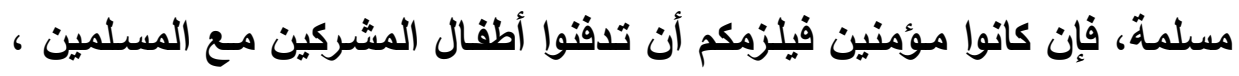

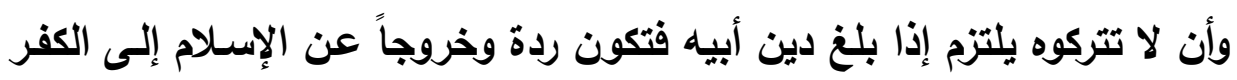

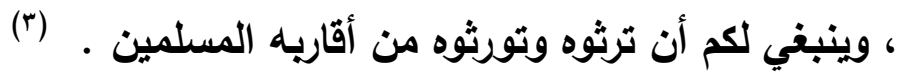

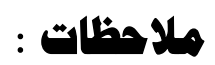

وينقض ما ذهب إليه الأزارقة من أن أطفال المشركين في النار مـع آبائهم مـا يلي : أولاً : توافر النصوص الصريحة الصحيحة بأن أطفال المسلمين في الجنة ومنها ا. عن أنس بن مالك رضي الله عنه قال: قال النبي

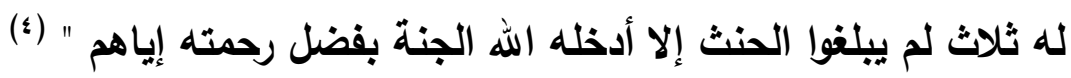

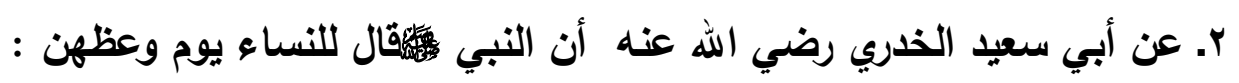

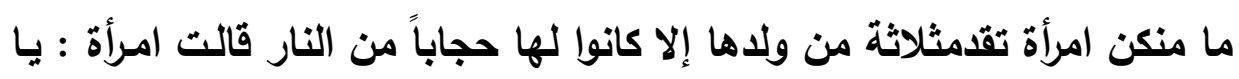

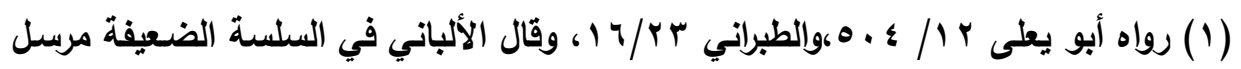
צ

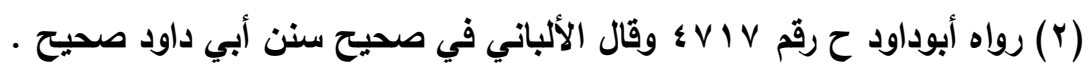

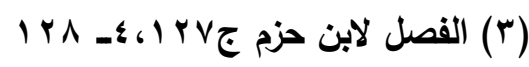

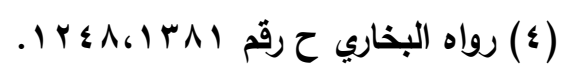

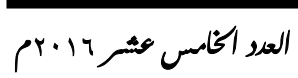

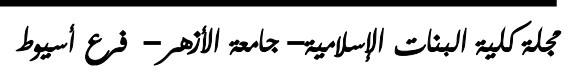
(49 
رسول الله وإثنين؟ فقال: واثثان " (1) r. عن أبي هريرة رضي الله عنه عن التبي

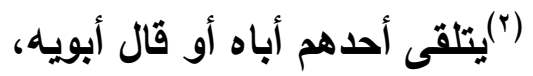
فيأخذ بثويه كما آخذ أنـا بصنفة ثويك هذا، فلا ينتهي حتى ياخله الله وأبويـه

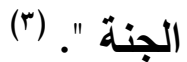

ثانيـاً : أن القـول بـأن أطفـال المسـمين في الجنـة هـو المعروف مـن قواعد

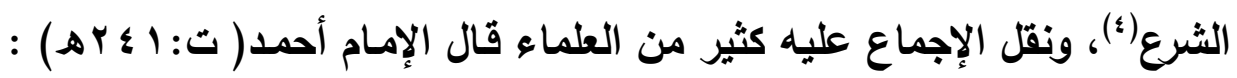

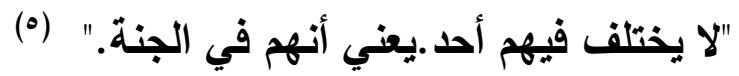
وقال ابن عبد البر ( ت : بآ ءهـ):"قد أجمع العلماء على مـا قلنا من أن أطفال المسـلمين فـي الجنـة، فـأغنى ذلــك عـن كثيـر مـن الاسـتـلال، ولا أعلـم عـن جماعتهم في ذلك خلافاً إلا فرقة شذت من المجبرة فجعلتهم في المشيئة، وهو قول شاذ مهجور مردود بإجماع الجماعة، وهم الحجة الأين لا يجوز مخالفتهم،

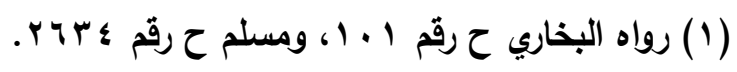

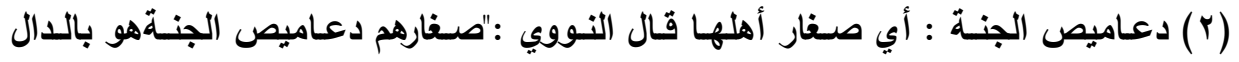

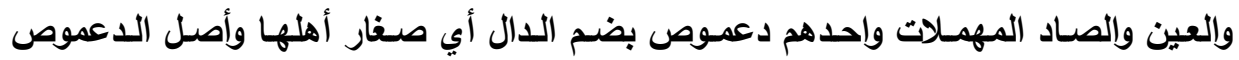
دويبة تكون في المـاء لا تفارقه أي أن هذا الصغير في الجنـة لا يفارقها. ( شرح صحيح

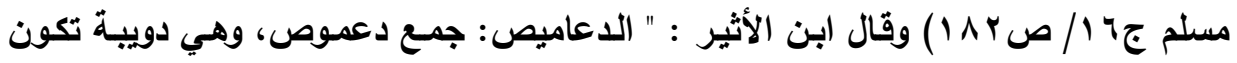

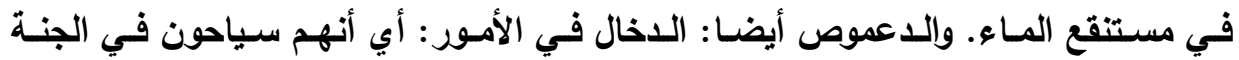

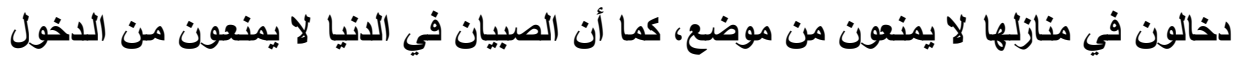

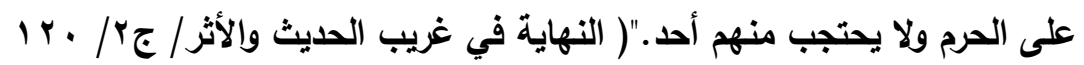

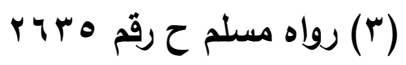

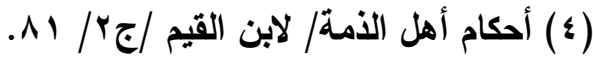

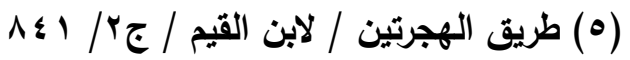

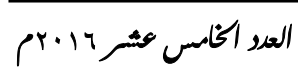

مجليكليي: البنات الإسلميت- جامع: الأهر- فئ أسيوط 
ولا يجوز على مثلهم الغلط في مثل هذا إلى ما روي عن النبي صلى الله عليه

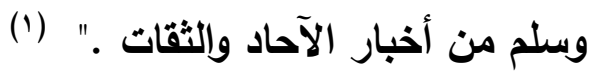

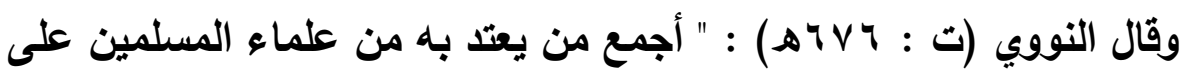

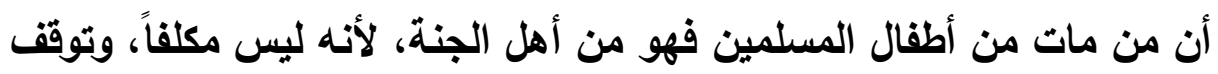

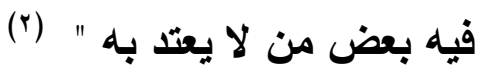

\section{الإلب الثثاني}

\section{قولهم إن التقية غير جائرة في قول ولا عمل .}

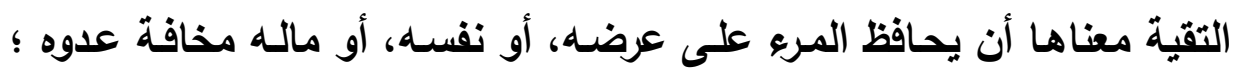

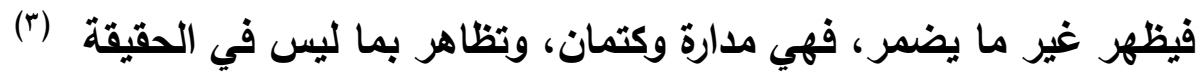
وقد ذهب أهل السنة إلى أن التقية هي حذر المسلم من إظهار ما في نفسه من ونان

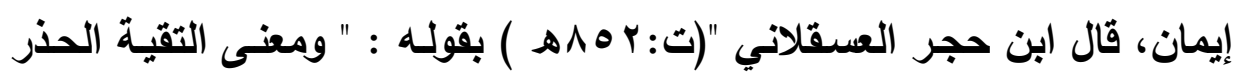

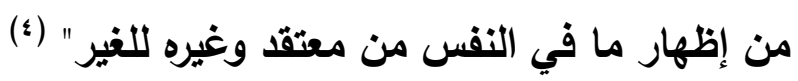
وقال الإمام العيني (ت: هـ1هـ) :" التقية هي الحذر من من إظهار ما في في الضمير

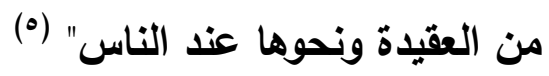

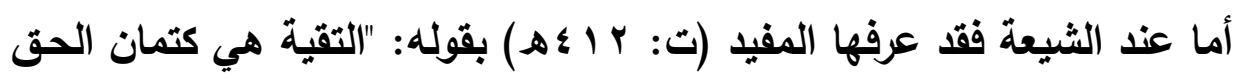

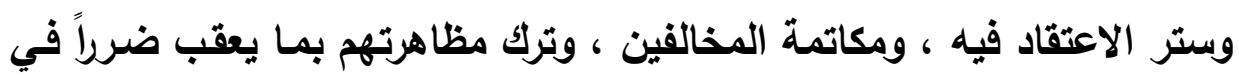

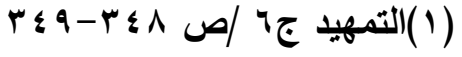

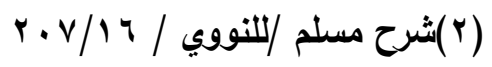

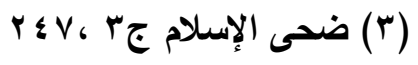

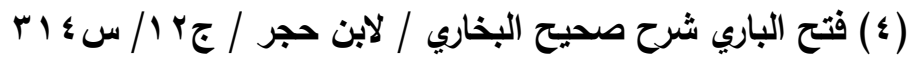

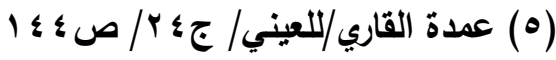

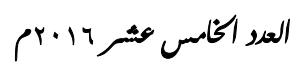

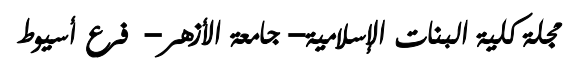
(4V... 
الدين أو الانيا ." (')

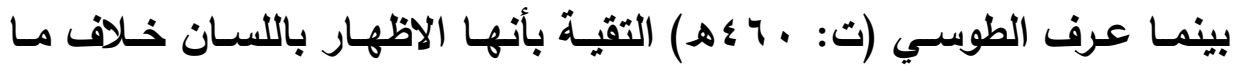

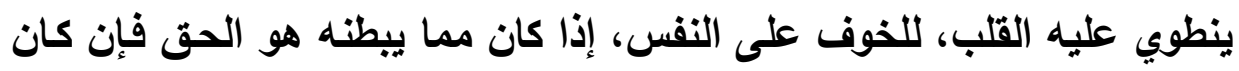

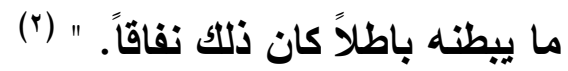
ولا يخفى أن المراد بالمخالفين عند أهل السنة هم أهل الكفر، أما عند الثيعة فإنهم يطلقون لفظ المخالقين ويريدون به أهل السنة. وقد ذهبت الإباضية الخوارج إلى أن التقية نظام سري لله غايات مقصودة، فقد

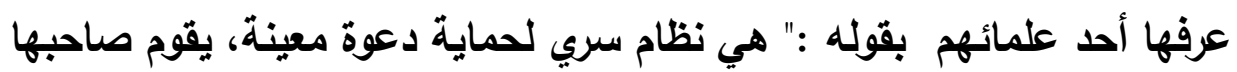

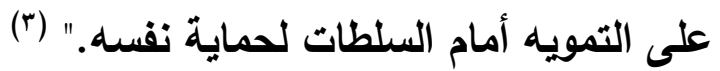

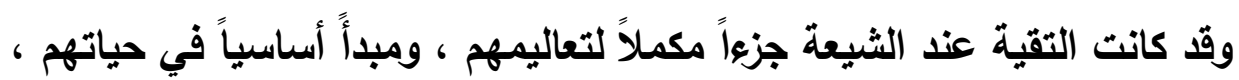

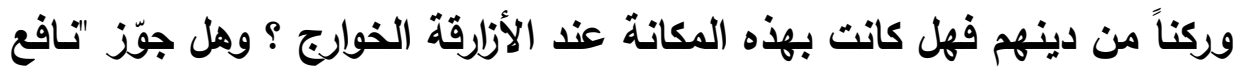

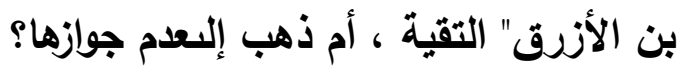

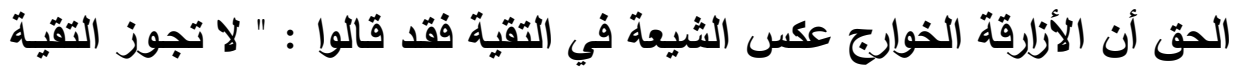

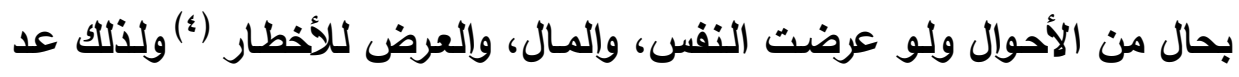

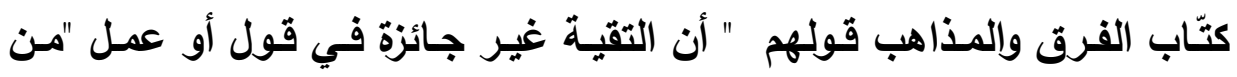

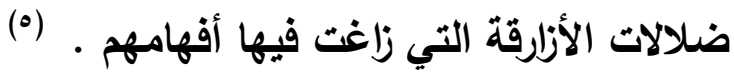

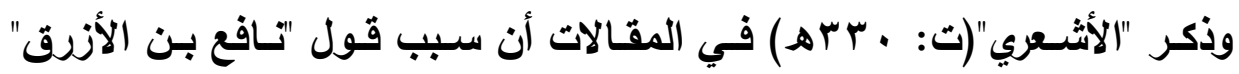

$$
\begin{aligned}
& \text { (1)شرح عقائد الصدوق صبr) }
\end{aligned}
$$

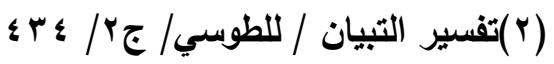

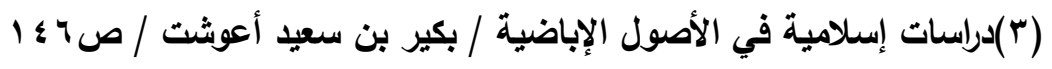

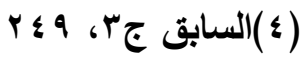

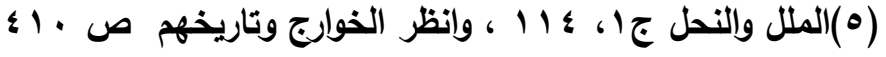

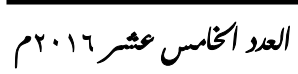

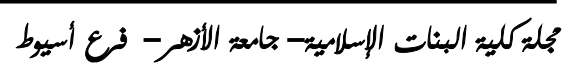
(4V.1) 
بالتقية يرجع إلى :"أن امرأة من أهل اليمن عربية ترى رأي الخوارج تزوجت رجلاً

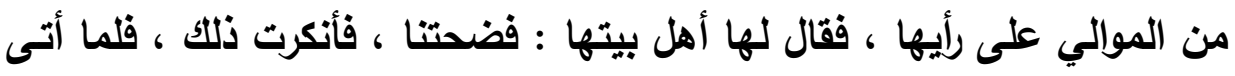

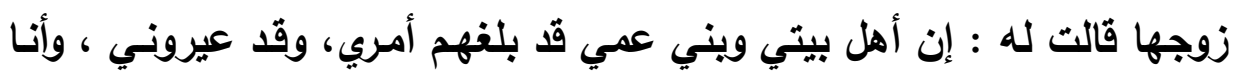

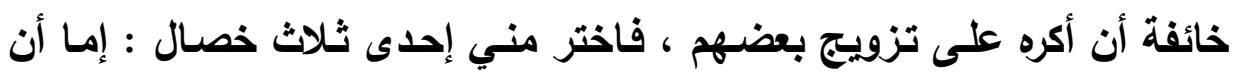

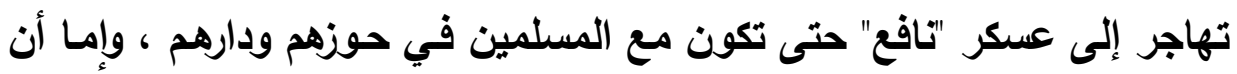

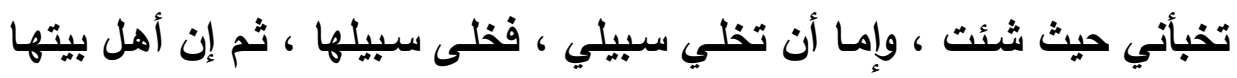

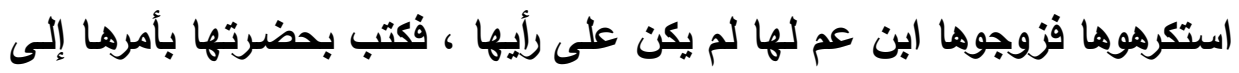

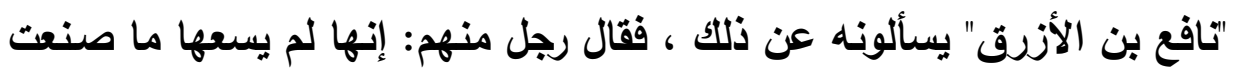

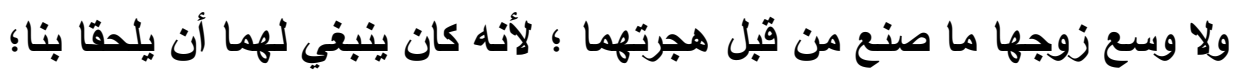

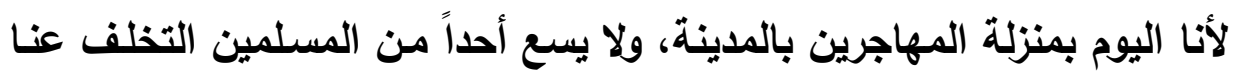

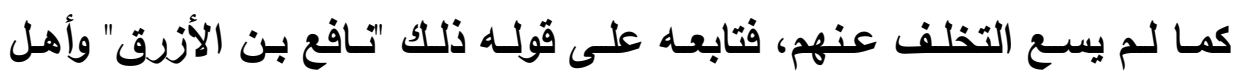

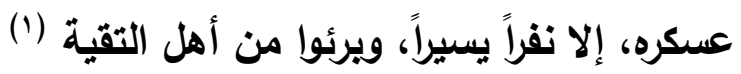

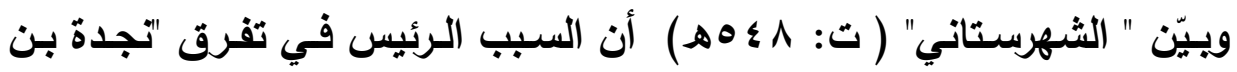

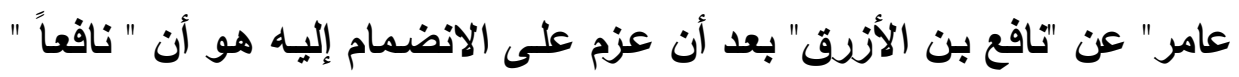

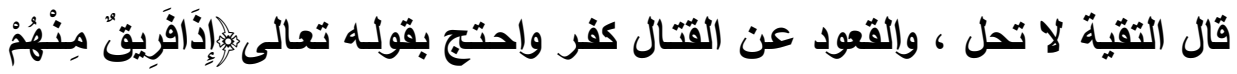

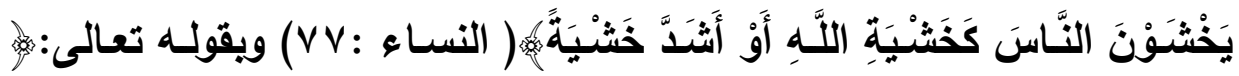

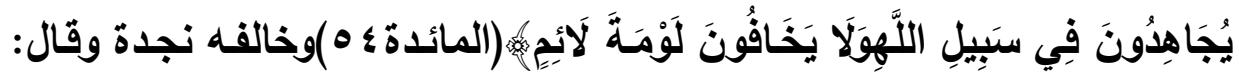

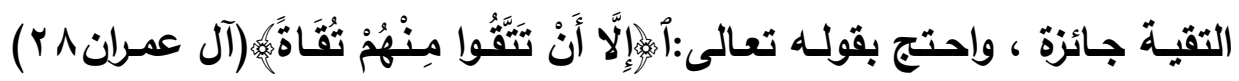

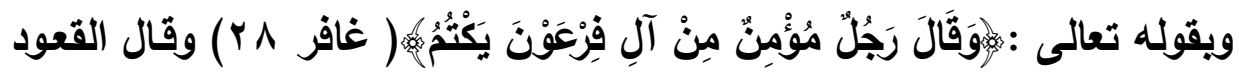

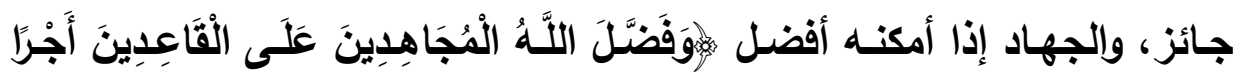

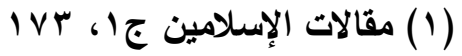

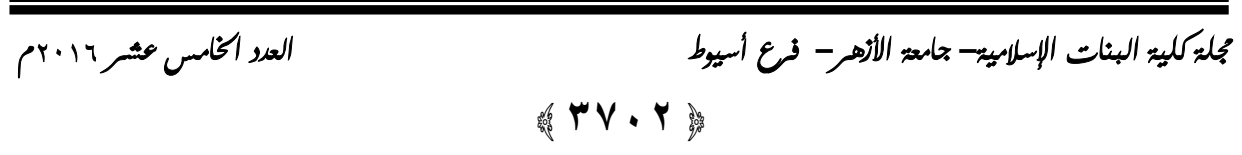




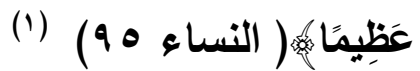

ورد "تافع بن الأزرق" على استدلال نجدة بقولـه :" هذا في أصحاب النبي . صلى الله عليه وسلم . حين كانوا مقهورين ، وأما في غيرهم مع الإمكان فالقعدة

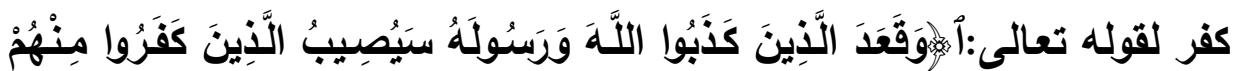

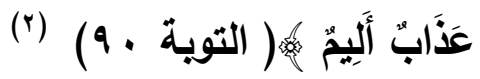

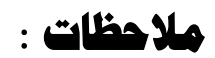

أولاً : ما ذهب إليه الأزارقة من القول بتحريم التقيـة يعد انحرافاً عن الإسـلام،

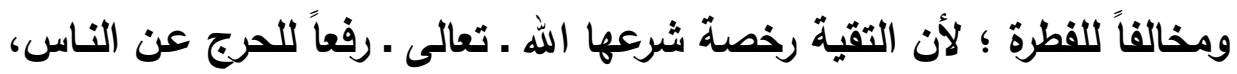

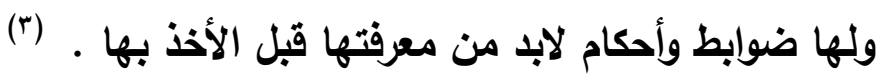

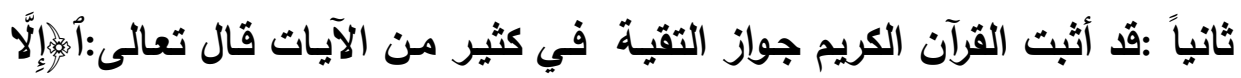

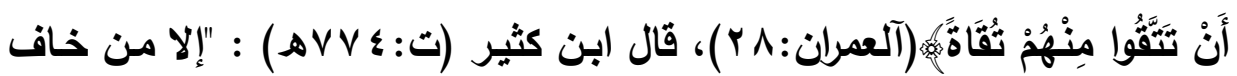
في بعض البلدان والأوقات من شرهم فله أن يتقيهم بظاهره لا بباطنه ونيته"(

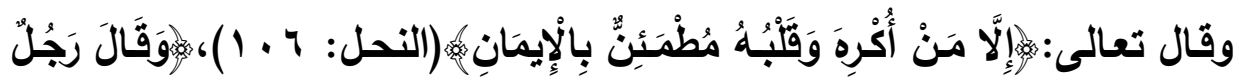

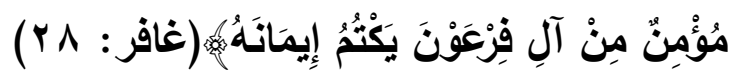

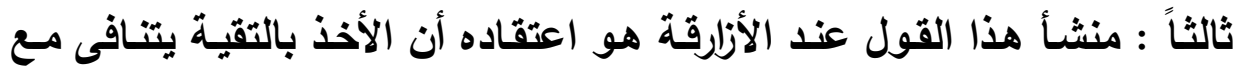
وجوب الجهاد ، ولذلك احتج بالآيات القرآنية التي تؤكد على فرضية الجهاد ، وتحذر من القعود والتخلف عنـه .والواقع أن الإخذ بالتقية لا يتنافى مـع وجوب

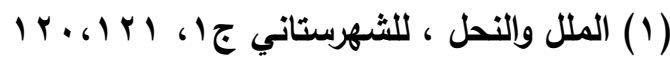

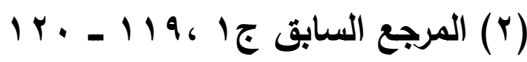

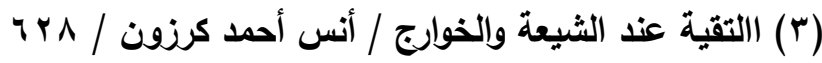

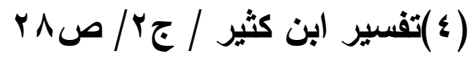$$
\text { العرد اكامس عثر } 17 \text { بrم }
$$$$
\text { مجلةكليت البنات الإسلميت- جامع: الأهر- في أسيوط }
$$ 
الجهاد؛ لأنها رخصة مستثناة من الأصل في حالة الإكراه والخوف. (') المطلب الثالث : إباحته قتل أطفال المخالفين ، وإلنسوان . ويناء على اعتقاد الأزارقة بأن مخالفيهم من هذه الأمـة مشركون فقد استحلوا قتل الأطفال والنساء. وهذاما اعترف به الإباضية فانهم يرون أن نافعاً لم يسبقه هئه أحد بالقول بتشريك المخالفين، واستحلال دماء أطفال مخالفيه. (ז) وأكده "تافع" في مخاطبته مع "تجدة بن عامر" فقال :" وهؤلاء كمشركي العرب لا نقبـل مـهم جزيـة، وليس بينــا ويينهم إلا السـيف أو الإسـلام .وأمـا اسـتحلال أمانات من خالقنا فإن الله . عز وجل ـ أحل لنا أموالهم ، كما أحل لنا دماءهم ،

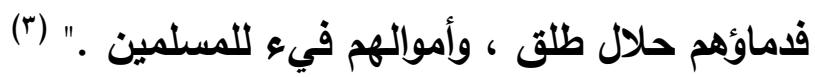
ويرجـع سبب قول الأزارقة بذلك إلى الحوار الذي دار بين "تـافع" ومـولى لبني هاشم جاء إلى "تافع" فقال لـه : إن أطفال المشركين في النار، وإن من خالقتا مشرك فدماء هؤلاء الأطفال لنا حلال ـ قال له نافع : كفرت وأحللت بنفسك .

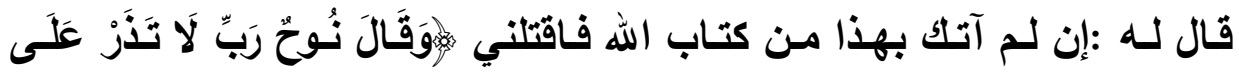

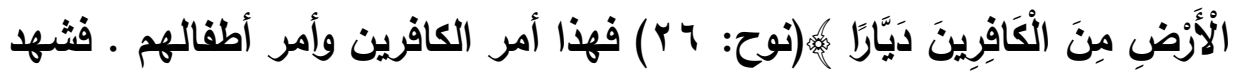
نافع أنهم جميعاً في النار ورأى قتلهم ، ورأى الاستعراض ، وقال الدار دار كفر إلا من أظهر إيمانه، ولا يحل أكل ذبائحهم، ولا تتاكحهم ، ولا توارثهم، ومتى مـا جاء منهم جاء فعلينا أن نمتحنه ، وهم ككفار العرب ، لا نقبل منهم إلا الإسـلام

أو السيف (ء) هن

(1) التقية عند الثيعة والخوارج / أنس أحمد كرزون / • r آج

$$
\begin{aligned}
& \text { (r) (r) }
\end{aligned}
$$

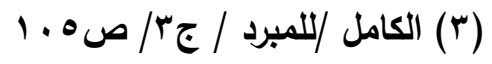

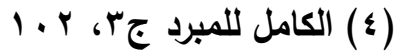

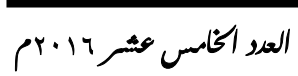

مجلةكليت البنات الإسلميت- جامع: الأهر- في أسيوط 


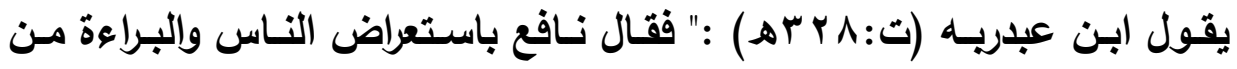

"عثمان" و "علي" و"طلحة" و"الزبير" واستحلال الأمانة وقتل الأطفال " ( )

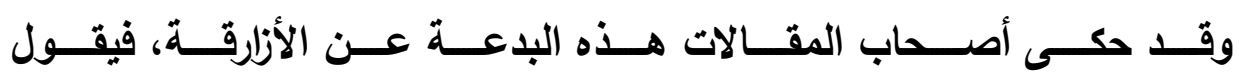

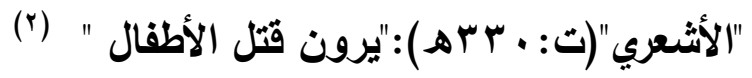

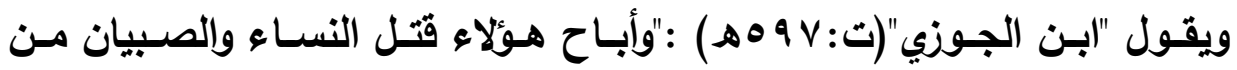

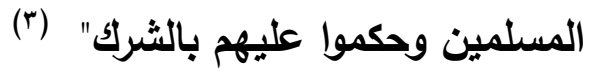

تمقمبـب:

لا شك أن قتل الأزارقة للأطفال والنسـاء خاصـة يخالف هدي النبي ـ صلى الله عليه وسـلم . ، ويتـافى مـع سماحة الإسـلام ، وقد تصدى سـلف الأمسة لإبطال

مذهبهم الضال في استحلال الدماء ، ودفعوا شبهتهم بوجوه ، منها : الأول : يدفع قول الأزارقة في استحلال الدماء نهي النبي ـ صلى الله عليه

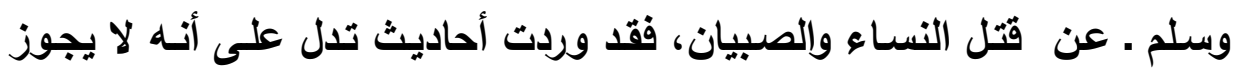
قتل النساء والصبيان منها: اـ عن سليمان بن بريدة عن أبيه أن النبي ـ صلى الله عليه وسلم ـ قال : " اغزوا باسم الله وفي سبيل الله ، وقاتلوا من كفر بالله، اغزوا ولا تغدروا ، ولا

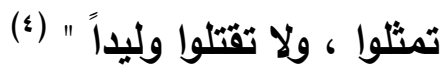

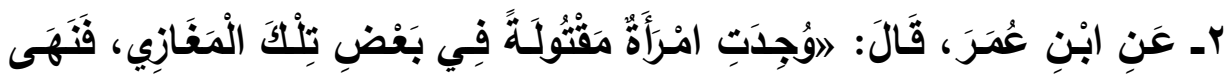

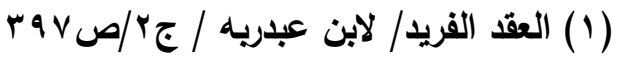

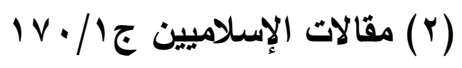

$$
\begin{aligned}
& \text { 9 }
\end{aligned}
$$

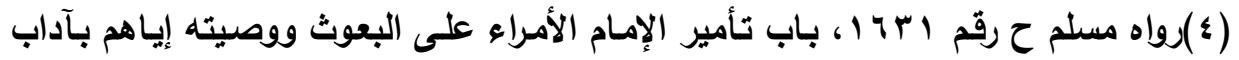
الغزو وغيرها

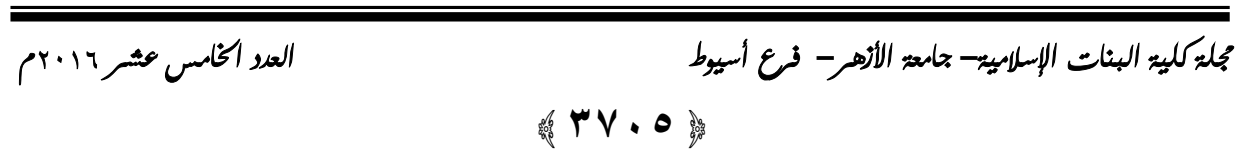




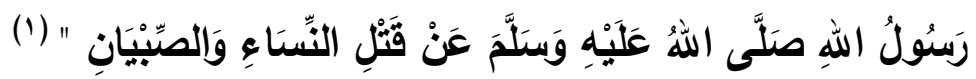

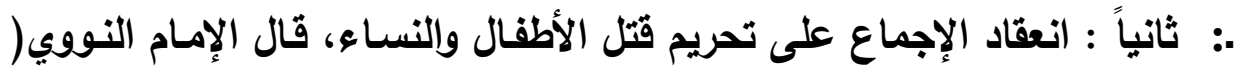

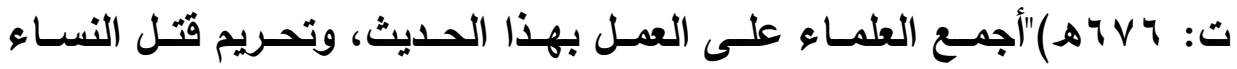

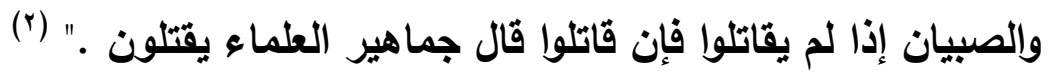

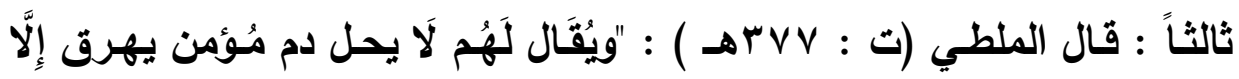

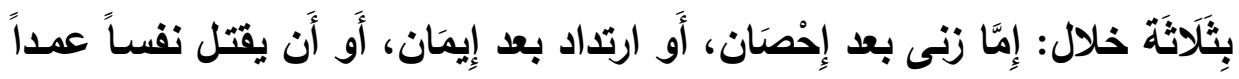

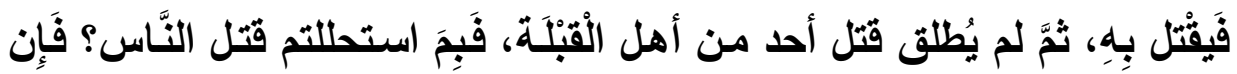

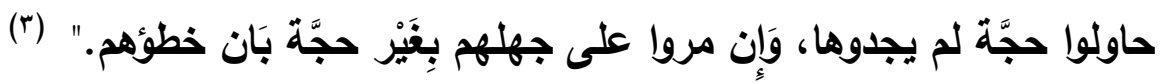

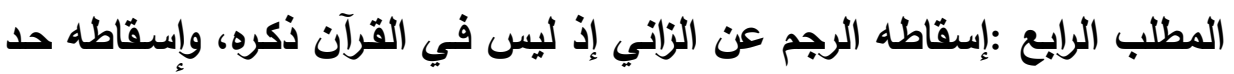

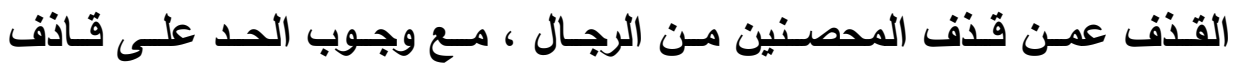

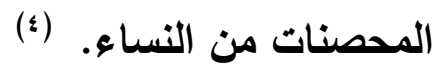

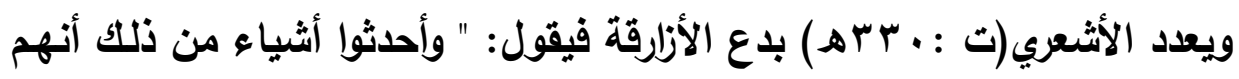

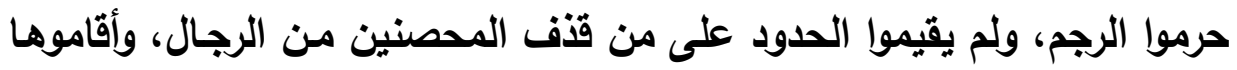

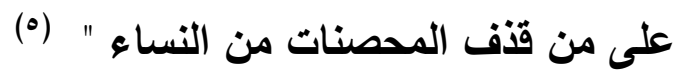

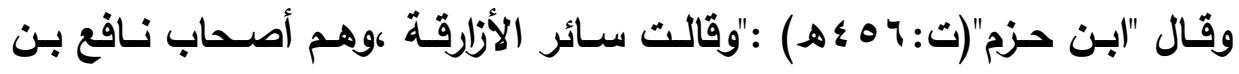

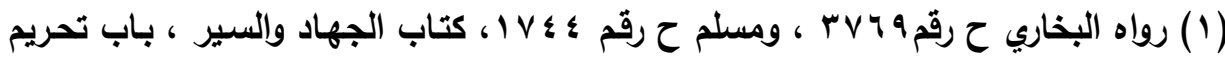
قتل النساء والصبيان في العرب

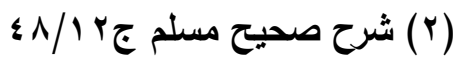

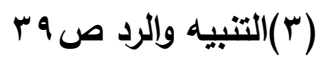

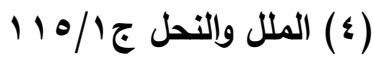

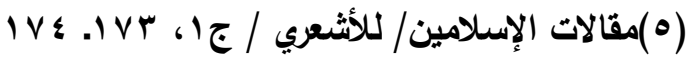

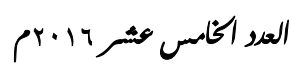

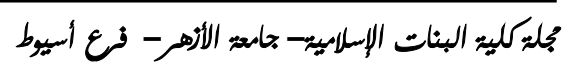
( $r V \cdot T)$ 
الأزرق بإبطال رجم من زنى وهو محصن ." (1)

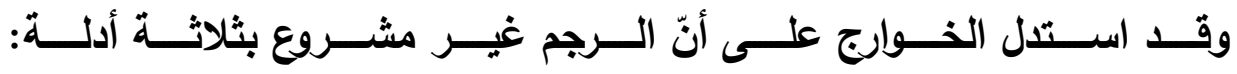

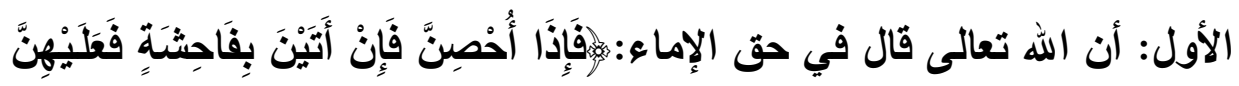

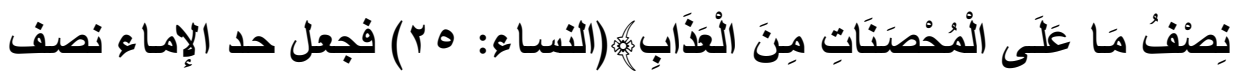

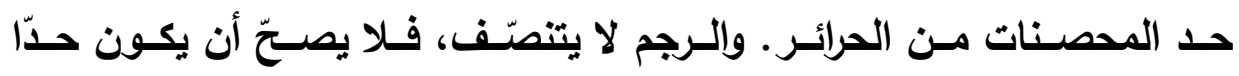
للمحصنات من الحرائر . الثاني: أن الله ـ تعالى ـ فصّل أحكام الزنى، وأطنب فيها بما لم يطنب في غيرها،

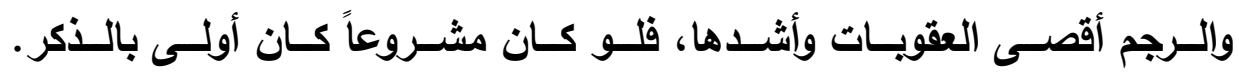

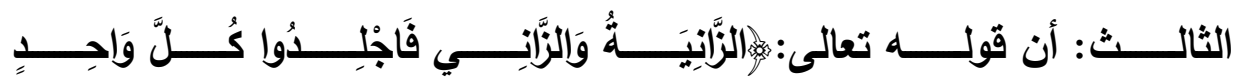

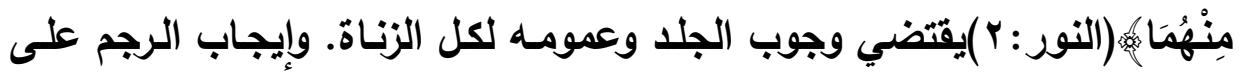

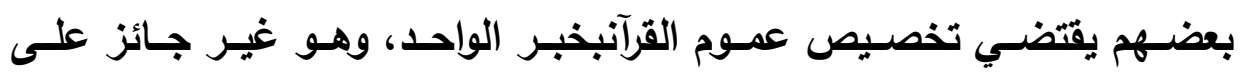

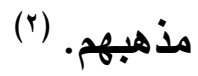
تعقيب : أجاب الجمهور على أظلة الخوارج بما يلي :

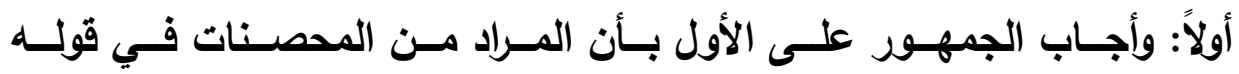

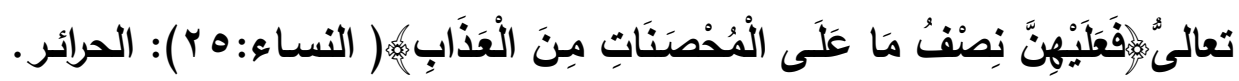
،والحرائر نوعان: ثيبات وأبكار، وحد النوعين على التوزيعي: الرجم وجلد مئسة،

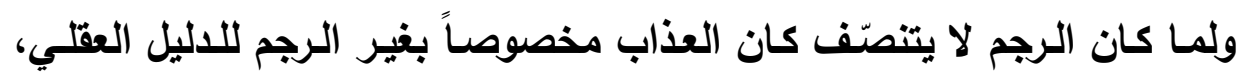
وكان الرجم غير مشروع في حق الأرقاء.

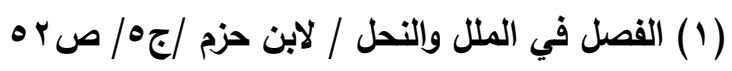

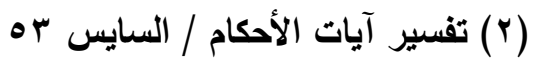

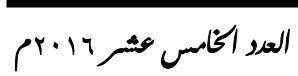

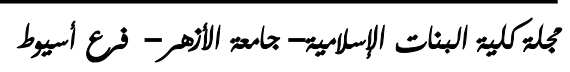
(4) $r v \cdot V$ 
ثانياً : وعن الثاني بأن الأحكام الثرعية كانت تنزل بحسب تجدّد المصالح، فلعل المصلحة التي اقتضت وجوب الرجم حدثت بعد نزول هذه الآيات، وكفى الآن بالسنة ـ ووظيفتها البيان والتكميل - بياناً وتفصيلاً. ثالثاً :وعن الثالث بأنّ تخصيص عموم القرآن بخبر الواحد جائز عندنا، لأنّ والثي

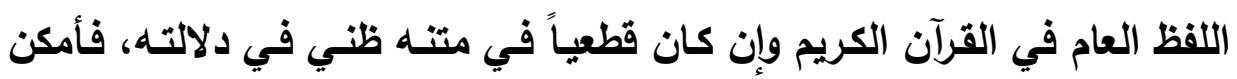

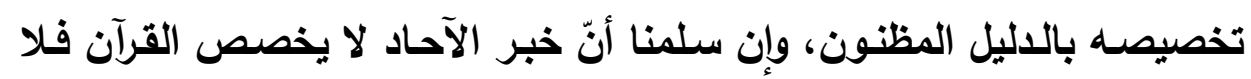

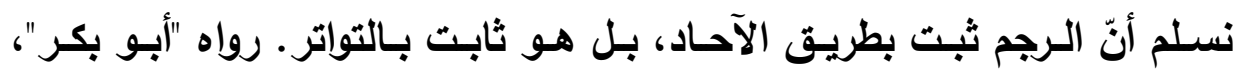

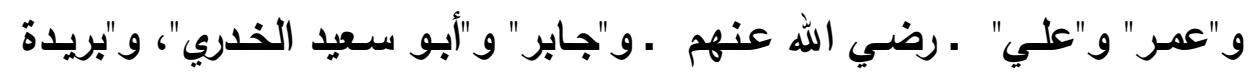

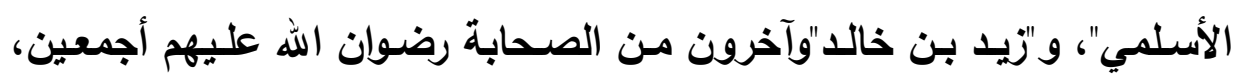

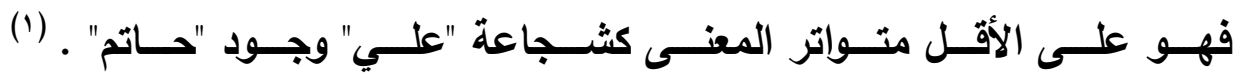

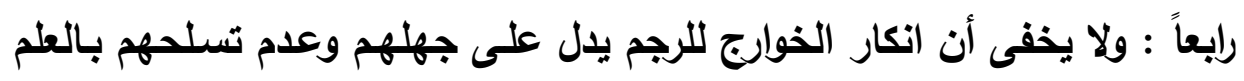

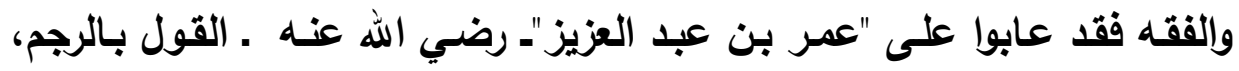

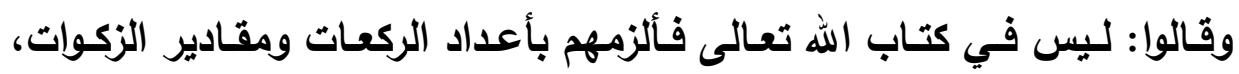

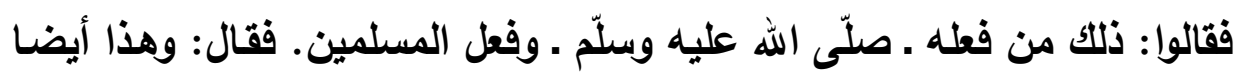

كنلك. (ץ)

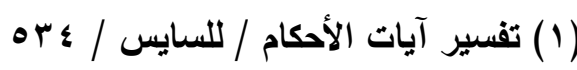

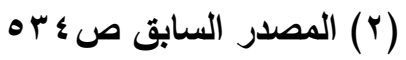

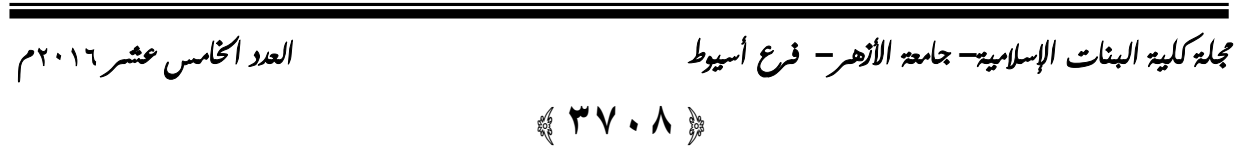




\section{الإلب الخامس}

\section{تجويزه أن يبعث الاله ـ تعالى ـ نبيكا يعلم أنه يكثر بعد نبوقه

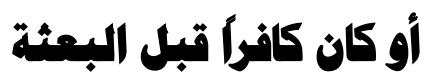

والكبائر والصغائر إذا كانت بمثابة عنده وهي كفر، وفي الأمسة من جوز الكبائر

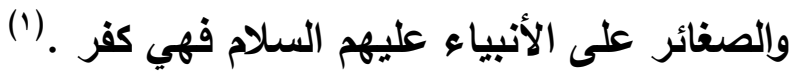

وهذه دعوى باطلة دفعها علماء الأمة وأبطلوها، بما يلي :

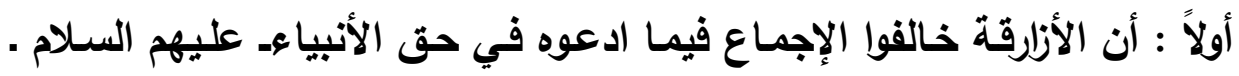

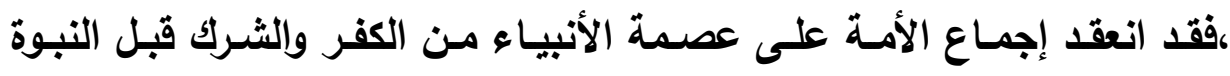

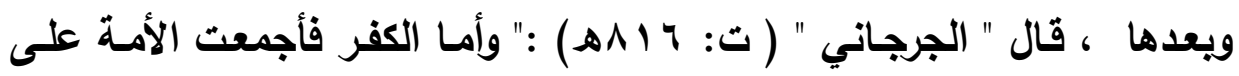

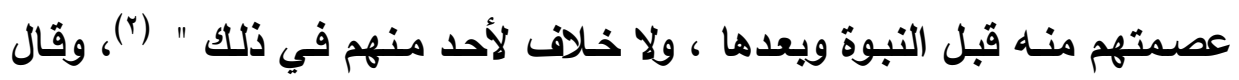

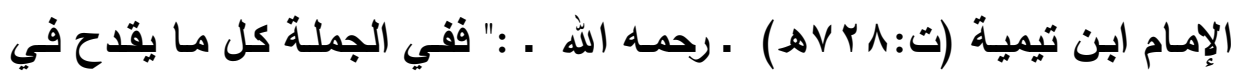

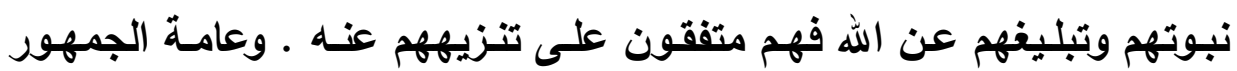

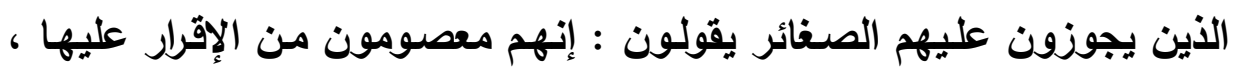
فلا يصدر عنهم ما يضرهم . (r)

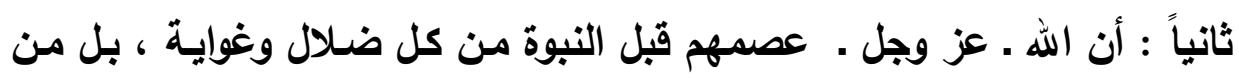

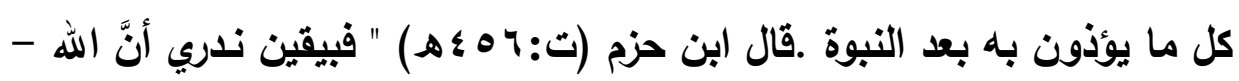

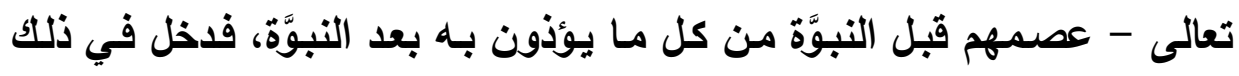

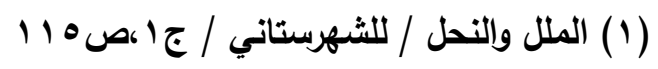

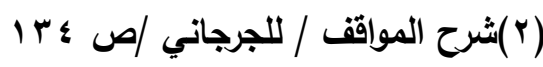

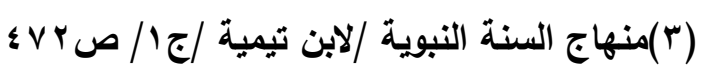

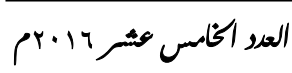

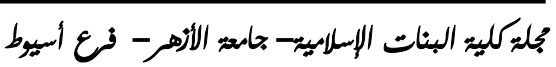
(4V.9. 
اللتَرقة والعدوان، والقسـوة والزنـا، واللّيّاطة والبغي، وأذى النَّاس في حريمهر

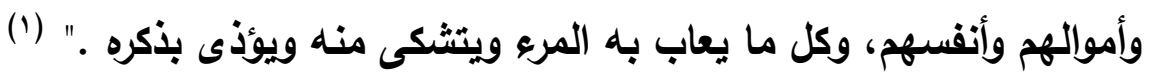
ثالثاً : أن العصمة من الكبائر والمويقات ثابتة للأنبياء ـ عليهم السـلام ـ قبل فئل

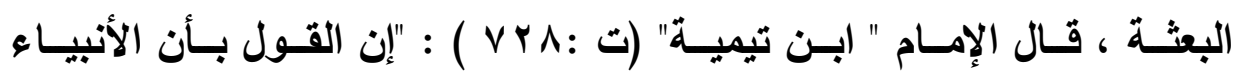

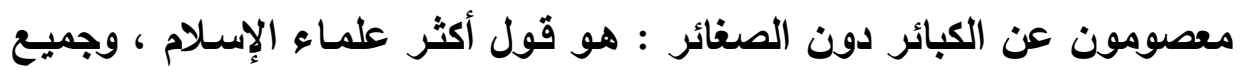

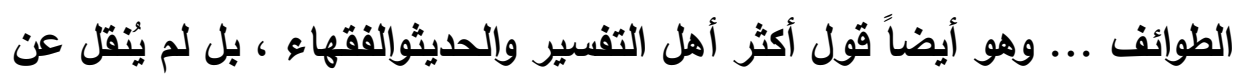

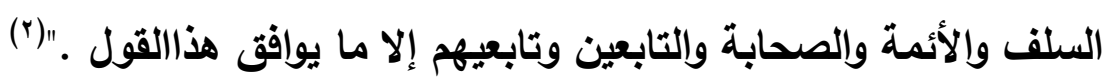

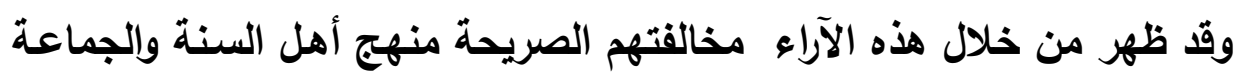

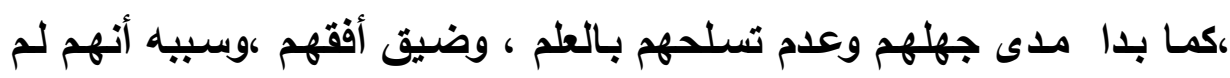

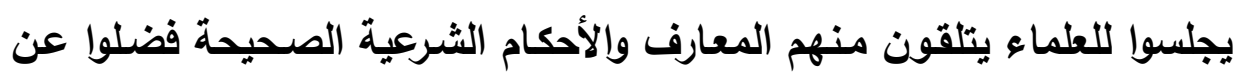
سبيل الهاى والرشاد.

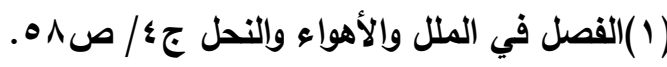

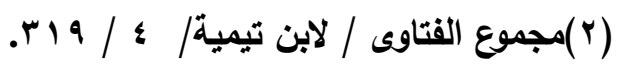

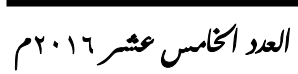

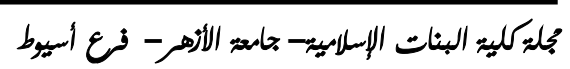
(r) 


\section{الابحث الرابع}

\section{أثر طائفة الأزارقة في البماعات المعاصرة}

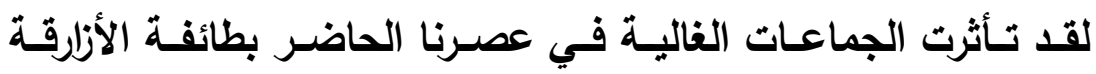

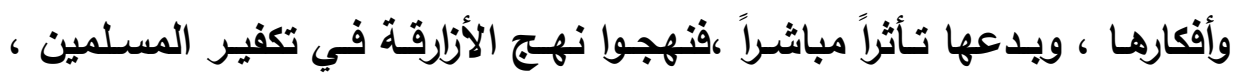

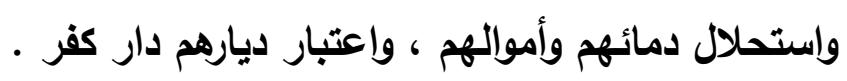

،ققد اتخذ الجماعات في العصر الحديث هذه البدع مرتكزات فكرية لهم،

وأصولاً اعتقادية بنوا عليها نظرتهم للفرد والمجتمع .

وياتت هذه البدع ركائز أساسية يقوم عليها منهج جماعـة "التكفير

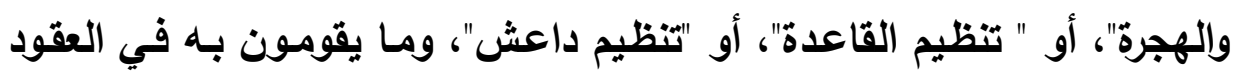

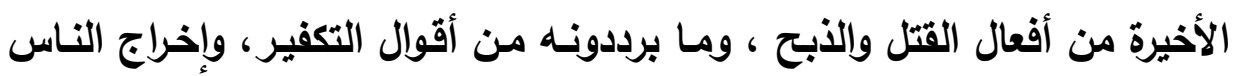

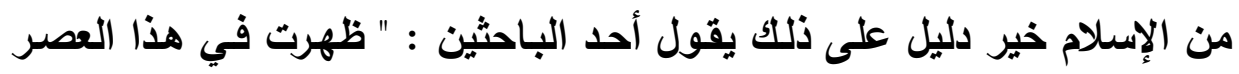

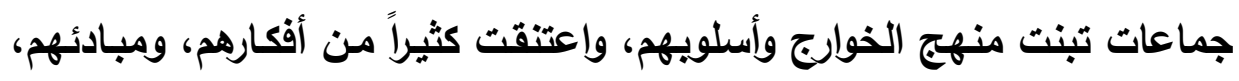

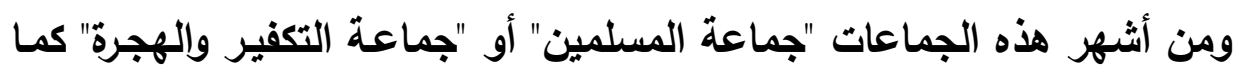

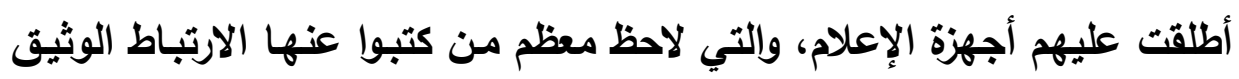

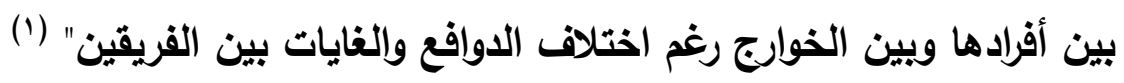
ويمكن أن نلمح أثر اعتقادات الأزارقة في الجماعات المعاصرة فيما يلي

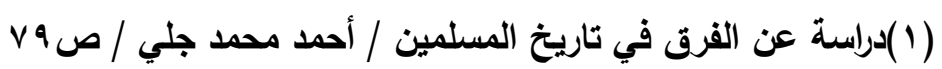

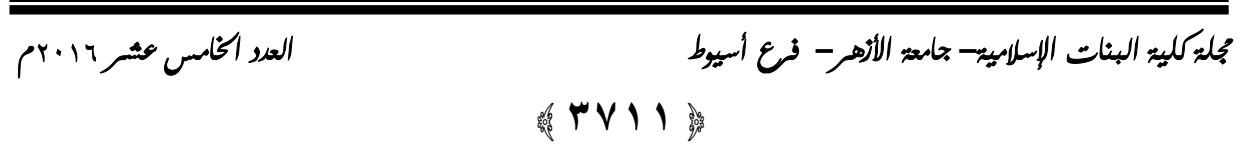




\section{الإطبا الأول}

\section{التكفير}

وقد بدا أثر بدعة التكفير عند الأزارقة واضحاً في العصر الحديث ؛إذ خرج من

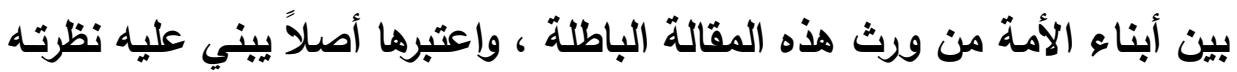
للأفراد والمجتمعات ـ ومن ثم بلت صور التكفيز واضحة في منهج الجماعات الغالية ومنها : الأل ولمجئمات

الأولى : تكفير مرتكب الكبيرة ،فقد أجمع الأزارقة على أن من ارتكب كبيرة من

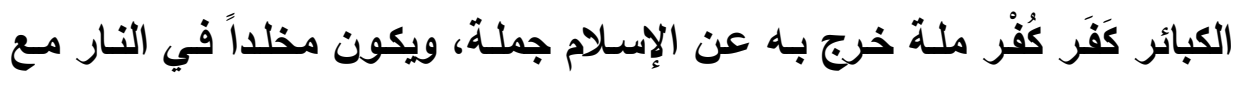
سائر الكفار (') الكيائر كئر وهذا ما اعتقده غلاة التكفيرفي العصر الحديث ؛ وذلك لأنهم نظروا إلى العمل

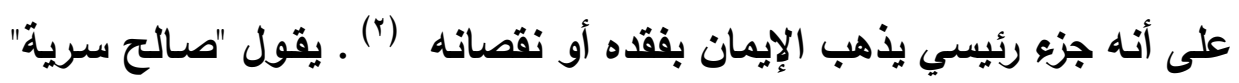

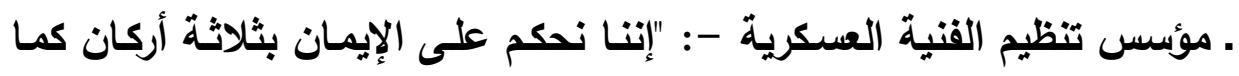

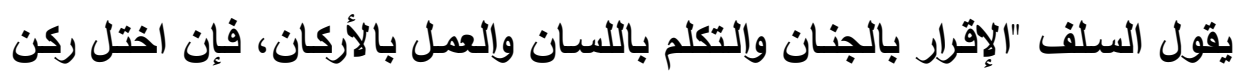

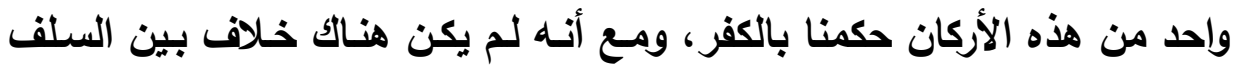

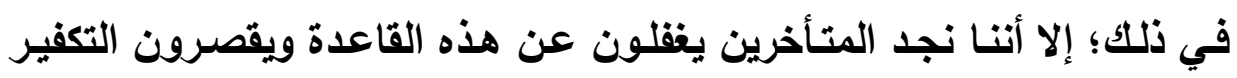

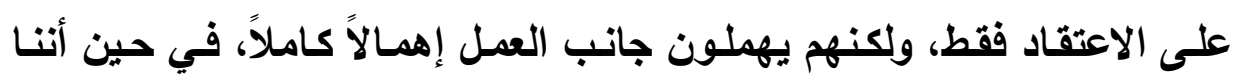

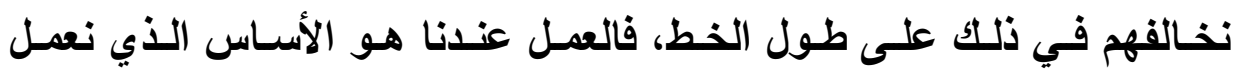

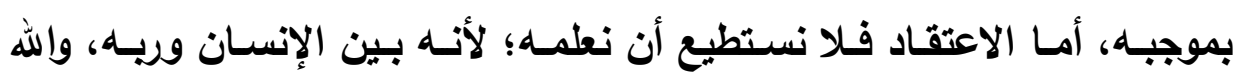

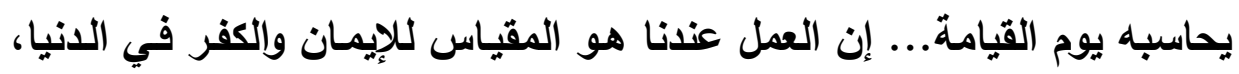

$$
\text { الملل والنحل / للشهرستاني /ج / / ص } 10
$$

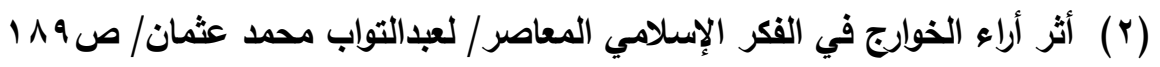

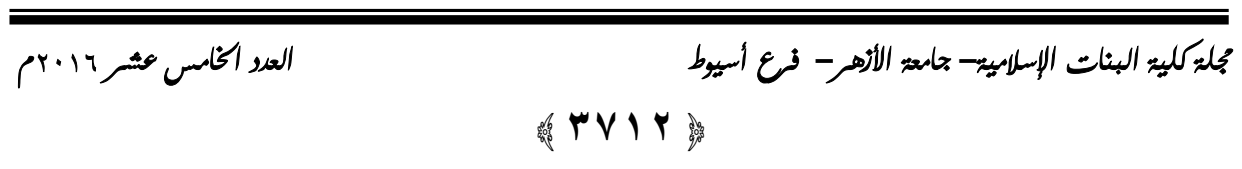


أما الاعتقاد الاخلي فلا نعلمه والله يتولاه يوم القيامة" (1)

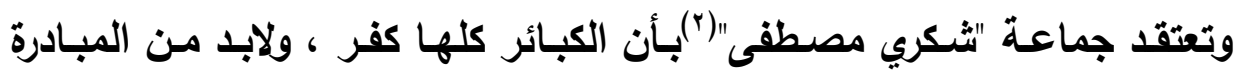

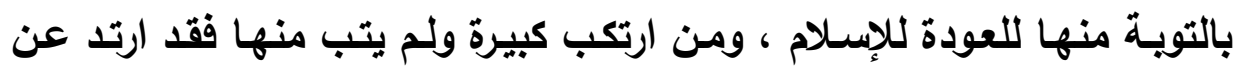

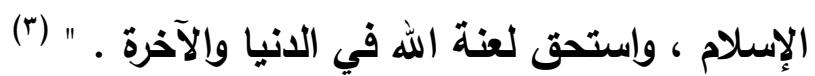

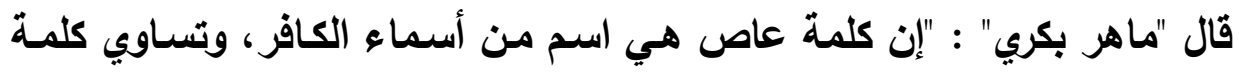

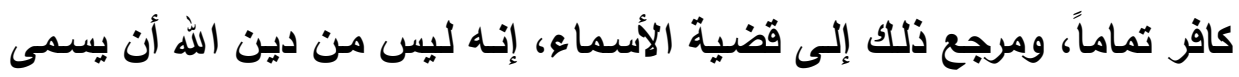

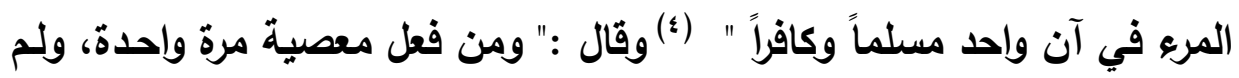

يتب من هذه المرة فهو مصر عليها كافر" (•).

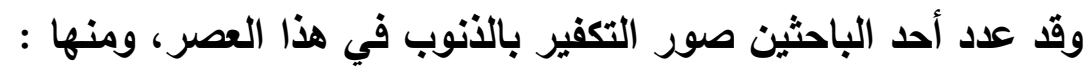

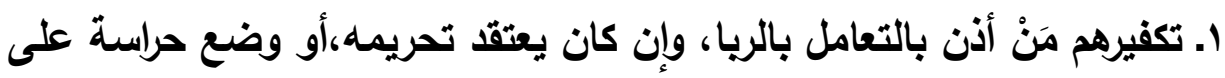

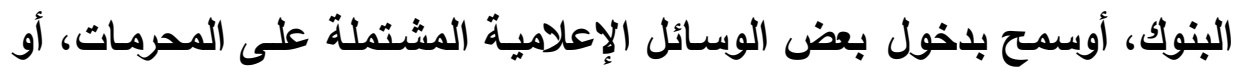

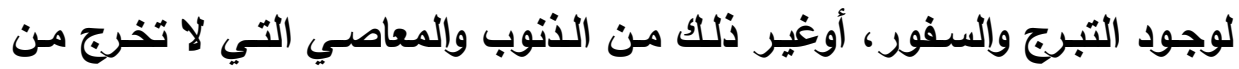
الملة . المجاد

r. أن هم يكفرون بالحكم بغير مـا أنزل الله على الإطلاق، فيجعلون حكم ذلك

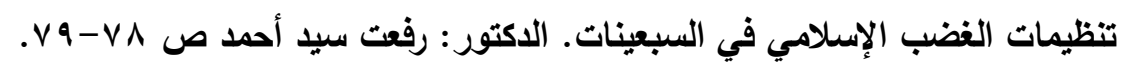

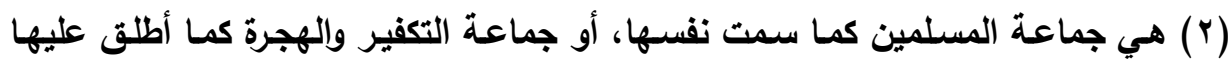
إعلامياً، كونها شكري مصطفى في أوائل السبعينيات

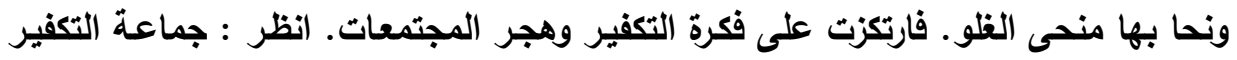

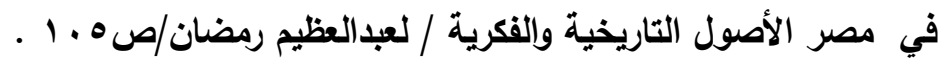

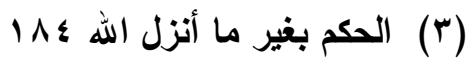

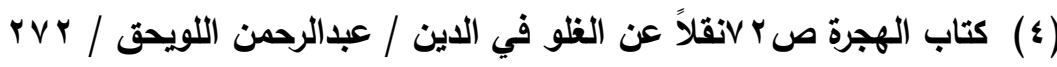

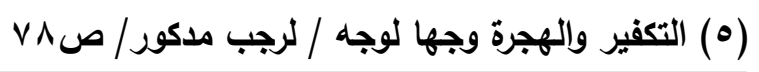

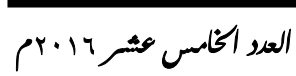

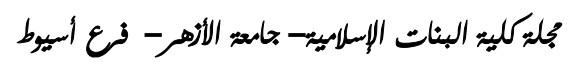

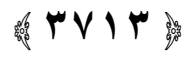


كله واحداً من غير تفصيل rـ ومـن صسور التكفير عند الأزارقة المعاصرين أنهم قد يكفرون المسـلمين

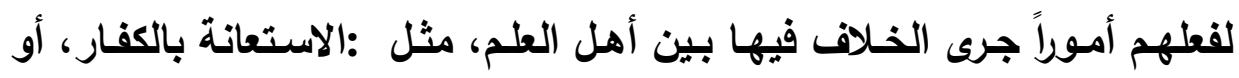
بعض صور المعاملات والمسائل المختلف في حرمتها بين أهل العلم المعتبرين،

ونحو ذلك. (1)

الصورة الثانية : تكفير المخالفين لهم واعتبار دارهم دار كفر ، قال "تافع بن

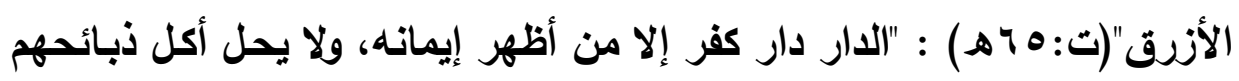

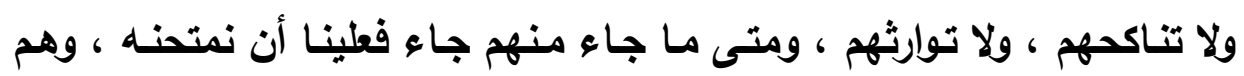

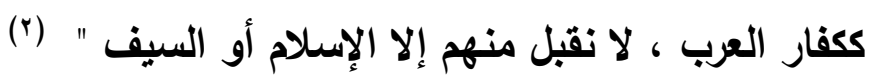

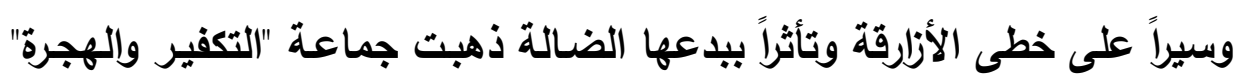

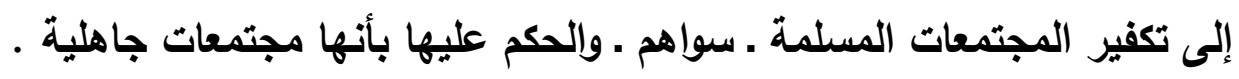

ويرى "أهل التوقف"(؛) أن الناس ساكتون على الحكم بغير مـا أنزل الله ، ولههذا

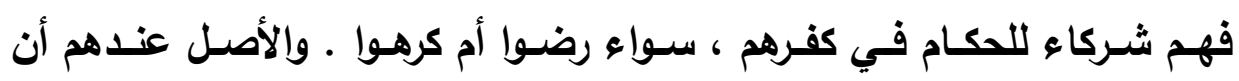

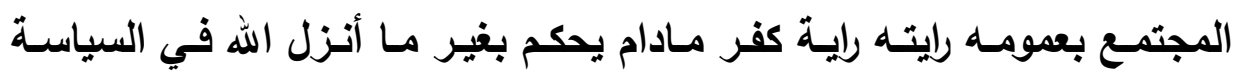

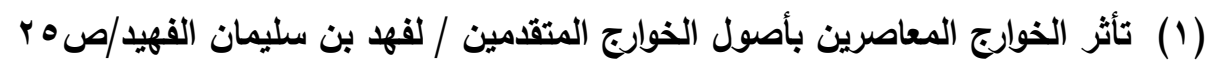

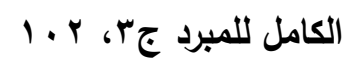

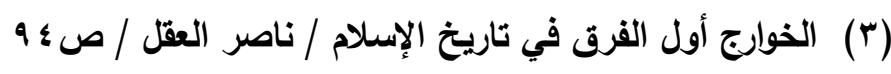

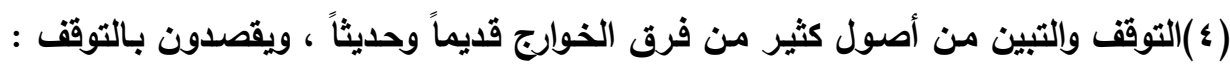

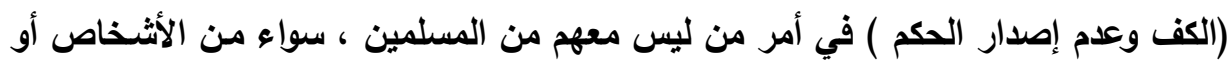
الجماعات أو الهيئات ، من حيث : الإسلام أو الكفر ، والولاية أو البراءة ، حتى يتى يتبين حاله الهن أو تقام عليه الحجة الجمات ، أنات

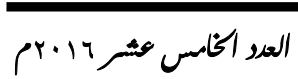

مجليكليي البنات الإساليي- جامعء الأهر- فع أسيوط 


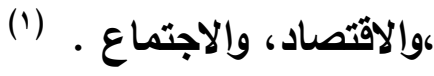

ويزعمون أن " المجتمع جاهلي لا يختلف عن الجاهلية التي عاصرها المصطفى ـ صلى الله عليه وسلم . ، وديارنا ديار حرب، والناس ـ كل الناس ـ كفار مرتدون

إلا من علموا كفره بالطاغوت " (r) ويصل التأثر بعقائد الأزارقة إلى ذروته عندما تفرر الجماعات الغالية ومن سـار على دريهم أن الدار دار كفر (־) وتعلوهـا أحكام الكفر بنـاء على مـا فيها مـن

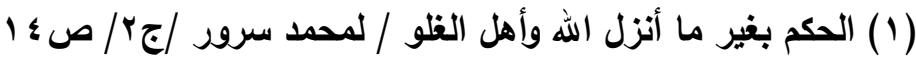

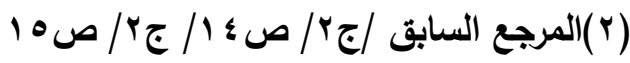

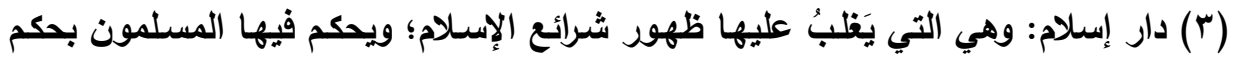
الإسلام وتعاليمه؛ وإن كان غالب سكان تلكان البلاد غير مسلمين.

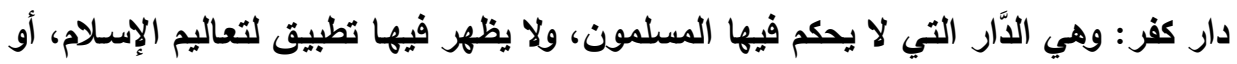

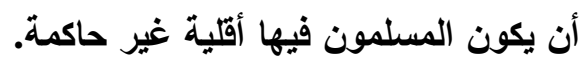
أما تعريف دار الحرب فقد اختلف فيه الفقهاء على رأيين: أحدهما أن دار الحرب هي الدار

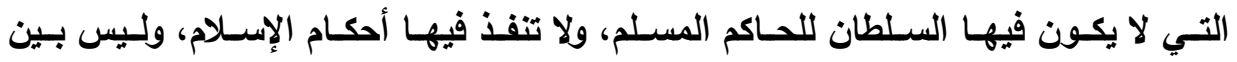

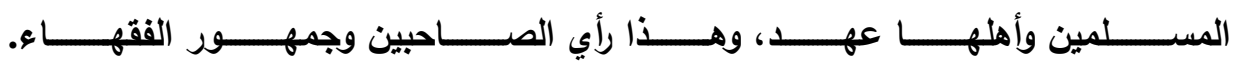

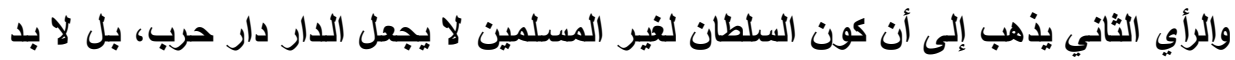

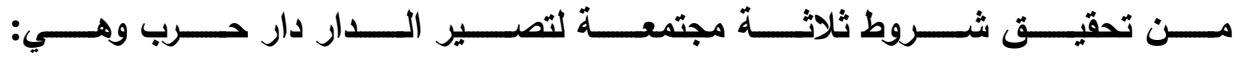

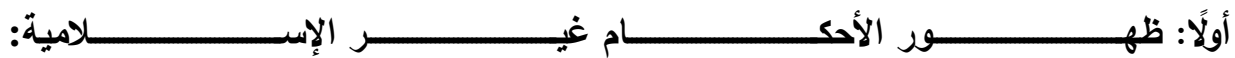
ثانيًا: أن يكون الإقليم متاخمًا للايار الإسلامية بحيث يتوقع منه الاعتداء على دار الإسلام .

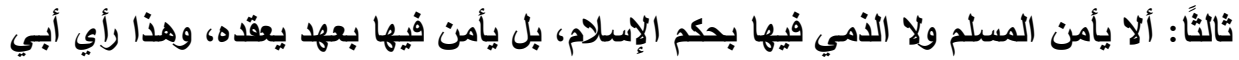
حنيفة والزيدية ويعض الفقهاء انظر العلاقات الدولية في الإسـلام، للشيخ محمد أبو زهرة: ص به م، طبع بالقاهرة

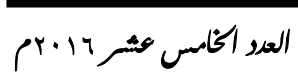

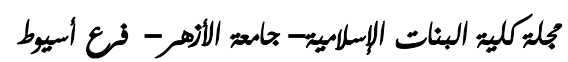


خروج على شـرع الله تعـالى (1) فيقولـون: " إذا ثبت أن مـا يجري في الديار

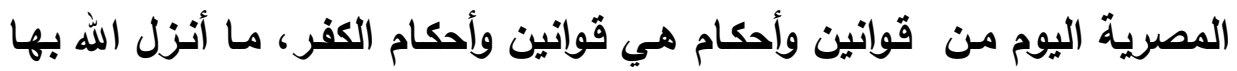

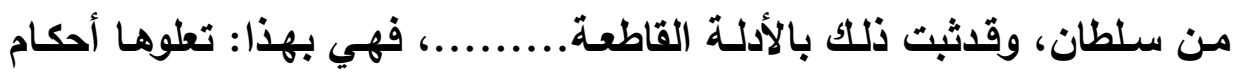

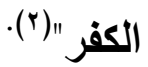

وذكر أحد الباحثين أن من مخالفات "داعش " في سـوريا الظلو في إطلاق

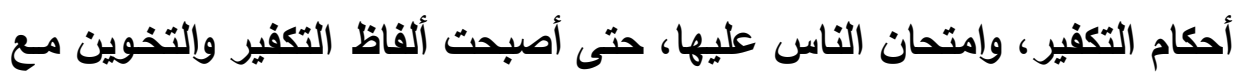

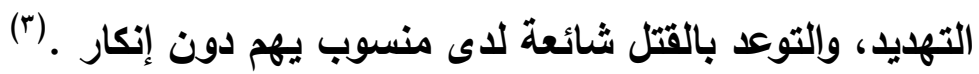

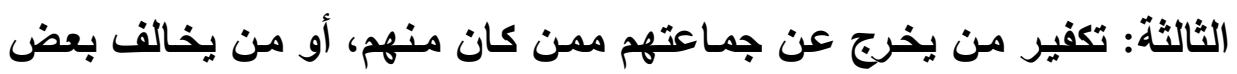

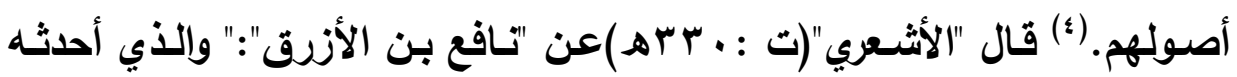

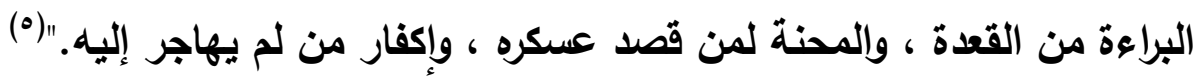

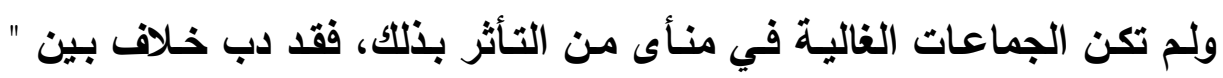
شكري مصطفى وأتباعه حيث لم يستطع بعض رفاق شكري مصطفى الصبر

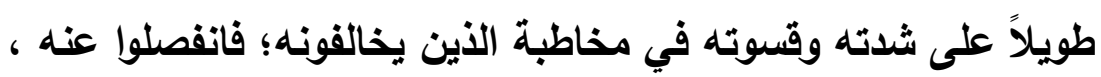
وأعلنوا أنهم لا يكفرون الذين لا يؤمنون بأفكارهم. ولم يتردد شكري ومن فئه معائه

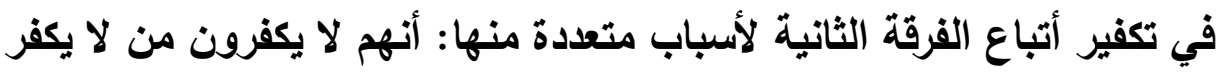

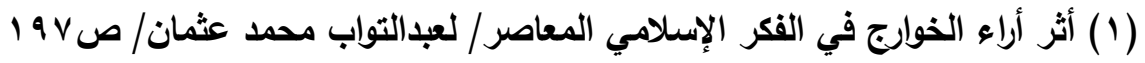

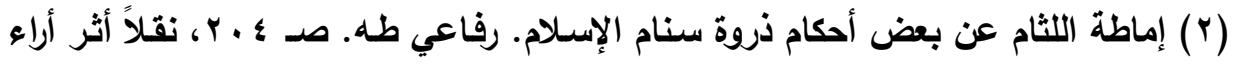

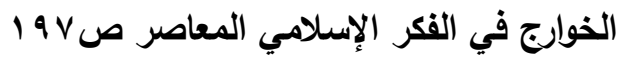

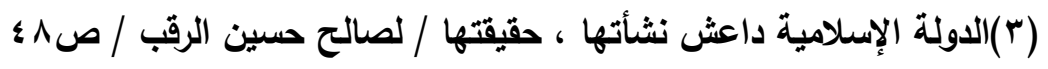

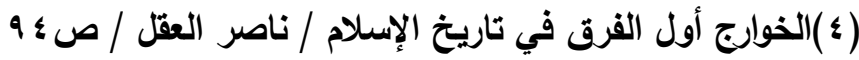

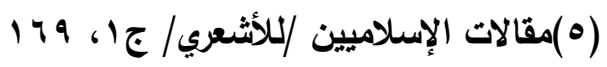

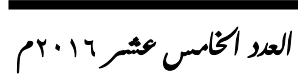

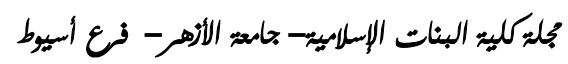


(الكافز • (1)

وأطلقت " داعش" (ז)عنان التأثر بفكر الأزارقة ؛ إذ أنهم " قد كفروا عباد الله،

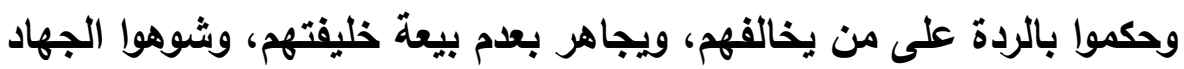

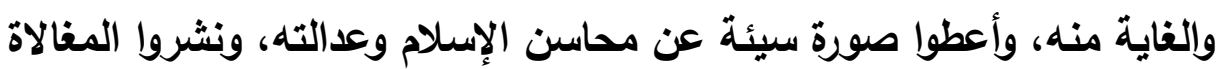

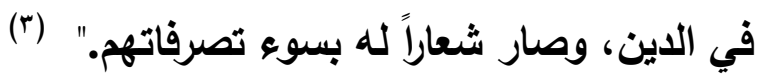

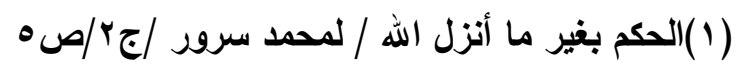

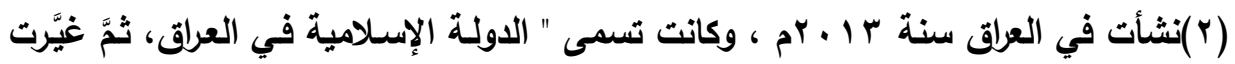
اسمها لتصبح الدولة الإسلامية في العرلق ويلاد

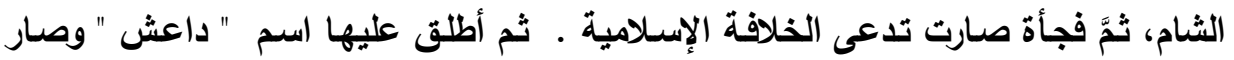

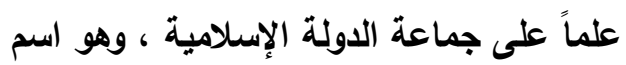
مختصر لها ، وذلك بأخذ الحرف الأول من كل كلمة ـ ـ نظر : الأولة الإسلامية "داعش"تثأتها

$$
\begin{aligned}
& \text { - حقيقتها - أفكارها - وموقف أهل العلم } \\
& \text { منها/ لصالح حسين الرقب }
\end{aligned}
$$

\begin{tabular}{|c|c|}
\hline 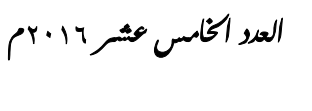 & جليكليي: البنات الإسالميي- جامع: الأهر- فع أسيوط \\
\hline
\end{tabular}

(ץ)(الدولة الإسلامية داعش نثأتها ، حقيقتها / لصايح حسين الرقب / صه الرة 


\section{الإلب الثاني \\ استملال الدماء والأموال والأمراض}

تكمـن خطـورة فكر الأزارقة فـي اسـتحلاله دمـاء المسـلمين الـذين لا يؤمنـون بفكرهم، ولذا فالكل في نظرهم كفار، تستباح دماؤهم وأموالهم وأعراضهم . أفرط الأزارقة في إطلاق أحكام الكفر على المجتمع وأفراده ،وينـاء على هذا الافراط طبقوا أمرين الأول : الاستعراض للمخالف . الثاني : استحلال دماء وأموال المخالقين. فقد كان الأزارقة لا يتعاملون إلا بمنهج القتل ، لذا عاثوا في الأرض الفسـاد، وروعوا الناس ،ووضعوا فيهم السيوف ، واستحلوا دمـاءهم وأموالهم . (') وقتلوا "عبدالله بن خباب بن الأرت" بعد أن أعطوه الأمان ويقروا بطن زوجته ، وتورعوا في قتل الأمي(؟) يقول شيخ الإسـلام " ابن تيميـة " في وصف الخوارج :" وَلَكَهْم

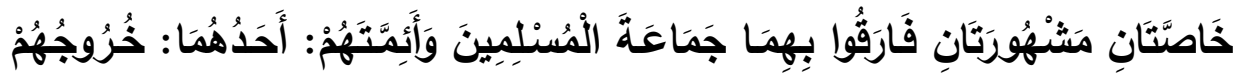

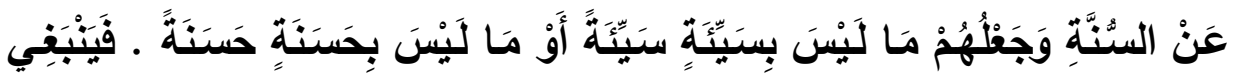

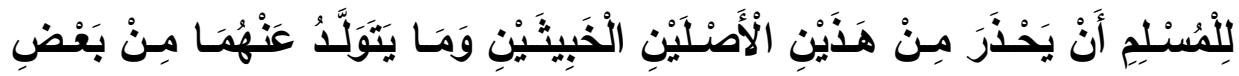

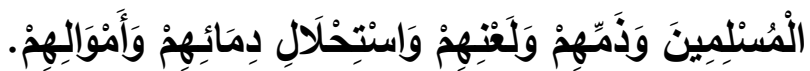

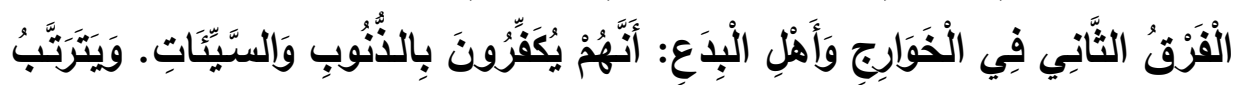

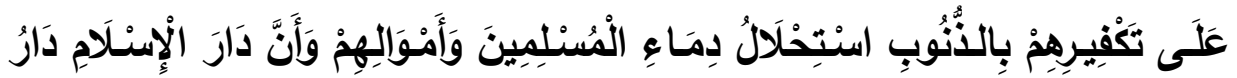

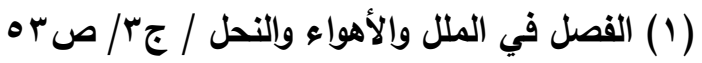

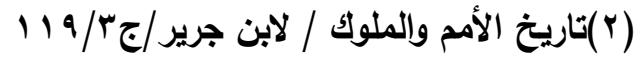

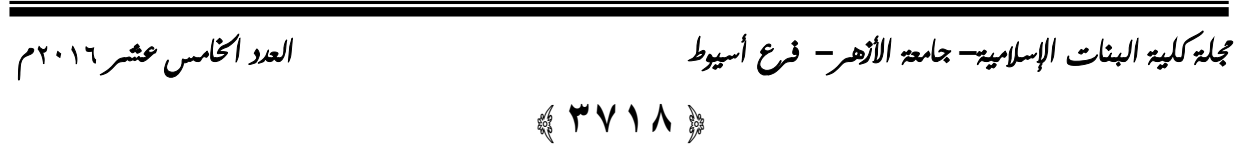




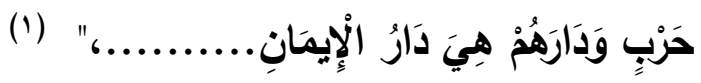
وقد تلقف الجهلة في العصر الحديث - ممن لا يرحون لله وقارًا ، ولا للإسدلام عزة وانتصارًا هذا المعتقد الفاسد ، والمسلك المنحرف عن الأزارقة فاستحلوا دماء الناس وأموالهم بناء على تكفير المجتمع وقالوا : إن الكافر أصل الحكم

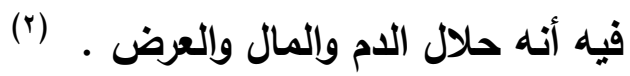
ويبين شكري مصطفى منهج جماعة التكفير في الاستحلال فيقول: "والإصرار على المعصية هو نية عدم التويـة منها، وإظهار ذلك هو إعلان نية ألا يتوب قولاًا أو فعلاً، وهذا كفر صريح في اعتبار الجماعة المسلمة يقتضي فلق هوته الهام وقطع الرقاب، فكل من أظهر إصراراً على معصية بينـة من معاصسي الله بقول أو فعل فإن للجماعة المسلمة حرية أن تستأصله منها وتطهر نفسها منسه

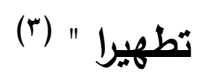

وقد طبق بعض الغلاة في العصر الحديث فكر الأزارقة في الاستحلال، واعتبروه

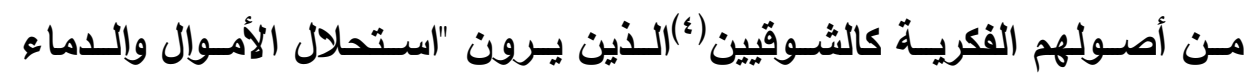
والأعـراض باعتبـار أن المجتمـع كـافر، ويـرون تصـفية المنشـقين باعتبـارهم

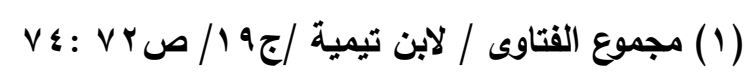

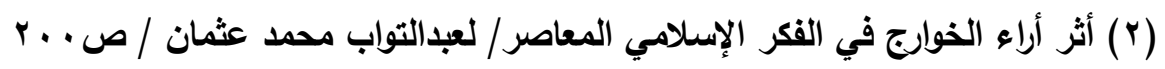

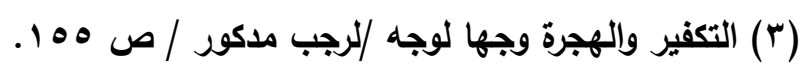

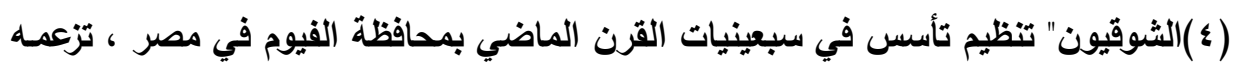
رجل يدعى شوقي الشيخ ،وقد ارتكز فكرهم علي

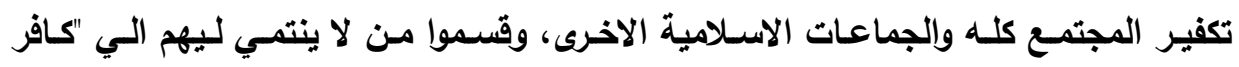

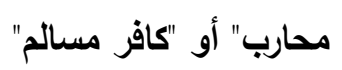

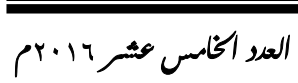

مجليكليي: البنات الإسلميت- جامع: الأهر- في أسيوط 


\section{خارجين عن الجماعة " (1). - (1)}

وعلى خطى الأزارقة سارت "داعش "فأوغلوا في القتل، وسفك الدماء ،واستحلال الأموال والأعراض ، وهذا يظهر من أمرين :

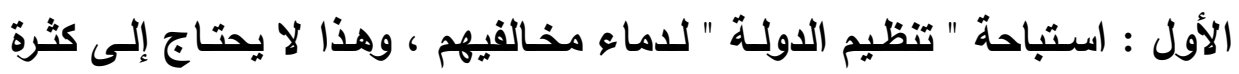

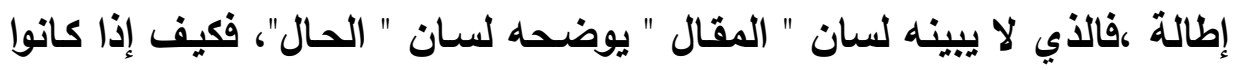

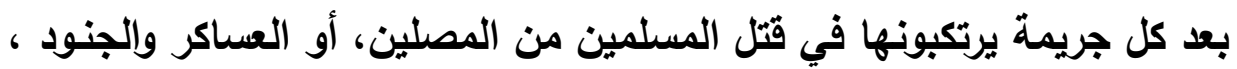
أو الأقارب يكتبون البيانات التي يتبنون فيها هذه العمليات ، ويفخرون بها بقلوب باردة ، ويسمون قتلاهم بـ" المرتدين" ، ويجطلون ذلكك باباً من أبواب

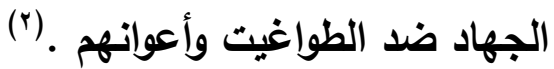
الثاني : أن جماعة الدولة سلبت الناس أموالهم وبيوتهم، وسرقت أموال الثهات الأمسة،

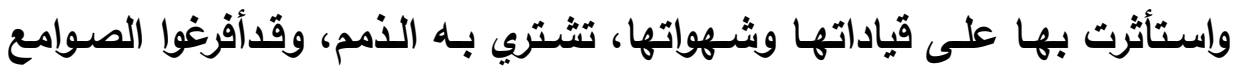
والمعامل وياعوها، في الوقت الذي يعاني فيها لناس من الجوع، ولم يكتفوا بذلك

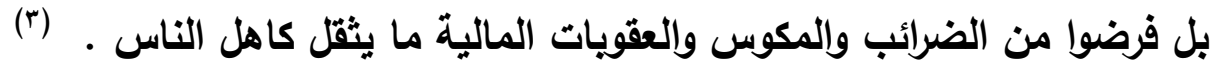

$$
\text { ومن خلال دراستنا لهذا المبحث نقرر ما يلي : }
$$

أولاً : أن فكر الخوارج كان ولا يزال أحد الينابيع التي يستمد منها كثير من آلهاء آلهاء

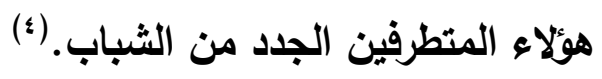

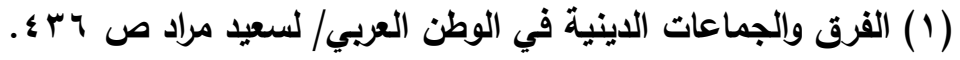

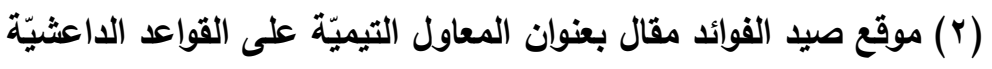

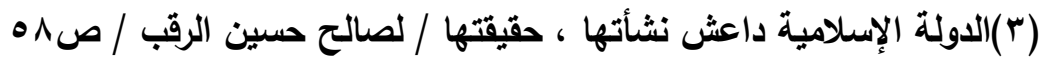

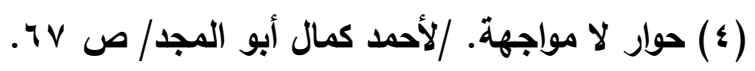

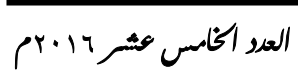

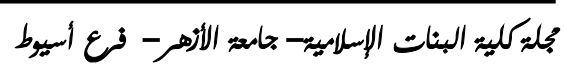
(TVY. 
ثانياً : ومـن هذا المنطلق لا يعدو أن يكون التكفير في العصر الحديث إلا انبعاثا للفكر القديم في صورة جديدة تتناسب مع العصر ، حركتها ظروف وعوامل متضافرة . ثالثاً : أن ثمـة ارتباط وثيق بـين الجماعات الغاليـة في العصر الحديث ويبين

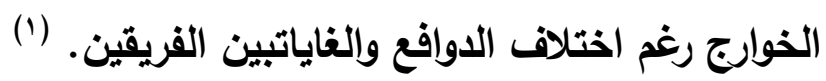

(1 (1) دراسة عن الفرق في تاريخ المسلمين. أحمد محمد جلي ص 1 ـ 1.

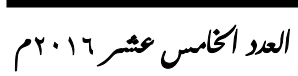

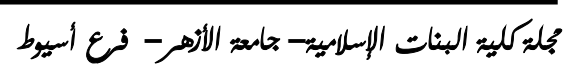
(4VY) 


\section{الخاتمة}

يمكن إبراز أهم ما توصل إليه البحث من نتائج فيما يلي :

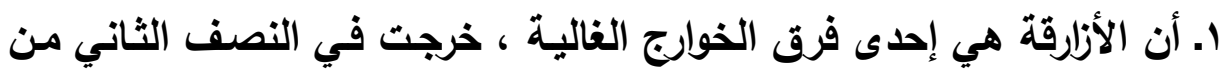

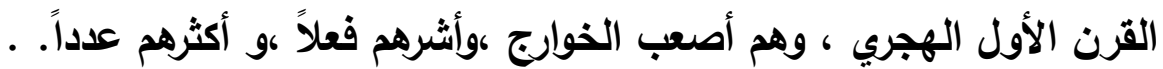

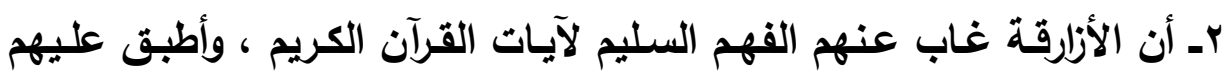

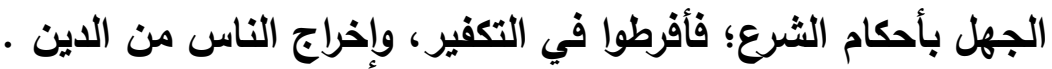

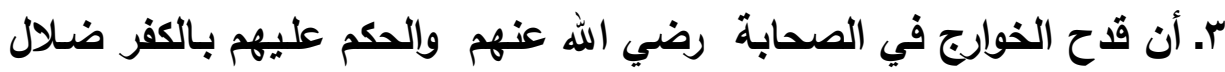
ويهتان، واضح بطلانه كـ أن أهل البدع يبتدعون البدعة ، ويكفرون من خالفهم فيها ، ويستحلون

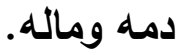
هـ أن الأزارقة رتبوا على قولهم بتكفير مرتكب الكبيرة استحلال دمـاء وأموال المخالفين؛ لأنهم يعتبرون ديارهم دار كفر.

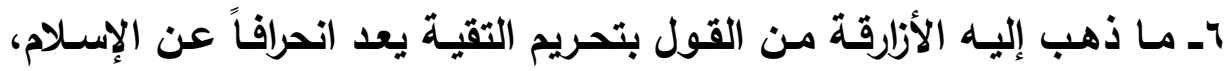
ومخالفاً للفطرة.

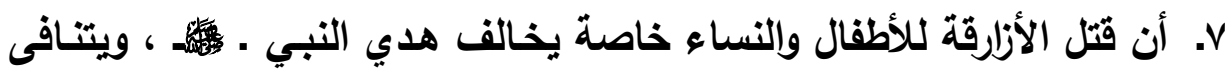

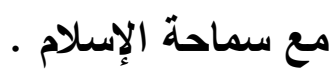
^ـ أن الغلاة في العصر الحديث التخذوا هذه البداع مرتكزات فكريـة لهم ، وأصولاً اعتقادية بنوا عليها نظرتهم للفرد والمجتمع .

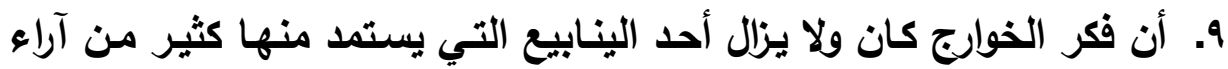

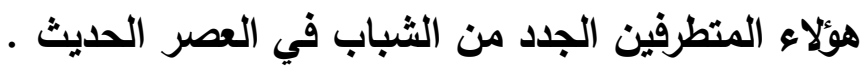

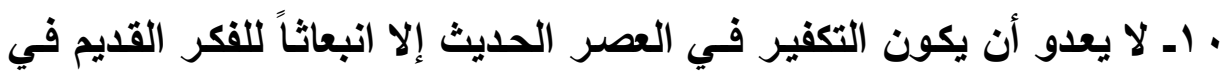
صورة جديدة تتناسب مع العصر، حركتها ظروف وعوامل متضافرة . 
1 أـ أن ثــة ارتبـاط وثيق بين الجماعـات الغاليـة في العصر الحـيث ويبين الخوارج رغم اختلاف الدوافع والغايات بين الفريقين. التوصيات :

1- الاهتمـام بمعرفة الروافـد الفكريـة للفـلاة الجدد لبيـان أن تلكك الأفكار التـي ترسخت لايهم تتنافي مع حقيقة الدين ومع جوهر الإسلام

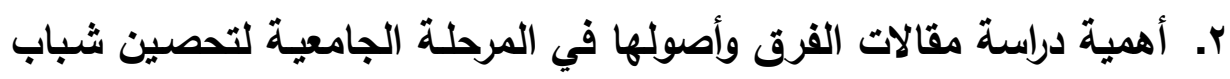

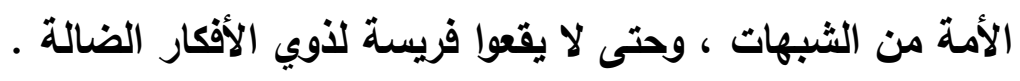




\section{فهرس المسادر والمراجع}

1 ـ أثر آراء الخوارج في الفكر الإسـلامي المعاصر ، عبدالتواب محمد عثمان

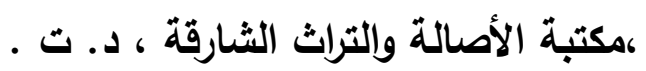

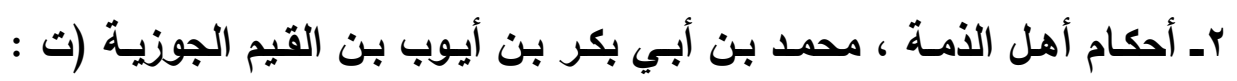
1

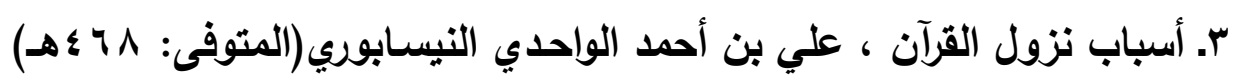

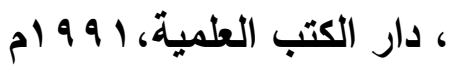

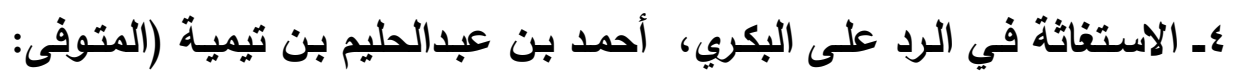

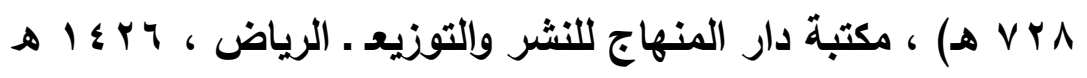

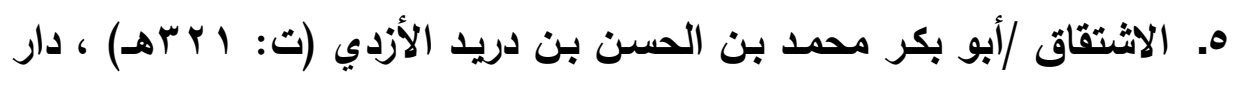

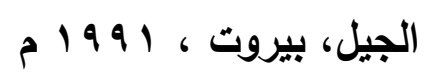

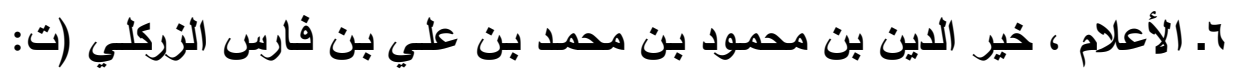

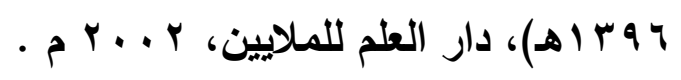

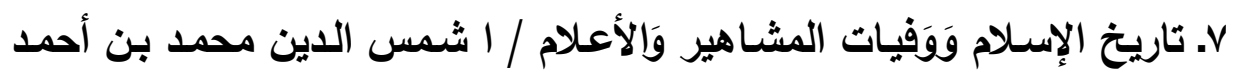

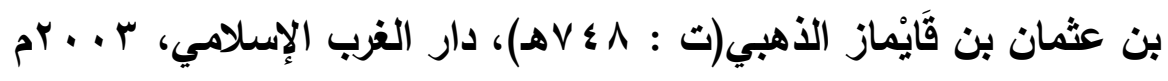

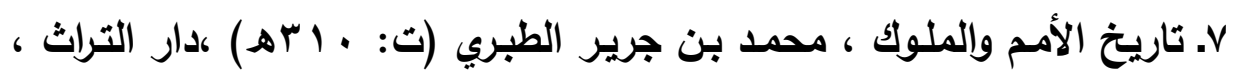
. I I R N v A. تاريخ دمثق / بن عساكر علي بن الحسن بن هبة الله (ت: الVهـ) ، دار

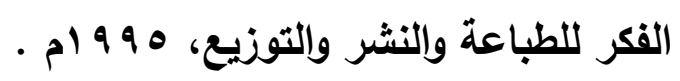

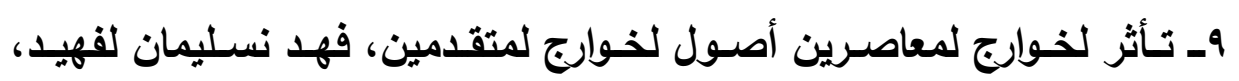
الرياض ، 4ب ؛ الهـ ـ التبصير في الدين وتمييز الفرقة الناجية عن الفرق الهالكين ، طاهر بن

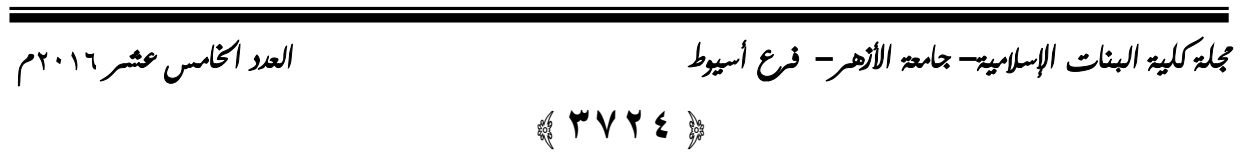




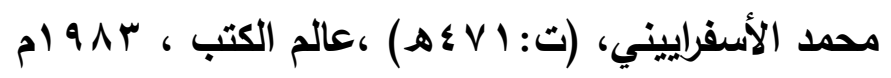
ا ـ تفسير آيـات الأحكام / محمد علي السـايس / المكتبة العصرية للطباعة

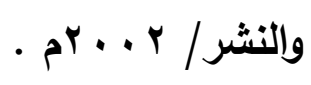

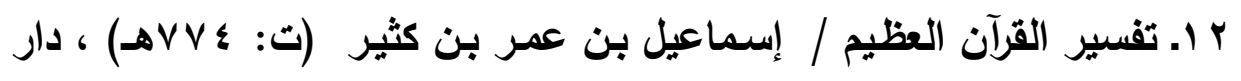

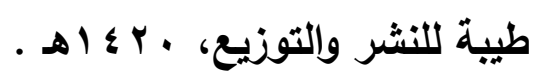
r اـ التقية عند الثيعة والخوارج ، أنس أحمد كرزون ، رسـالة علمية- جامعة اهنة

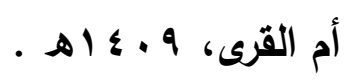
ع اـ التكفير والهجرة وجهاً لوجه، رجب مدكور، مكتبة الدين القيم، د. ت . .

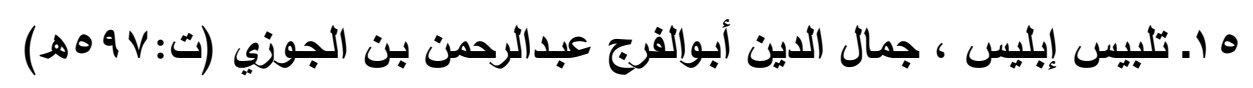
، دار القلم، 7 اــ التمهيد لمـا في الموطأ من المعاني والأسـانيا ، يوسف بن عبد الله بن محمد بن عبد البر (المتوفى:

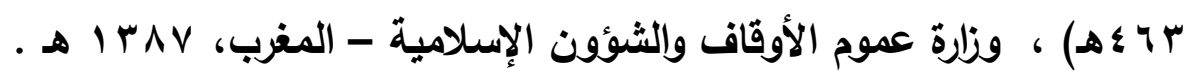

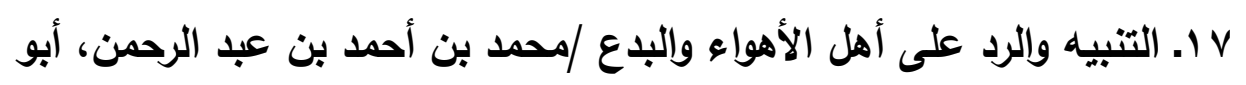

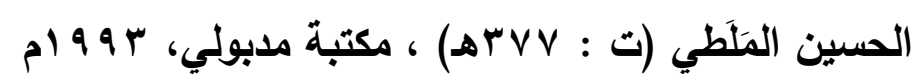

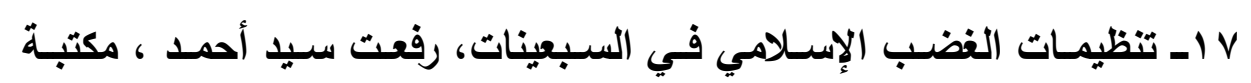

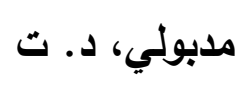

9 ا. جامع البيان في تأويل آي القرآنمحمد بن جرير الطبري (ت: اسهـ)، دار هجر للطباعة والنشر، د.ت • . . . الحكم بغير مـا أنزل الله وأهل الغلو، محمد سرور زين العابدين ، دار

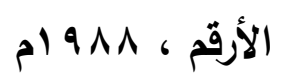

ا r. الخوارج الأصول التاريخية لمسألة تكفير المسلم. ، مصطفى حلمي ،مطبعة

مجليكليت البنات الإسلاميت- جامع: الأهر- فوع أسيوط




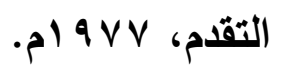

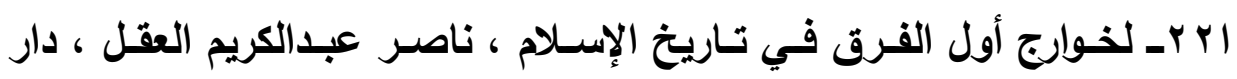

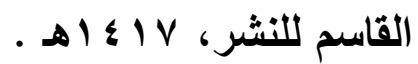
r r. الخوارج تاريخهم وآراؤهم الاعتقادية وموقف الإسـلام منها، غالب عواجي،

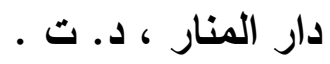
ع r. الخوارج والمرجئة ،محمد إبراهيم الفيومي ، دار الفكر العربي، ب \& أهـ.

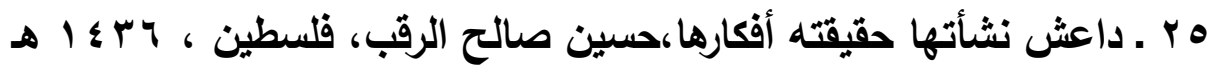
צ rـ دراسـة عن الفرق في تـاريخ المسلمين ، أحمد محمد أحمد جلي ،مركز

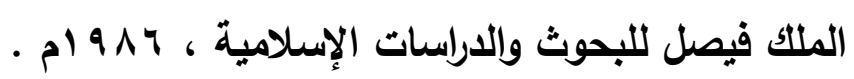
V r. الأخيرة في محاسن أهل الجزيرة، علي بن بسـام الشنتريني (ت: ب ؛ هـ)،

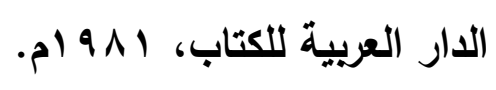
^ ץـ سير أعلام النبلاء، شـس الدين محمد بن أحمد بن عثمـان بن قَايْمـاز

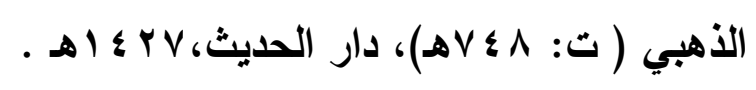

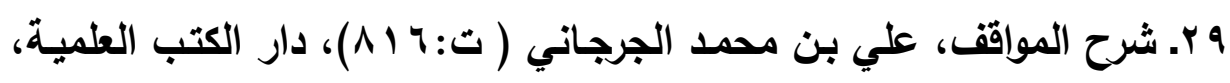
د. ت .

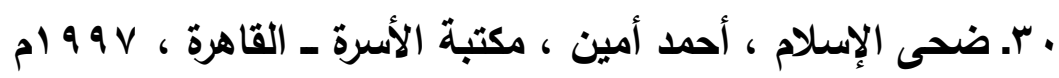

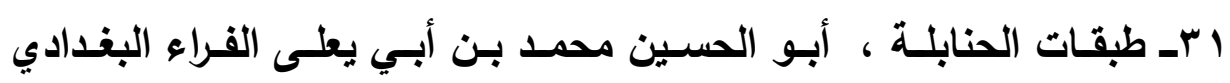

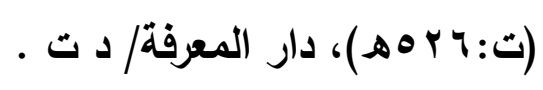

r r. طريق الهجرتين وياب السعادتين، محمد بن أبي بكر بن أيوب بن القيم

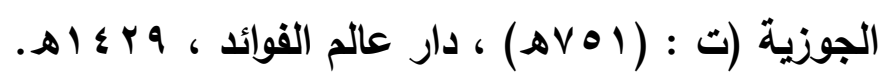

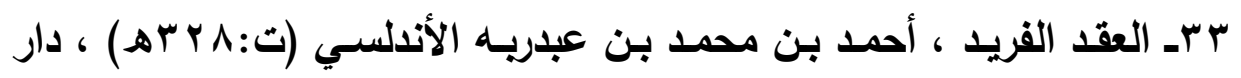

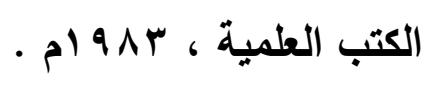

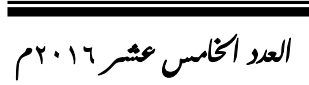
مجلةكليي: البنات الإسلميت- جامع: الأهر- فع أسيوط 
ع س. عقيدة أهل السنة والجماعة في الصحابة الكرام ، ناصر بن علي عائض

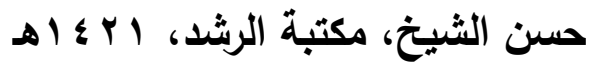
ه rـ الغلو في الدين في حياة المسلمين المعاصرين ، عبدالرحمن اللويحق ،

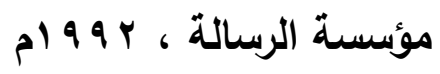
צ س. الفرق بين الفرق ، وييان الفرقة الناجية منهم ، أبو منصور عبد القاهر

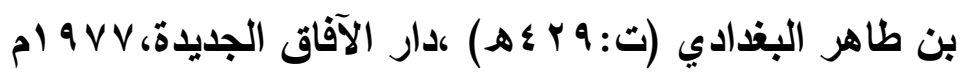
الفرق الكلامية الإسلامية مدخل ودراسة، علي عبدالفتاح مغربي، مكتبة وهبة ، - 1990

Vr. الفصل في الملل والأهواء والنحل ، علي بن أحمد بن حزم ( ت: جه ؛هـ)

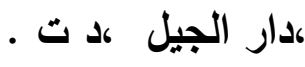
^ זـ الكامل في التاريخ ، محمد بن محمد بن عبدالكريم بن الأثير الثيباني

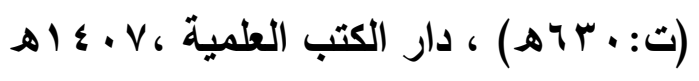

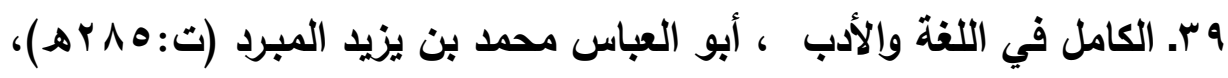
وزارة الشئون الإسلامية والأوقاف والاعوة والإرشـاد ، المملكة العربية السعودية ، د. ت

• ع. لسان الميزان ،أحمد بن علي بن محمد بن أحمد بن حجر العسقلاني (ت :

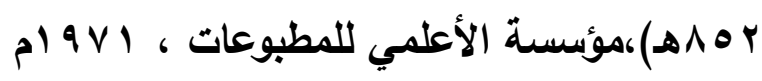

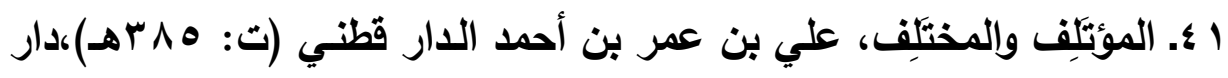
الغرب الإسدلامي 91919 ب عـ المبهج في تفسير أسـماء شـعراء ديوان الحماسـة، أبو الفتح عثمـان بن

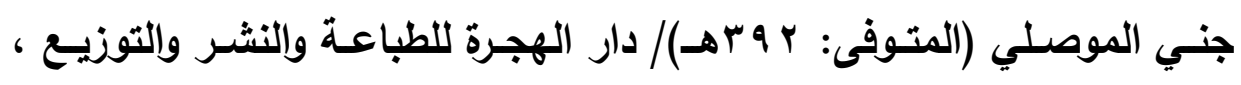
. $1 \leqslant \cdot 1$

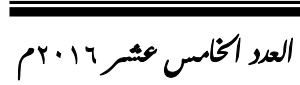
مجلةكليت البنات الإسلميت- جامعة الأهر- في أسيوط PVTV 


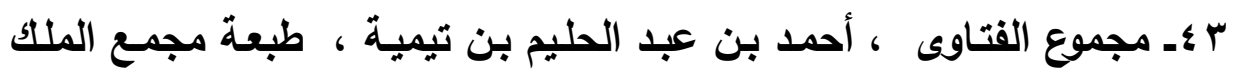

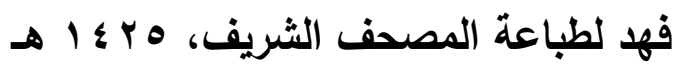

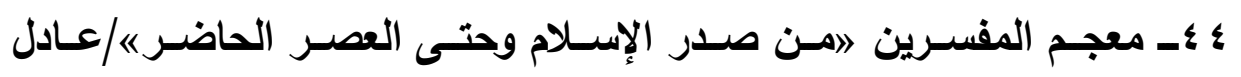

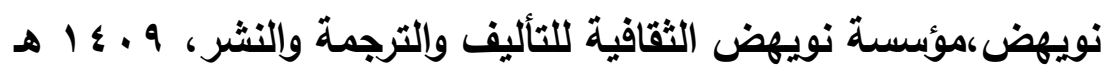

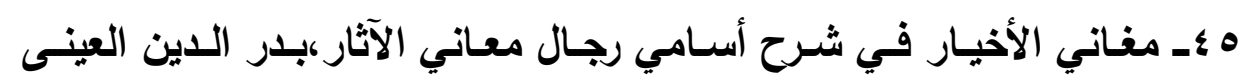

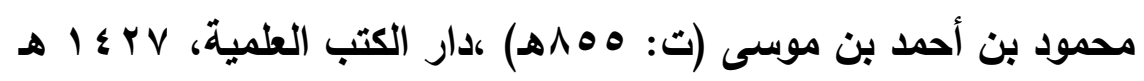

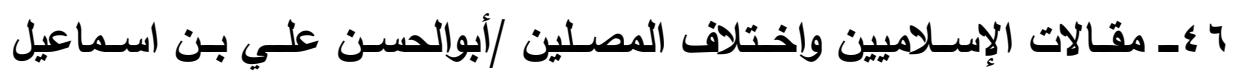

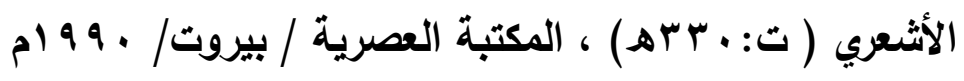

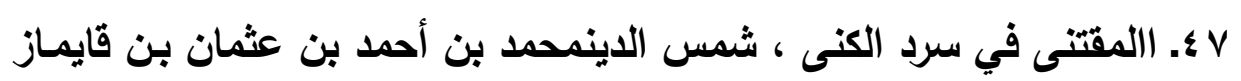

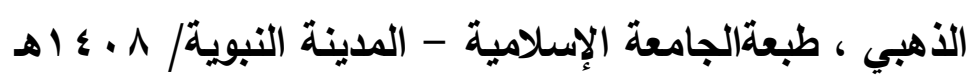

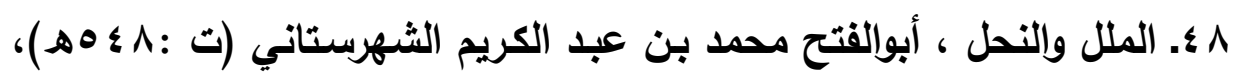

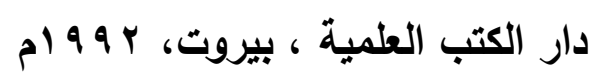

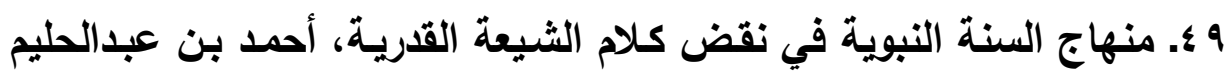

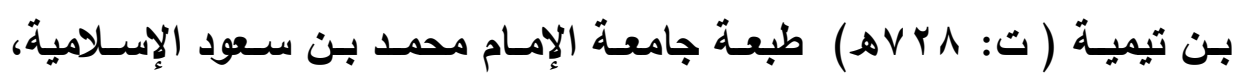

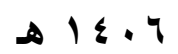

